Prepared for the U.S. Department of Energy

under Contract DE-AC05-76RL01830

\title{
DuraLith Alkali-Aluminosilicate Geopolymer Waste Form Testing for Hanford Secondary Waste
}

\section{Final Report}

W Gong

W Lutze

IL Pegg

May 2011

\section{Pacific Northwest}

NATIONAL LABORATORY

Proudly Operated by Battelle Since 1965 


\title{
DISCLAIMER
}

This report was prepared as an account of work sponsored by an agency of the United States Government. Neither the United States Government nor any agency thereof, nor Battelle Memorial Institute, nor any of their employees, makes any warranty, express or implied, or assumes any legal liability or responsibility for the accuracy, completeness, or usefulness of any information, apparatus, product, or process disclosed, or represents that its use would not infringe privately owned rights. Reference herein to any specific commercial product, process, or service by trade name, trademark, manufacturer, or otherwise does not necessarily constitute or imply its endorsement, recommendation, or favoring by the United States Government or any agency thereof, or Battelle Memorial Institute. The views and opinions of authors expressed herein do not necessarily state or reflect those of the United States Government or any agency thereof.

\author{
PACIFIC NORTHWEST NATIONAL LABORATORY \\ operated by \\ BATTELLE \\ for the \\ UNITED STATES DEPARTMENT OF ENERGY \\ under Contract DE-AC05-76RL01830
}

\author{
Printed in the United States of America \\ Available to DOE and DOE contractors from the \\ Office of Scientific and Technical Information, \\ P.O. Box 62, Oak Ridge, TN 37831-0062; \\ ph: (865) 576-8401 \\ fax: $(865) 576-5728$ \\ email: reports@adonis.osti.gov
}

Available to the public from the National Technical Information Service

5301 Shawnee Rd., Alexandria, VA 22312

ph: (800) 553-NTIS (6847)

email: $\underline{\text { orders@ntis.gov }<h t t p: / / w w w . n t i s . g o v / a b o u t / f o r m . a s p x ~}>$

Online ordering: http://www.ntis.gov

This document was printed on recycled paper. 
VSL-10R2140-1

PNNL-20565

\section{Final Report}

DuraLith Alkali-Aluminosilicate Geopolymer Waste Form Testing for Hanford Secondary Waste

prepared by

Weiliang Gong, Werner Lutze, and Ian L. Pegg

Vitreous State Laboratory

The Catholic University of America

Washington, DC 20064

for

Pacific Northwest National Laboratory

Richland, WA 99352

December 17, 2010

Rev. 1, 5/10/11 


\section{Table of Contents}

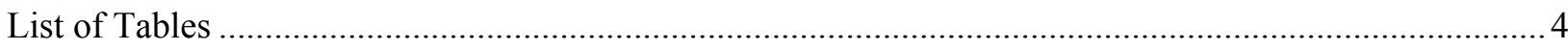

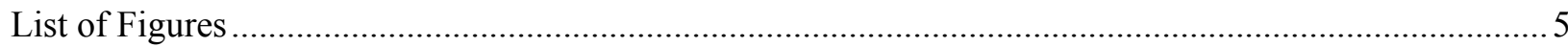

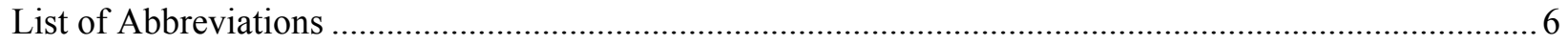

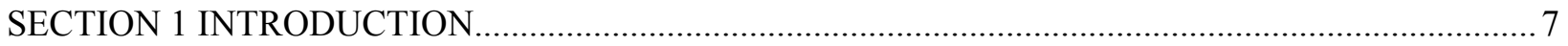

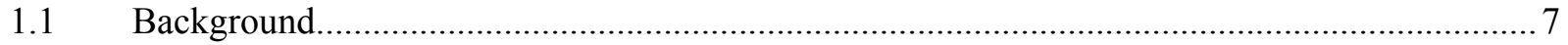

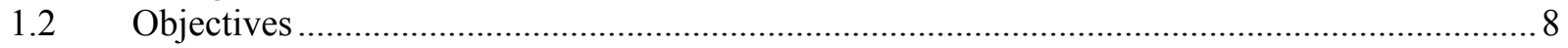

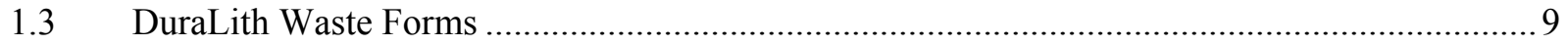

SECTION 2 WASTE SIMULANT COMPOSITION AND PREPARATION ………………………….... 10

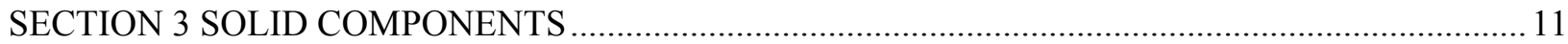

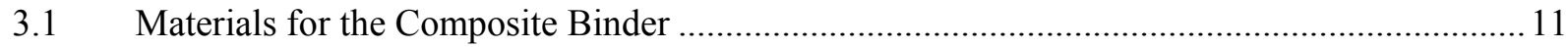

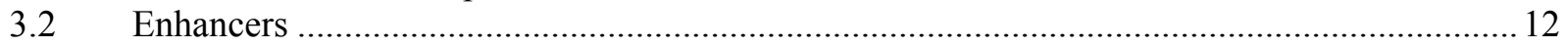

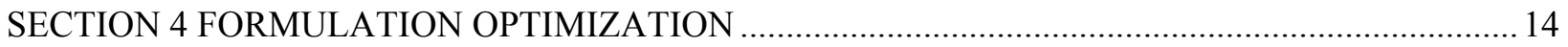

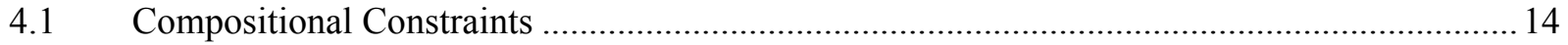

4.2 Optimizing Products within the Ranges of Compositional Constraints .....................................15

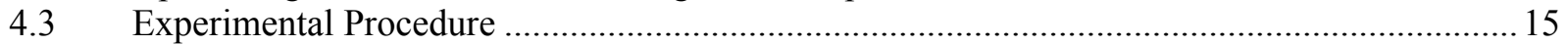

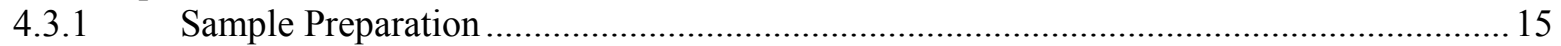

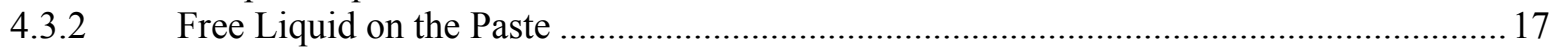

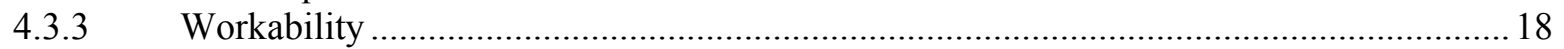

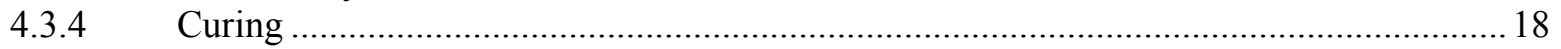

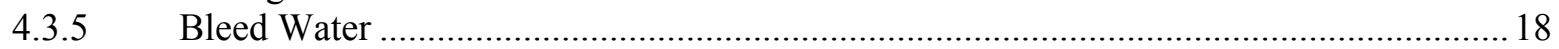

4.3.6 Surface Deposits, Cracks, Shrinkage, and Swelling ........................................................ 19

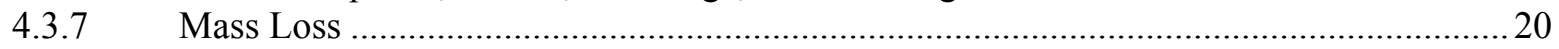

4.3.8 Free Liquid in Cured Samples .............................................................................22

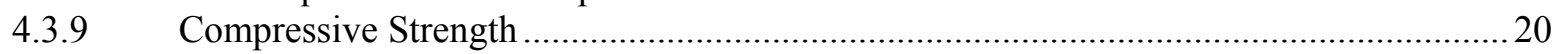

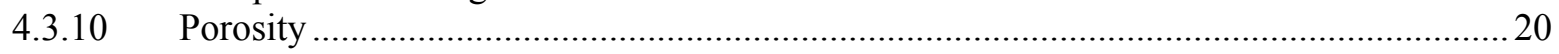

4.3.11 Toxicity Characteristic Leaching Procedure (TCLP) …………………………….......2.

4.3.12 ANSI/ANS-16.1 Leaching Test .....................................................................................2

4.3.13 Heat Generation (Activator and Paste) …………….................................................2.

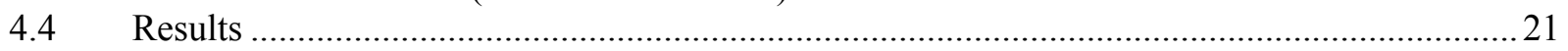

4.4.1 DuraLith for Waste Simulant S1 (Water Optimization) …………………………...........22

4.4.2 DuraLith for Waste Simulants S2 to S4 …………………………………………......2

4.4.3 DuraLith with Combinations of Enhancers .................................................................2 24

4.4.4 DuraLith Variation Tests (Robustness) ……………………………………………....2 24

4.4.5 DuraLith Formulations with Increased Waste Loading ………………………………...... 24

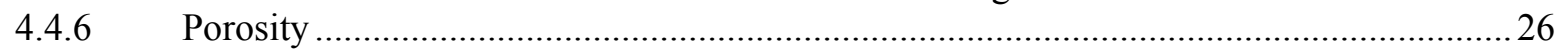

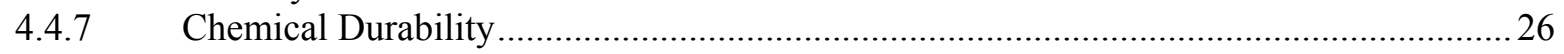

4.4.8 Free Liquid in Cured Samples ................................................................................

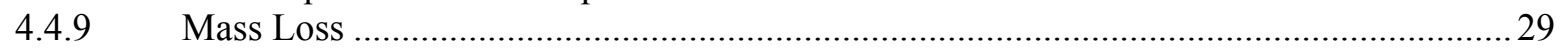

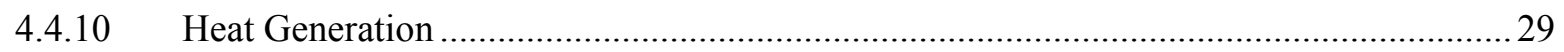

SECTION 5 PRODUCTS RECOMMENED FOR SCALE-UP TESTING …………………………......... 33

$5.1 \quad$ Selection Criteria ……………………………………………………………………. 33

5.2 Recipe for the Recommended Product ..................................................................................... 35 
The Catholic University of America

Vitreous State Laboratory
DuraLith Geopolymer Testing for Hanford Secondary Waste

Final Report, VSL-10R2140-1, Rev. 1

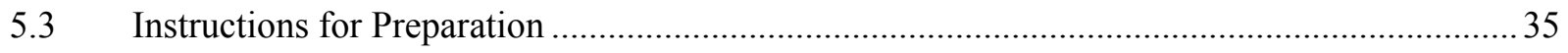

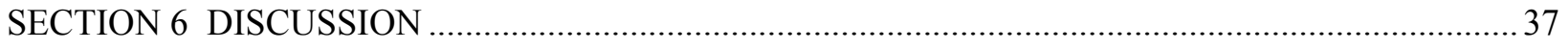

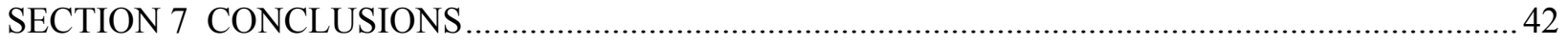

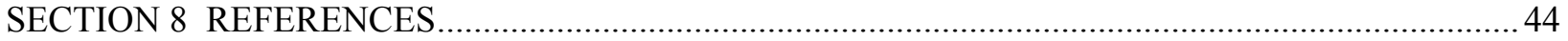




\section{List of Tables}

Table 2.1

Table 2.2

Table 2.3

Table 2.4

Table 2.5

Table 2.6

Table 2.7

Table 2.8

Table 3.1

Table 3.2

Table 3.3

Table 4.1

Table 4.2

Table 4.3

Table 4.4

Table 4.5

Table 4.6

Table 4.7

Table 4.8

Table 4.9

Table 4.10

Table 4.11

Table 4.12

Table 4.13

Table 4.14

Table 4.15

Table 4.16

Table 4.17

Table 4.18

Table 4.19

Table 4.20

Table 4.21

Table 4.22

Table 4.23a

Table 4.23b

Table 4.24

Table 5.1

Table 5.2

Table 5.3
Hanford Secondary Waste Composition (Moles/Liter).

$\mathrm{T}-1$

Chemicals and Masses for 15 liters HSW S1 Simulant (2 M Na).

$\mathrm{T}-2$

Chemicals and Masses for 10 liters HSW S1 Simulant (8 M Na).

$\mathrm{T}-3$

Chemicals and Masses for 5 liters HSW S1 Simulant (12 M Na).

$\mathrm{T}-4$

Chemicals and Masses for 15 liters HSW S2 Simulant (2 M Na).

$\mathrm{T}-5$

T-6

$\mathrm{T}-7$

T-8

$\mathrm{T}-9$

$\mathrm{T}-10$

$\mathrm{T}-11$

$\mathrm{T}-12$

Constraints for Optimization of Binder and Activator Compositions.

$\mathrm{T}-13$

Compositions of DuraLith Products for Waste Simulants S2,

S3, S4 (all $2 \mathrm{M} \mathrm{Na}$ ) (wt\%).

$\mathrm{T}-14$

$\mathrm{T}-15$

$\mathrm{T}-16$

Properties of DuraLith Pastes and Products for Wastes S2, S3, S4.

Compositions of DuraLith Products with Combinations of Enhancers

$\mathrm{T}-17$

and Other Additives (Waste S1) - Wt\%

Properties of DuraLith Pastes and Products with Combinations

$\mathrm{T}-18$

of Enhancers and Other Additives (S1).

DuraLith Composition Variations (Robustness Tests) (wt\%).

$\mathrm{T}-19$

$\mathrm{T}-20$

$\mathrm{T}-21$

$\mathrm{T}-22$

$\mathrm{T}-23$

Compositions of Durath Product with Higher Wast Loading (S4) (W

Properties of DuraLith Product Compositions with Higher Waste Loading (S4).

$\mathrm{T}-23$

TCLP Results (Hazardous Elements, $\mathrm{Cu}$, and $\mathrm{Sn}, \mathrm{mg} / \mathrm{L}$ ) in DuraLith Products for T-24

Water Optimization (Waste S1, 2M Na)

TCLP Results (Hazardous Elem
(Wastes S2-, S3-, S4, 2 M Na).

$\mathrm{T}-25$

TCLP Results (Hazardous Elements, $\mathrm{Cu}$, and $\mathrm{Sn}, \mathrm{mg} / \mathrm{L}$ ) in DuraLith Products with T-26 Combinations of Enhancers and Other Additives (Waste S1, $2 \mathrm{M} \mathrm{Na}$ )

TCLP Results (Hazardous Elements, $\mathrm{Cu}$, and $\mathrm{Sn}, \mathrm{mg} / \mathrm{L}$ ) in DuraLith Products (Robustness Tests)

$\mathrm{T}-27$

$\mathrm{T}-28$

Higher Waste Loading (Waste S1).

TCLP Results for Re and I.

T-29

$\mathrm{T}-31$

$\mathrm{T}-32$

$\mathrm{T}-33$

$\mathrm{T}-34$

$\mathrm{T}-34$

$\mathrm{T}-35$

T-36

$\mathrm{T}-36$

$\mathrm{T}-37$ 


\section{List of Figures}

Figure 4.1 Ingredients for the Preparation of a DuraLith Product. $\quad$ F-1

Figure 4.2 Mixing the Dry Ingredients with a Hand-Held Mixer (EHR23). $\quad$ F-2

Figure 4.3 Pouring the Activator Solution into the Dry Binder Mix. $\quad$ F-3

$\begin{array}{lll}\text { Figure 4.4 Early Stage of Mixing Binder and Activator. } & \text { F-4 }\end{array}$

$\begin{array}{lll}\text { Figure 4.5 After a Few Minutes the Mix Becomes Fairly Dry. } & \text { F-5 }\end{array}$

Figure 4.6 The Dryness of the Mix Begins to Disappear After Two Minutes $\quad$ F-6

Figure 4.7 Within About Three Minutes the Paste Becomes Homogeneous. $\quad$ F-7

Figure 4.8 The Paste is Free of Lumps and Ready to Pour. $\quad$ F-8

Figure 4.9 Fresh Paste in 2" by 4" Plastic Moulds on a Vibrating Table F-9

Figure 4.10 Hardened DuraLith Samples After 24 Hours at Room Temperature. F-10

Figure 4.11 DuraLith Samples After Demoulding. $\quad$ F-11

Figure 4.12 Air Bubbles Shown on Sample Surfaces. $\quad$ F-12

Figure 4.13 Air Bubbles in a DuraLith Sample (SEM micrograph) F-13

Figure 4.14a Results of ANS 16.1 Leach Test for DuraLith Sample S1-2X13R2 $\quad$ F-14

Figure 4.14b Results of ANS 16.1 Leach Test for DuraLith Sample S1-2X14 F-15

Figure 4.15 Heat Generation in an Activator Solution (Temperature Curve). $\quad$ F-16

Figure 4.16 K-Lab Intensive Mixer From Lancaster Engineering (5-gal Pan). $\quad$ F-17

Figure 4.17 Pouring 2.5 gal DuraLith Paste. $\quad$ F-18

Figure 4.18 Container Holds 2.5 gal Fresh Paste and Thermocouples (Middle and Left) F-19

Figure 4.19 Container with 2.5 gal of Hardened Crack-Free Paste. $\quad$ F-20

Figure 4.20a Heat Generation in a Furnace Slag-Based Paste (Temperature Curve) F-21

Figure 4.20b Heat Generation in a Furnace Slag-Based Paste; first 500 minutes $\quad$ F-22 (Temperature Curve).

Figure 4.21a Heat Generation in a Metakaolin-Based Paste (Temperature Curve). F-23

Figure 4.21b Heat Generation in a Metakaolin-Based Paste; first 400 minutes
(Temperature Curve)

Figure 4.22 Heat Generation in a Furnace Slag-Based Paste; $6 \mathrm{M} \mathrm{Na}$ (Temperature Curve). F-25 


\section{List of Abbreviations}

AAS Alkali Alumino Silicate

Ag-Z IONEX Ag 900, a silver ion exchanged mordenite

BFS Blast Furnace Slag

$\mathrm{CSH}$ Calcium Silicate Hydrate

DCP-AES Direct Current Plasma - Atomic Emission Spectroscopy

DOE Department of Energy

EPA Environmental Protection Agency

ETF Effluent Treatment Facility

FS Furnace Slag

HEPA High Efficiency Particulate Air

HLW High-Level Waste

HSW Hanford Secondary Waste

IDF Integrated Disposal Facility

IHLW Immobilized HLW

ILAW Immobilized LAW

LAW Low-Activity Waste

MK Metakaolin

ND Not Determined

ORP Office of River Protection

PNNL Pacific Northwest National Laboratory

RCRA Resource Conservation and Recovery Act

SF Silica Fume

STU Solidification Treatment Unit

TCLP Toxicity Characteristic Leaching Procedure

VSL Vitreous State Laboratory

W/C Water-to-Cementitious Materials (Geopolymer Solids) Mass Ratio

WRPS Washington River Protection Solutions

WTP Hanford Tank Waste Treatment and Immobilization Plant

XRF X-Ray Fluorescence 


\section{SECTION 1 INTRODUCTION}

\subsection{Background}

The US Department of Energy (DOE), Office of River Protection (ORP), through its contractors, is constructing the Hanford Tank Waste Treatment and Immobilization Plant (WTP) to convert the radioactive and hazardous wastes into stable glass waste forms for disposal. Within the WTP, the pretreatment facility will receive the retrieved waste from the tank farms and separate it into two treated process streams. The pretreated high-level waste (HLW) mixture will be sent to the HLW vitrification facility, and the pretreated low-activity waste (LAW) stream will be sent to the LAW vitrification facility. The two WTP vitrification facilities will convert these process streams into glass, which will be poured directly into stainless steel canisters. The immobilized HLW (IHLW) canisters will ultimately be disposed of at an offsite federal repository. The immobilized LAW (ILAW) canisters will be disposed of onsite in the Integrated Disposal Facility (IDF).

In addition to the primary IHLW and ILAW glass waste forms, the processing of the tank wastes will generate secondary wastes, including routine solid wastes and liquid process effluents. Liquid wastes may include process condensates and liquids from the off-gas treatment systems. The liquid-effluent secondary wastes will be sent to the Effluent Treatment Facility (ETF) for further treatment and solidification before disposal at the IDF.

The ETF is a Resource Conservation and Recovery Act (RCRA)-permitted multi-waste treatment and storage unit that can accept dangerous, low-level, and mixed wastewaters for treatment. The ETF receives, treats, and disposes of liquid effluents from cleanup projects on the Hanford Site. It is planned to increase the capacity of the ETF to process the increased volume of secondary wastes when the WTP begins waste treatment and immobilization operations. A Solidification Treatment Unit (STU) will be added to the ETF to provide the needed additional capacity. Washington River Protection Solutions (WRPS) has been chartered to move forward with the design and construction of the STU for ETF. The STU needs to be operational by 2018 to receive secondary liquid wastes from the WTP.

The current baseline calls for solidification of the ETF evaporator concentrate in a cement-based waste form. However, alternative secondary waste forms are being considered. In 2006, Pacific Northwest National Laboratory (PNNL) completed for DOE an evaluation of three low-temperature technologies for the immobilization of mixed radioactive and hazardous waste [1]. That testing program showed that the DuraLith alkali-aluminosilicate geopolymer demonstrated potential as a waste form for the liquid secondary waste stream from WTP based on TCLP, compressive strength, and sodium leachability index requirements [1, 2]. Subsequently, to support the selection of a waste form for the liquid secondary wastes from WTP, WRPS initiated secondary waste form testing work at PNNL. In 2009, preliminary screening of waste forms was conducted to assess the viability of each for the solidification of the liquid secondary wastes. The candidate waste forms were prepared at PNNL using a

simulated secondary waste stream spiked with ${ }^{99} \mathrm{Tc}$ and stable iodine as iodide representing ${ }^{129} \mathrm{I}$. 
${ }^{99} \mathrm{Tc}$ is the primary radioactive constituent of concern, whereas ${ }^{129} \mathrm{I}$ is of somewhat lesser concern. The RCRA elements are additional constituents of concern and their leachability also must be characterized as part of the disposal site licensing process. The results from that work showed that the DuraLith waste form continued to show promise [3]. However, it was also recognized that further work was needed to optimize performance and assess the robustness of this waste form. The present report presents the results from work that was conducted to address those needs, as described in an associated Test Plan [4].

Wastes intended for disposal in the IDF must meet requirements of DOE Order 435.1 and permit requirements established by the Washington State Department of Ecology. These requirements are captured in the waste acceptance criteria for IDF. Included are criteria with respect to free liquids, compliance with land disposal restrictions, compressive strength, and leachability. For the purposes of the development and optimization work described in the present report, the following requirements applied:

- Land Disposal Restrictions: The waste form will meet the land disposal requirements in 40 CFR 268 by meeting the universal treatments standards in 40 CFR 268.48 via the TCLP test.

- Free Liquids: The waste form shall contain no detectable free liquids as defined in SW-846 Method 9095.

- Leachability Index: The waste form shall have a sodium leachability index greater than 6.0 when tested in deionized water using the ANSI/ANS-16.1 or EPA Method 1315 Method. The waste form shall have a rhenium or technetium leachability index greater than 9.0 .

- Compressive Strength: The compressive strength of the waste form shall be at least 3.54E6 Pa (500 psi) when tested in accordance with ASTM C39/C39M.

\subsection{Objectives}

The primary objective of the work reported here was to develop additional information regarding the DuraLith alkali aluminosilicate geopolymer as a waste form for liquid secondary waste to support selection of a final waste form for the WTP secondary liquid wastes to be disposed in the IDF. Testing focused on optimizing waste loading, improving waste form performance, and evaluating the robustness of the waste form with respect to waste variability. In particular, the testing included:

- Optimization of the water content in the DuraLith paste

- Optimization of the quantities of binder materials to improve waste loading

- Evaluation of the sensitivity of the waste form to

o Waste-stream composition variability

o Waste-stream concentration ranges

o Process upsets such as variation in waste-to-binder ratios and variation in dry binder materials ratios 
o Curing time, workability, compressive strength, and leach resistance

- Tests with other binder materials that may be less costly

- Waste form porosity control during fabrication

- Measurement of heat generation for the waste form solidification step and precursor preparation

\subsection{DuraLith Waste Forms}

The DuraLith waste form is based on generic geopolymer chemistry as described in a previous report [2] and references therein. A geopolymer is an inorganic polymer formed by poly-condensation, e.g., n[-O-Si-OH $+\mathrm{H}-\mathrm{O}-\mathrm{Al}-\mathrm{O}-]=[-\mathrm{O}-\mathrm{Si}-\mathrm{O}-\mathrm{Al}-\mathrm{O}-]_{\mathrm{n}}+\mathrm{nH}_{2} \mathrm{O}$. This type of chemical reaction takes place when a highly alkaline silicate solution is mixed with a reactive material such as metakaolin, which is dehydroxylated kaolin (kaolin: $\left.\mathrm{Al}_{2} \mathrm{Si}_{2} \mathrm{O}_{5}(\mathrm{OH})_{4}\right)$. In the case of DuraLith, the liquid phase is the (tailored) waste solution, which is then mixed with a variety of additives. The DuraLith composition can be adjusted and optimized for specific requirements of radioactive waste stabilization, specific ingredients that are employed, and specific additives that are used to enhance the immobilization of hazardous elements and radionuclides such as ${ }^{99} \mathrm{Tc}$ and ${ }^{129} \mathrm{I}$.

The liquid waste is tailored by adding sodium- and/or potassium hydroxide together with a rapidly dissolving form of silica, e.g., silica fume. We refer to this solution as the "activator." The activator is one of three components needed to make a DuraLith waste form. The second component is the "composite binder". This is a mixture of reactive, low-CaO aluminosilicates (e.g., metakaolin $\mathrm{Al}_{2} \mathrm{O}_{3} \cdot 2 \mathrm{SiO}_{2}$, fly ash Class $\mathrm{F}$ ) and high-CaO aluminosilicates (e.g., blast furnace slag, fly ash Class C). The third component, the "enhancer," is composed of selected additives that are used to enhance the fixation of key radionuclides such as ${ }^{99} \mathrm{Tc}$ and ${ }^{129} \mathrm{I}$. The preparation of a DuraLith waste form involves mixing of the binder with the activator, which can be done in the final waste form container but preferably in a mixing device prior to transferring the paste into the final waste form container.

In the present work, DuraLith samples were prepared in small batches (up to $20 \mathrm{~kg}$ ). After mixing, the paste is transferred into typically 2" by 4" cylindrical containers, which are opened and removed after 24 hours. The solid geopolymer samples are cured for 28 days at room temperature and then subjected to property measurements such as mechanical and chemical durability.

In our earlier testing with Hanford secondary waste [2], two formulations with the best performance in terms of mechanical and chemical durability, TB6 and TB9 were selected and further tested and optimized with waste loading ranging from $2.6 \mathrm{wt} \%$ to $16.22 \mathrm{wt} \%$ on a dry basis. The formulation TB6 was also employed as the starting point for the formulation of the DuraLith waste form for Hanford secondary waste used in a more recent study in which the DuraLith waste form was spiked with ${ }^{99} \mathrm{Tc}$ [3]. Based on the promising results from this most recent study [3], that formulation (TB6) provided a natural starting point for further development and optimization in the present work. 


\section{SECTION 2 WASTE SIMULANT COMPOSITION AND PREPARATION}

PNNL provided the compositions of four liquid waste simulants (S1, S2, S3, and S4). The compositions are shown in Table 2.1. Radionuclides were not used in the present work. Therefore, for the preparation of the simulants, technetium $\left({ }^{99} \mathrm{Tc}\right)$ was replaced by rhenium and radioactive iodine $\left({ }^{129} \mathrm{I}\right)$ by stable iodide. Mercury was deleted because of its toxicity. Simulant (S1) is representative of the baseline ILAW off-gas caustic scrubber effluent downstream of the ILAW HEPA filters. Two other simulants (S2 and S3) are variants of this same stream, as projected by WTP flow-sheet models over the course of WTP operations. The fourth simulant is representative of an alternative flow sheet in which the ILAW submerged bed scrubber condensate is blended, on occasion, with the caustic scrubber stream baseline flow sheet. Note that the compositions in Table 2.1 are provided at $1 \mathrm{M} \mathrm{Na}$ concentration but the baseline sodium concentration requested by PNNL is $2 \mathrm{M} \mathrm{Na}$. We have used this information to prepare 15-liter batches of each simulant. The chemicals, the molar concentrations, the target masses, the order of addition, and other data are shown for S1 in Table 2.2.

In order to increase the waste loading in DuraLith products we have prepared simulants with higher concentrations than given in Table 2.2. Using less water for the same amount of solid material increased the concentration of waste stream S1, as shown in Table 2.2. Table 2.3 shows the recipe to make a batch of S1 simulant with a concentration four times the base concentration $(8 \mathrm{M} \mathrm{Na})$. Table 2.4 shows the respective recipe for a batch of S1 simulant with a concentration six times the base line concentration $(12 \mathrm{M} \mathrm{Na}$ ). Fractions of the $\mathrm{S} 1$ solution with $8 \mathrm{M} \mathrm{Na}$ were diluted with water to make simulants with 4,5 , and $6 \mathrm{M} \mathrm{Na}$.

Table 2.5 shows the recipe to make a 15-liter batch of S2 waste simulant with $2 \mathrm{M} \mathrm{Na}$. Table 2.6 shows the corresponding recipe for the S3 waste simulant. Solutions with higher than 2 $\mathrm{M} \mathrm{Na}$ were not prepared. Table 2.7 shows the recipe for waste simulant S4. This waste solution was also prepared at three times higher concentration $(6 \mathrm{M} \mathrm{Na})$, as shown in Table 2.8.

The batches of simulated waste were stored at room temperature. None of the liquids were entirely clear after preparation. Over time, small deposits were found on the bottom of the containers. These deposits were re-suspended prior to using aliquots of the waste for sample preparation. 


\section{SECTION 3 SOLID COMPONENTS}

\subsection{Materials for the Composite Binder}

The selection of materials for the composite binder was made based on the first tests with the TB6 (NT6PNL) formulation from previous work [3]. That worked showed that it would be prudent to pursue two rather than only one type of binder. The main reason for this decision was that early formulations based on TB6 showed surface cracks and the cause of these cracks was not immediately clear. Both of the binders selected for the present work, shown in Table 3.1, are based on previous work [3]. In this work we refer to them as "metakaolin-based" (MK) and "blast furnace slag-based" (FS) binders. Metakaolin-based binders and the respective DuraLith formulations contain more metakaolin than blast furnace slag. Blast furnace slag-based formulations contain less metakaolin than furnace slag. Table 3.2 lists the binder materials used in this study. Enhancer materials will be discussed in Section 3.2. Table 3.3 provides the results from analyses of the binder materials measured by X-ray fluorescence spectroscopy (XRF).

Metakaolin $\left[\mathrm{Al}_{2} \mathrm{Si}_{2} \mathrm{O}_{7}\right]$ is dehydrated kaolinite $\mathrm{Al}_{2} \mathrm{Si}_{2} \mathrm{O}_{5}(\mathrm{OH})_{4}$. Metakaolin is made by heating kaolinite until it becomes X-ray amorphous. Metakaolin is very reactive and forms gel particularly fast in highly alkaline solutions. If an appropriate water-to-metakaolin ratio is applied, the mixture solidifies into a geopolymer without further additives. However, metakaolin is relatively expensive and can at least partially be replaced by other amorphous aluminosilicate materials, such as fly ash Class F, ground granulated blast furnace slag (FS), and/or fly ash Class C.

Blast furnace slag contains a few percent of sulfide and can help establish a low redox potential together with other DuraLith enhancers. Therefore, blast furnace slag may support reduction of technetium $\left(\mathrm{Tc}^{7+}\right.$ to $\mathrm{Tc}^{4+}$ ), which should decrease its mobility. By using a composite binder in the DuraLith formulations, e.g., metakaolin and BFS, both alkali aluminosilicate (AAS) and calcium silicate hydrate $(\mathrm{CSH})$ gels will be generated, providing a durable matrix to encapsulate and immobilize waste constituents. Although blast furnace slag does react with water to form $\mathrm{CSH}$-phases (known as tobermorite gels), alkali activation significantly enhances the rate of formation of tobermorite gel $[5,6,7,8,9]$. In its crystalline form, tobermorite is a phyllosilicate. Inorganic salts in the waste streams do not significantly affect the tobermorite gel formation or the setting rate of the waste form.

Fly ash Class $\mathrm{F}$ was found to be a good candidate for a composite binder. Alkali activation of fly ash Class $F$ results in a zeolitic, alkali aluminosilicate (AAS) gel, which tolerates incorporation of waste with up to $1 \mathrm{~mol} / \mathrm{L}$ chloride, or $3 \mathrm{moles} / \mathrm{L}$ nitrate, or $3 \mathrm{moles} / \mathrm{L}$ boric acid. Combinations of these species have not yet been tested. The wide range of particle sizes in fly ash Class F may lead to less porosity of the final product. Fly ash Class F acts like metakaolin during geopolymerization but is less reactive; therefore, the time to hardening or setting of a paste can be manipulated by adding fly ash to the composite binder. Fly ash Class F is also significantly less expensive than metakaolin. In this study, some tests were performed where up to $\sim 5 \mathrm{wt} \%$ fly ash replaced the same amount of metakaolin or blast furnace slag in the DuraLith recipes. 
Silica fume is a byproduct of the production of silicon and is available in large quantities. Silica fume is amorphous silica and is soluble in alkali hydroxide. The material used in this study came from Norchem Inc. and contains $2.42 \mathrm{wt} \%$ carbon and a small amount of elemental silicon. Based on information provided by Norchem, it was assumed that hydrogen generation due to residual elemental silicon upon dissolution in alkali would not be an issue; however, as discussed subsequently, small but measurable amounts of hydrogen were detected in the present work. Funded by Norchem, Zhang, et al. (2000) tested twenty-four silica fume (SF) products from six different furnaces (silicon and Ferrosilicon), over a four-month period. The test program was conducted by measuring: (1) the gas generated from interaction of SF (both densified and undensified), with $\mathrm{NaOH}$ solutions, (2) the gas generated after controlled additions of elemental silicon [1 to 5\%] and (3) measuring gas generated in cement mortars. The test equipment and procedures were based on the German specification European EN 13263-1. It was assumed that $100 \%$ of the gas generated was hydrogen and the measured amount yielded the silica fume's elemental silicon. The 24 silica fume samples generated an average elemental silicon content of $0.41 \%$ when interacted with $\mathrm{NaOH}$ solution. Gas composition tests showed that $92.4 \%$ of the gas was hydrogen on average, the balance being nitrogen and oxygen, lowering the average elemental silicon content to $0.37 \%$. Tests with cement mortars showed that the hydrogen gas released was less than $3.1 \%$ of the maximum amount generated in the $\mathrm{NaOH}$ solution. Using the mortar data, would suggest that the effective elemental silicon content was $0.03 \%$, which would make hydrogen gas generation very small. In 1999, the test results were presented to the ASTM C 1240, Task Group 4 Silica Fume Specification Committee, which decided that there was no need to have a silicon content maximum in the ASTM C1240 specification (10a Standard Specification for Silica Fume Used in Cementitious Mixtures, Cement mortars-specifications).

Copper smelter slag is an alternative material for blast furnace slag and was used in some recipes in amounts of up to $5 \mathrm{wt} \%$, replacing the same amount of blast furnace slag. Copper smelter slag is relatively reactive in highly alkaline solution. Usually the copper slag contains several percent of elemental copper and some sulfide. It is possible that copper precipitates iodide present in the pore solution thus improving long-term fixation of ${ }^{129} \mathrm{I}$ in DuraLith.

In addition to the above mentioned materials, fine river sand was added to the binder. The sand helps to increase the mechanical durability, lowers the cost of binder materials, and allows manipulation of the workability of the paste. Fine river sand $(20 \mathrm{wt} \%)$ was also used in the previously studied DuraLith formulation NT6PNL (Table 3.1).

\subsection{Enhancers}

In order to enhance the fixation of rhenium (technetium) and iodine (iodide) in a DuraLith waste form, several solid compounds were added to the mixture of binder materials and to the simulated waste immediately before it was used to make an activator solution. The function of these enhancers is element-specific. It is assumed that rhenium (technetium) will occur in the liquid waste in its most soluble form, i.e., as perrhenate, $\mathrm{ReO}_{4}{ }^{-}$(pertechnetate, $\mathrm{TcO}_{4}{ }^{-}$). In this case, chemicals such as $\mathrm{SnF}_{2}$ or $\mathrm{Na}_{2} \mathrm{~S}$ are used to reduce $\mathrm{Re}^{7+}$ to $\mathrm{Re}^{4+}$, which forms an insoluble oxide $\left(\mathrm{ReO}_{2}\right)$ that is then dispersed within the DuraLith paste and fixated in the final waste form. Iodine is expected to occur dissolved as iodide in the waste solution. In this form, iodine can be fixated by forming an insoluble compound. A commercial product 
Ag-zeolite (IONEX Ag 900 from Molecular Products) has been used in previous work [3] and here. IONEX Ag 900 from Molecular Products is loaded with $\mathrm{Ag}^{+}$, which can react with iodide to form AgI. 


\section{SECTION 4 FORMULATION OPTIMIZATION}

As mentioned in Section 3.1, two basic composite binders were pursued in the present work, the metakaolin-based and the blast furnace slag-based binder. Both binder/activator mixtures were subjected to a formulation optimization process. The results of previous work were taken into consideration, bearing in mind that the waste compositions have changed and new materials such as copper slag have been introduced, which require additional testing. In this section we describe the steps toward optimization. In this section we describe the compositional constraints, compositional changes within those constraints (with emphasis on water), experimental procedures, and the test results. Based on the results, we make a recommendation in Section 5 of a formulation for testing at a larger scale.

\subsection{Compositional Constraints}

Based on previous experience, durable DuraLith waste forms for a given waste stream can be made when a set of constraining parameters are met. A well-known example is the waterto-solids ratio. Here, water means the mass of pure water either used as such and/or contained in a solution, in a chemical as water of crystallization, and in a hydroxide (e.g., $2 \mathrm{KOH}=\mathrm{K}_{2} \mathrm{O}+$ $\mathrm{H}_{2} \mathrm{O}$ ). The applicable parameters are listed in Table 4.1. The first column of Table 4.1 shows that the constraining parameters apply to the binder and activator (here metakaolin-based [MK] or blast furnace slag-based [FS]). The second column (rows 2 and 3) of Table 4.1 shows the two types of binders for which characteristic mass ratios are given in column 3 . Then, column 2 shows that there are three mass ratios for the activator solution for a MK-based DuraLith, which must be kept within the limits given in column 3. The $\mathrm{SiO}_{2} / \mathrm{Al}_{2} \mathrm{O}_{3}$ ratio means that the number of moles of silica already in the waste and/or added to the waste solution divided by the number of moles of $\mathrm{Al}_{2} \mathrm{O}_{3}$ contained in solids of a metakaolin-based binder must fall in the respective range shown in column 3. The same applies to the number of moles of alkali hydroxide already contained in and/or added to the waste. Finally, the number of moles of $\mathrm{H}_{2} \mathrm{O}$ in the waste divided by the number of moles of alkali oxide $\left(\mathrm{Me}_{2} \mathrm{O}\right)$ initially contained in and/or added to the waste must fall in the range given in column 3. Column 2 in Table 4.1 shows $\mathrm{H}_{2} \mathrm{O}, \mathrm{SiO}_{2}$, and $\mathrm{Me}_{2} \mathrm{O}$, respectively, related to the sum of the three binder constituents, blast furnace slag, fly ash, and copper slag. The respective mass ratios are given in column 3 . Note that alkali in the waste not present in the form of hydroxide is not considered in the ratios given in Table 4.1. For example, if a fraction of $\mathrm{Na}$ were present as $\mathrm{NaNO}_{3}$, that fraction would not be counted. The last row in Table 4.1 shows how much river sand can be contained in these DuraLith formulations. River sand consists essentially of $\mathrm{SiO}_{2}$. However, $\mathrm{SiO}_{2}$ in the form of sand is treated as an inert material that does not contribute significantly to the reactive part of silica contained in a DuraLith paste. The numbers for river sand are given in weight percent. The last column in Table 4.1 shows the optimum ranges of the ratios given column 3 . These ranges are the result of this work. 


\subsection{Optimizing Products within the Ranges of Compositional Constraints}

After having established the compositional constraints under which a DuraLith waste form can be optimized, we focused our attention primarily on the total amount of water to be used, i.e., on the ratio of water-to-solids. We refer to this ratio as W/C. Note that 'solids' in this ratio includes all solid additives, except sand, the solids (dissolved or not dissolved) in the pristine waste simulant, and enhancers added to it.

The general guideline is that the lower the water-to-solids ratio, the higher the mechanical durability of geopolymer. Literature data (Section 4.4.6) indicate that the compressive strength increases with decreasing pore size. Smaller pores lower the diffusivity of critical elements to be retained in the waste form. The curing time of 28 days for geopolymers in general and for DuraLith products in particular, made it necessary to try out several compositions in parallel rather than progressing from one composition to the next.

The water content is critical also because it affects the time for which a geopolymer paste can be poured or pumped prior to setting. Given the fact that the constraining parameter ranges, including the water-to-solids ratio, were already known, optimization could be conducted within relatively narrow compositional fields. Yet, effects such as consistency of the paste, bleeding, time to harden, surface cracking, swelling, shrinkage, salt deposits, compressive strength and others remained unknown.

Optimizing DuraLith waste forms for the HSW stream requires varying the chemical composition until pastes are found that provide satisfactory workability, do not show or separate free water, harden without bleeding and cracking, do not show significant swelling or shrinkage, are mechanically durable, and satisfy chemical durability requirements.

\subsection{Experimental Procedure}

In this section we describe the experimental methods used to prepare and characterize all DuraLith products made with the waste simulant compositions given in Tables 2.2 to 2.8 ; the results are reported in Section 4.4.

\subsubsection{Sample Preparation}

A recipe was developed for each sample composition. The recipe prescribes the constituents, their chemical form, their masses and the order of addition. An example of those recipes is provided in this report for the DuraLith product recommended for testing on a larger scale (Section 5). The mixture of the solids for the composite binder and the preparation of the activator are done separately. Typically, for lab-scale testing, recipes were for about $4 \mathrm{~kg}$ of DuraLith paste.

Activator: To prepare the activator, the simulated waste solution was transferred from a storage container into a 2-liter glass beaker. Then, 15 to $20 \mathrm{~g}$ enhancer for Re (Tc), i.e., $\mathrm{SnF}_{2}$ or $\mathrm{Na}_{2} \mathrm{~S}$, was added under stirring. (A mechanical stirrer was used since magnetic stirrers are not powerful enough.) If not specified in the tables in Section 4.4, the enhancer for $\mathrm{Re}$ is $\mathrm{SnF}_{2}$. (We 
found that fluoride is more compatible with geopolymer materials than chloride). After two hours of stirring, solid $\mathrm{NaOH}$ and $\mathrm{KOH}$ were added slowly under stirring, followed by adding silica fume in small portions. Dissolution of alkali hydroxide is a strongly exothermic process. Therefore, solid $\mathrm{NaOH}$ and $\mathrm{KOH}$ must be added carefully to avoid overheating of the solution. If too much silica fume is added at one time, the mixture may become very stiff and difficult to stir effectively with a magnetic stirrer. Dissolution of silica fume is a slow exothermic process. Heat is released more slowly than with alkali hydroxide. Further discussion on heat generation and temperature is provided in Section 4.4.10. Stirring was continued overnight until a homogeneous pourable liquid was obtained. After the addition of silica fume, bubbles were seen on the surface of the solution. Production of small bubbles may cease overnight or last several days, depending on the amount of silica fume added, the concentration of the waste in the activator solution and whether a strong mechanical stirrer is used. Stirring should be continued until bubbling ceases in order to avoid formation of bubbles during hardening of the DuraLith paste, which could lead to swelling of the solid. In this work carbon-free amorphous silica (Cabot Corporation) and potassium silicate glass powder (Kasolv16 from PQ Corporation) were tested as alternative additives and formation of bubbles was not observed.

Tests were conducted to determine whether hydrogen was generated as a result of residual silicon in the fumed silica. To detect hydrogen, about $1 \mathrm{~L}$ freshly prepared activator solution was placed in a closed 2-liter plastic bottle. Through an inlet and outlet in the lid, the gas phase (about 1.2 L) above the activator solution was pumped in a cycle. The gas in the loop was continuously sampled and analyzed for hydrogen. The experiment was run for 5 days. Hydrogen was detected in this test. Although the activator solution could not be stirred in this setup, it was manually shaken from time to time to release bubbles from the viscous solution. Without shaking, the bursting of individual bubbles caused hydrogen concentrations of about 50 ppmv $(\mathrm{v}=$ volume). If the activator was left alone over night and shaken the next morning, a maximum hydrogen concentration of about $2.5 \mathrm{vol} \%$ was detected. The hydrogen concentration in the system decreased after each burst because hydrogen was lost by diffusion. However, with this simple setup it was not possible to measure the total amount of hydrogen generated and to calculate the content of silicon.

Fumed silica can be replaced by potassium silicate glass powder or by silica fume free of carbon and silicon. The latter material is heat-treated silica fume and is commercially available for a slightly higher price than untreated silica fume.

Overnight stirring causes some loss of water. This loss is within the tolerance (robustness) of our DuraLith formulations. Extended stirring, i.e., 3 days and longer, may cause higher water losses, which may need to be compensated by adding water at the end. The amount must be determined experimentally based on weight loss. If water is added at the end, stirring must be continued until a homogeneous paste is obtained. For a given DuraLith formulation, information on mass loss is part of the recipe.

Ideally, an activator solution contains completely dissolved silica, which is in equilibrium with its silicate species. An activator solution, which contains undissolved silica and a high waste concentration (>6 M Na), i.e., less water, becomes thixotropic and is difficult to stir. This may require more intensive and longer stirring until a homogeneous solution is obtained. Such an activator solution should not be left unstirred and, when ready, should be used immediately to make the DuraLith paste. We found that heating a thixotropic activator accelerates the process of homogenization. 
When preparing an activator solution with the simulated waste S4 (Table 2.1), addition of alkali hydroxide leads to release of ammonia and a well-vented area is needed. This was much less evident when using S1, S2, and S3.

Composite binder: To prepare the composite binder, the solid constituents were weighed and stored in separate containers. Figure 4.1 shows the binder ingredients and the amended waste simulant (activator) in the middle ( $\mathrm{SF}=$ silica fume, BFS = blast furnace slag, Ag-Z = silver zeolite, $\mathrm{MK}=$ metakaolin). The activator is black because the silica fume contains carbon. The binder constituents were then transferred into a 5-gallon bucket in the prescribed order and mixed with a hand-held mixer (EHR 23). This is shown in Figure 4.2. The enhancer for iodide fixation (Ag-zeolite) was added to the binder materials. The 5-gallon bucket was fixed in a device that held it in place during stirring.

The DuraLith paste: After thorough mixing the activator was poured into the solids under mixing (Figure 4.3). Mixing was continued until a pourable paste formed, free of lumps and solid material. This took no longer than 10 minutes. Figure 4.4 shows an early stage of mixing. Figure 4.5 shows that the paste is very dry in the beginning. The lumps of dry material begin to disappear after a few minutes (Figure 4.6) and a homogeneous paste is obtained (Figure 4.7). Toward the end of mixing, a prescribed relatively small amount of silica fume was added to the paste. Experience has shown that this improves the workability of the paste. Figure 4.8 shows the paste ready to pour. Figure 4.9 shows the paste filled into 2" by 4 " plastic containers sitting on a vibrating table to remove air bubbles introduced during stirring. Usually eight to nine containers are filled with one batch. During the first 24 hours a lid was put on the containers. The lid has a small hole (about $6 \mathrm{~mm}$ in diameter) for water to escape as it is expelled from the hardening paste during poly-condensation. Figure 4.10 shows two of nine samples still capped. Figure 4.11 shows samples after demoulding.

Waste loading: This is the mass in weight percent of waste solids contained in a dry DuraLith product. Waste loading increases with increasing concentration of waste constituents dissolved and suspended in the pristine simulant. However, an increase of the baseline waste concentration, referred to in this report as ' $2 \mathrm{M} \mathrm{Na}$ ', by a factor of two (4 M Na), does not increase the waste loading by exactly a factor of two, because the amount of water needed to make an acceptable DuraLith product depends on the constraining parameters in Table 4.1. Examples of the change of waste loading with waste concentration can be seen in Table 4.10, columns 14 and 15 . For example, sample S1-4X3 contains $4.58 \mathrm{wt} \%$, whereas sample S1-8X1 contains $10.7 \mathrm{wt} \%$ waste solids, slightly more than double $(\mathrm{X}=\mathrm{M} \mathrm{Na})$.

\subsubsection{Free Liquid on the Paste}

After mixing (Section 4.3.1) the paste rested for a few minutes in its container, prior to transfer into moulds. During this time, the paste surface was inspected for free water. None of the formulation tested in the present work showed any water separating from the paste. Had such a phenomenon been observed, the recipe would have been considered not suitable because the ratio of water-to-solids would have been much too high. 


\subsubsection{Workability}

The workability of DuraLith pastes is an important property for the waste form production process in the laboratory and for large-scale production. Geopolymer pastes must be workable after thorough mixing of the raw materials, i.e., it must be possible to manipulate the paste mechanically in any desirable way for a certain period of time. Thereafter, the material begins to harden. Many methods have been proposed to evaluate workability of cement and concrete pastes [11]. The slump test is a simple test that is applied to evaluate workability of Portland cement or concrete paste on site. However, it requires a large volume of paste (about 2 gals). In contrast, direct measurements of the rheological properties of the sample using a rheometer can be performed on a smaller sample volume to determine the dynamic component of workability in a more quantitative fashion. As an example, the Bingham model for fluid flow has been used successfully to represent the rheological behavior of freshly prepared concrete mixes. This is a relatively simple model that relates shear stress and shear rate in terms of the yield stress and the plastic viscosity, which better represents workability. Accordingly, rheograms (shear stress vs. shear rate) can be measured for the geopolymer pastes at a fixed time after mixing using concentric cylinder or vane rheometers and the data can be analyzed using simple rheological models. However, based on experience and for laboratory testing, workability can be evaluated qualitatively from the paste consistency during pouring and the time for which this consistency is maintained. Thus, we provide qualitative information by reporting the time it takes for a given paste to begin to harden. 'Begin to harden' refers to the time (elapsed after the beginning of mixing) at which the paste cannot be removed form the mixing vessel without difficulty.

\subsubsection{Curing}

Using a spatula, the pastes described in Section 4.3.1 were transferred into plastic cylindrical moulds for setting and 28-day curing. The moulds have an inner diameter of 2 inches and an inner height of 4 inches. During filling, the moulds sat on a vibrating table, which was used to promote release of air bubbles from the paste. After filling nine containers in this way, the surface of each sample was sealed with a lid with a hole for water to escape. Water must be able to evaporate from the hardening geopolymer paste. The amount of water remaining in the structure depends on the composition of the geopolymer. In the presence of blast furnace slag, water is involved in the formation of calcium silicate hydrate gel and remains in the structure. In metakaolin-dominated geopolymers, most of the water will leave the solidifying product. Based on previous measurements [2], the largest fraction of water (up to $82 \%$ ) is released during the first 28 days of curing. The remaining water supports further curing over long periods of time, which is reflected, e.g., in increasing compressive strength after 28 days.

\subsubsection{Bleed Water}

Usually the lids of the moulds were opened after 24 hours and the sample surfaces inspected for bleed water and salt deposits. Bleed water on DuraLith samples manifests itself either by a wet sample surface or by the presence of one or more drops of liquid. However, the moisture or liquid evaporates quickly leaving practically no residue behind. Frequently, the presence of drops of liquid is due to the fact that the hole in the lid of the mould was too small 
for water to evaporate fast enough. The size of the hole should be about $6 \mathrm{~mm}$ in diameter. Small salt deposits were seen frequently on samples with higher waste loading upon demoulding after 24 hours. If such deposits were seen, the remaining not yet opened samples from one preparation (usually eight) were not opened. They were allowed to cure in their moulds for up to two weeks. After two weeks, the samples were demoulded and salt deposits were not observed. Hence, when we report in Section 4.4 that there was no salt deposit, this means that there were certainly no deposits after two weeks.

At the beginning of this work, some samples were not covered during curing and did not show any bleeding, even though high (not optimized) W/C ratios were used (see Section 4.4.1, Tables 4.2 and 4.4, samples S1-2X2 to S1-2X9). Later in the project it turned out that samples with an optimized $\mathrm{W} / \mathrm{C}$ ratio and with a lid on did not bleed at all and variation of the hole size was not critical.

\subsubsection{Surface Deposits, Cracks, Shrinkage, and Swelling}

All samples were inspected for surface deposits, cracks, shrinkage, and swelling. These phenomena were evaluated qualitatively with respect to their significance for the process of product optimization:

Surface deposits: Deposits may occur as a result of a high salt content in a DuraLith formulation. This could be the case when the waste loading is too high and when the $\mathrm{W} / \mathrm{C}$ ratio is too high. If the deposits were small, i.e., if only spots occurred, that deposit would not disqualify a given formulation. If thicker layers occurred or complete coverage of the surface took place, the formulation would not be considered for further optimization.

Surface deposits could be suppressed by late demoulding (up to 28 days) or by sealing demoulded samples into plastic bags. This suggests that the rate at which water escapes from the sample can be important.

Cracks: Cracks may be found on the surface of a sample and their depth may either be limited to a thin surface layer or they may have penetrated deep into the sample. Though the exact cause of cracks is not known, we believe that their appearance is related to an improper ratio of water-tosolids. Lowering the water-to-solids ratio reduces the risk of surface cracking. Because cracks of any kind are undesirable, such DuraLith formulations were eliminated from further consideration in the product optimization process.

Shrinkage: This phenomenon was evaluated by looking at the top surface of a sample, which should be flat. In very rare cases, samples were found with mildly curved inward (concave) upper surfaces. This observation was not considered critical and was neglected.

Swelling: Some DuraLith formulations may show convex upper surfaces. This phenomenon is not considered critical, if swelling is as little as observed. More swelling could lead to cracking, which should be avoided. However, unevenness may affect compressive strength measurements. Therefore, all samples were capped with rubber pads to compensate for minor unevenness. The 
extent to which shrinkage and swelling were observed did not have any noticeable effect on measured product properties such as compressive strength and TCLP.

\subsubsection{Mass Loss}

Mass loss measurements were conducted on selected samples to determine the loss of water as a function of curing time. The samples were weighed repeatedly. Such measurements were conducted and reported previously [2] where we found that the DuraLith samples lost between 40 and $82 \%$ of the initial water during a curing period of 28 days at room temperature.

\subsubsection{Free Liquid in Cured Samples}

To determine the amount of free liquid in a DuraLith waste form sample, the Paint Filter Liquids Test (EPA SW-846 Method 9095B, Nov. 2004) was performed. We used the experimental setup shown in a Figure in Method 9095B. The setup is very simple: A glass funnel and filter paper, large enough to hold $100 \mathrm{~g}$ of DuraLith, rest on the mouth of a glass measuring cylinder. About $100 \mathrm{~g}$ of crushed DuraLith material was placed into a mesh-60 paint filter. Liquid would be collected in the glass cylinder beneath the filter. The test was conducted in duplicate at room temperature and terminated after 5 minutes.

\subsubsection{Compressive Strength}

Compressive strength was measured for one sample of each DuraLith formulation. A Humbold Test Mark CM-4000-SD instrument was used and the ASTM C 39/C 39M method was followed. A 2" x 4" cylinder was measured after it was cured for 28 days. The samples were capped with rubber pads because the top and the bottom surfaces were not sufficiently planeparallel to be measured bare.

\subsubsection{Porosity}

The mixing process described in Section 4.3.1 introduces air bubbles into the geopolymer paste. The viscosity of the paste was too high for all bubbles to rise before the paste hardened. To support release of bubbles, the sample containers were vibrated during filling (Section 5.3.4). Additionally, moving a metal rod by hand up and down in the paste increased the release of bubbles. However, some bubbles still remained inside, which was evident when the samples were cracked and fracture surfaces visually inspected.

\subsubsection{Toxicity Characteristic Leaching Procedure (TCLP)}

The Toxicity Characteristic Leaching Procedure (TCLP) was used to measure the release of the hazardous elements $\mathrm{Cr}, \mathrm{Ag}, \mathrm{As}, \mathrm{Cd}, \mathrm{Pb}$, as well as $\mathrm{Cu}, \mathrm{Sn}$, $\mathrm{Re}$ and I. The elements $\mathrm{Ag}, \mathrm{Cu}$, and $\mathrm{Sn}$ were measured because $\mathrm{Ag}$ and $\mathrm{Sn}$ were added to the formulation as Ag-zeolite and $\mathrm{SnF}_{2}$, respectively, and $\mathrm{Cu}$ is contained in copper slag. Rhenium was added to the waste as $\mathrm{NaReO}_{4}$ to 
simulate the radionuclide ${ }^{99} \mathrm{Tc}$ in its soluble form ${ }^{99} \mathrm{TcO}_{4}{ }^{-}$, and stable iodine as NaI to simulate the radionuclide ${ }^{129} \mathrm{I}$. The hazardous elements and rhenium were analyzed by direct current plasma atomic emission spectrometry (DCP-AES) and iodide by an ion-selective electrode (9653BNWP, Thermo Scientific).

\subsubsection{ANSI/ANS-16.1 Leaching Test}

The ANSI/ANS-16.1 (Measurement of the Leachability of Solidified Low-Level Radioactive Wastes by a Short-Term Test Procedure) was used to measure the diffusivities of $\mathrm{Re}, \mathrm{I}$, and Na. Because of the relatively long duration of the test (90 days) the results of this test were not used as a tool to improve the chemical durability of our DuraLith formulations. Only a few samples were selected for testing. $\mathrm{Na}, \mathrm{K}, \mathrm{Re}$ and other elements were measured by DCPAES and iodide was measured with an ion-selective electrode (9653BNWP, Thermo Scientific).

\subsubsection{Heat Generation (Activator and Paste)}

Preparation of DuraLith waste forms is associated with generation of heat because the most important chemical reactions are exothermic. This is evident because solid $\mathrm{KOH}$ and $\mathrm{NaOH}$ must be dissolved in the simulated waste solution, i.e., essentially in water, to prepare the activator. Heat generation in the liquid waste can be lessened, if one uses soluble sodium or potassium silicate glass powder instead of $\mathrm{KOH}, \mathrm{NaOH}$ and silica fume. The temperature increase associated with the heat generated depends on various factors, including the mass of activator solution produced per batch, the mass of alkali hydroxide and silica fume to be dissolved, the rate at which these chemicals are added, the thermal conductivity, and the size and geometry of the container.

To what extent heat is generated when the activator and the composite binder are mixed and react depends on the composition of both components. The associated temperature increase depends on the size of the batch, the thermal conductivity of the paste, and adjacent materials, such as the container.

Temperature profiles resulting from heat release have been measured for the activator solution during preparation and for two DuraLith pastes immediately after preparation. The experimental setup is presented in Section 4.4.8 together with the results.

\subsection{Results}

In this section we report waste form compositions and properties that were obtained with the baseline (2 $\mathrm{M} \mathrm{Na}$ ) simulant compositions $\mathrm{S} 1$ to $\mathrm{S} 4$. This includes the results on the robustness of DuraLith formulations vis-à-vis process upsets (composition variation tests). The variation of waste loading requires slightly different DuraLith compositions and is therefore reported in a separate section (Section 4.4.5). 


\subsubsection{DuraLith for Waste Simulant S1 (Water Optimization)}

Table 4.2 shows the results of experiments conducted with waste simulant S1. The objective of the tests was to optimize the water content. As an example, optimization involves finding the best product when the use of less water on the one hand reduces the risk of surface cracks and bleeding but, on the other hand, produces a stiffer, less workable, earlier-setting paste. A total of 19 formulations were tested, which led to the production of 161 samples. The data in Table 4.2 are ordered chronologically. This table and the following composition tables (Tables 4.3, 4.6, and 4.8) show the DuraLith formulation names first, which contain the type of waste ( $\mathrm{S} 1)$, the waste concentration $(2 \mathrm{X}=2 \mathrm{M} \mathrm{Na}$, baseline) and a number. ' $\mathrm{R}$ ' stands for 'repeat' and indicates that this formulation was made again because some error had occurred during fabrication and the batch had to be repeated. Column 2 of Table 4.2 shows the type of formulation (metakaolin-based [MK] or blast furnace slag-based [FS]). Columns 4 and 5 show the MK and FS concentrations in weight percent, column 6 the percentage of $\mathrm{SiO}_{2}$ filler added during mixing the binder and activator, columns 7 to 9 (activator) the percentages of alkali hydroxide (expressed as oxides) and $\mathrm{SiO}_{2}$ added to waste simulant $\mathrm{S} 1$, column 10 the percentage of sand, column 11 (enhancer for iodide) shows the percentage of Ag-zeolite, and columns 12 and 13 (HSW) the percentage of solids and water provided by the waste simulant. The numbers in columns 4 to 13 add up to 100 percent (column 14), where 100 percent is the freshly prepared paste. The percentages in columns 4 to 13 increase as the paste hardens and cures because more and more water evaporates (Section 4.4.9). Column 15 shows the water-to-solids ratio in a freshly prepared paste. Column 16 shows which enhancers were used. The mass of enhancer(s) for $\mathrm{Re}$ was not included in the calculation of a formulation; enhancers were added separately. The mass corresponds to $5 \mathrm{~g} / \mathrm{kg}(0.5 \%)$ of a calculated water-free DuraLith product.

Based on previous work [3] (product NT6PNL, Table 3.1), only metakaolin-based (MK) materials were prepared at the beginning (first five formulations in Table 4.2). Product properties are shown in Table 4.4. This and the following tables (Tables 4.5, 4.7, and 4.9) show the W/C ratios in column 4 , the qualitative evaluation of the paste in column 5 , the curing condition during the first 24 hours in column 6 , bleeding information in column 7, the time until the paste hardened in column 8 , information on cracking in column 9 , and the compressive strength of the final DuraLith product after 28 days of curing in column 10.

Table 4.4 shows that a slight improvement was made towards a less fluid paste when the $\mathrm{W} / \mathrm{C}$ ratio was lowered form 0.365 to 0.319 . There was no bleeding. However, independent of the $\mathrm{W} / \mathrm{C}$ ratio, all samples of all formulations showed cracks on their entire surfaces (side, bottom, and top) when they were left in open air after demoulding. Nevertheless, the compressive strength was surprisingly high (roughly 12,000 to $13,000 \mathrm{psi}$ ), far exceeding the required minimum strength of $500 \mathrm{psi}(3.54 \mathrm{MPa})$. This is probably due to the fact that the cracks healed during the 28-day curing period, leaving the crack pattern visible. However, surface cracks, healed or not, may have a deleterious effect on chemical durability because of a potential increase in surface area. Also, it is not known whether the cracks would grow and reopen in the long-term. Therefore, samples with surface cracks were excluded from further consideration.

Self-healing is a known phenomenon in Portland-cement-based concrete. Usually the micro-cracks are less than $1 \mathrm{~mm}$ in depth (surface cracks). In self-healing concrete, sodium silicate particles encapsulated in organic or inorganic compounds release sodium silicate when they break apart upon drying. The sodium silicate reacts with calcium hydroxide to form calcium 
silicate hydrate, which glues the micro-cracks in the presence of moisture. In DuraLith, microcracks form in the early drying stage. Later, the moisture flow may carry small amounts of dissolved alkaline aluminosilicate species toward the sample surface. Gel could form upon drying and seal the cracks.

Since it was not known whether further reduction of the W/C ratio would yield a crackfree material and whether other complications would occur, the decision was made at this point to work with two formulations rather than one, i.e. with metakaolin-based and furnace slag-based DuraLith formulations, as mentioned in Section 3.1. The remaining 14 formulations shown in Table 4.2 were prepared in pairs of MK- and FS-based products.

Looking at the $\mathrm{W} / \mathrm{C}$ ratio in Table 4.2 and neglecting the fact that slight changes of other constituents were made, we find that a W/C ratio for MK-based DuraLith of very close to 0.300 and very close to 0.280 for FS-based DuraLith yields a desirable consistency of the pastes (termed "easily pourable" or "pours slowly" in Table 4.4). No bleeding was observed. The workability, i.e., the "time to hardening" in Table 4.4, was satisfactory, and surface cracking was no longer observed. The compressive strength of the MK-based formulations remained practically unchanged (12,000 to $13,000 \mathrm{psi})$. Compressive strength seems to be independent of W/C and other minor compositional changes. FS-based DuraLith formulations exhibit significantly higher compressive strengths (roughly 16,000 to $24,000 \mathrm{psi}$ ). Though high strength was not a target of our work, this property was always used as a criterion for product optimization. In view of these observations, we elected to eliminate product formulations not exceeding 10,000 psi from further consideration.

In summary, formulations S1-2X10R to S1-2X21, except S1-2X16 (Tables 4.2 and 4.4), are candidates for further investigation. The $\mathrm{W} / \mathrm{C}$ ratio is considered optimized. In view of the schedule for this work, we selected a limited number of products for further investigation.

\subsubsection{DuraLith for Waste Simulants S2 to S4}

Table 4.3 shows nine formulations prepared with the waste simulants S2 to S4 (2 M Na). There are four formulations for S2, two for S3, and three for S4. The data are organized chronologically. All formulations were designed in pairs, i.e., one MK-based and one FS-based DuraLith. In the case of S4, two MK formulations were prepared. The changes in the chemical composition of the S2, S3, and S4 waste streams relative to S1 were considered small. A significant change of $\mathrm{W} / \mathrm{C}$ was considered unnecessary.

Table 4.5 shows the results for DuraLith samples for S2, S3, and S4. Some bleeding had occurred in 2 out of 9 formulations during the first 24 hours. The 'time to harden' was sufficiently long and the pastes were sufficiently fluid; thus, all pastes had good workability. No cracks were seen in any of the samples and the compressive strength was excellent. The optimum W/C ratio established for DuraLith products with the waste simulant S1 (2 M Na) yielded equally good products when each of the wastes S2, S3, and S4 were used instead of S1. 


\subsubsection{DuraLith with Combinations of Enhancers}

Products S1-2X12 and -13, Table 4.2, were used to test the effect of different enhancer combinations on the retention of iodide and rhenium. Table 4.6 shows the composition of two MK-based and two FS-based DuraLith products. The W/C ratio is exactly the same as in Table 4.2. The chemical compositions are practically identical. The enhancer combinations are either Ag-zeolite $/ \mathrm{Na}_{2} \mathrm{~S}$ or Ag-zeolite/ $\mathrm{SnF}_{2}$.

The properties of the pastes and the final products are shown in Table 4.7. The pastes showed properties similar to those listed in Table 4.2 for the respective products. The very slight condensation of water in one case during the first 24 hours of curing was not considered critical and the water evaporated quickly after demoulding. The 28-day old samples did not show any cracks and the compressive strength was excellent ( $>10,000$ psi) in all cases. Chemical durability results (TCLP) are shown later in context with all other samples (Section 4.4.7).

\subsubsection{DuraLith Variation Tests (Robustness)}

The FS-based DuraLith formulation S1-2X12 (Table 4.2) was selected to test the robustness of DuraLith formulations vis-à-vis process upsets. Table 4.8 shows the compositions of the pastes prepared. Two baseline formulations and eight variations were prepared. The letter ' $\mathrm{V}$ ' in the product name stands for 'variation'. The structure of Table 4.8 is the same as that of previous tables of this kind, except for the column 'Variation'. This column shows that DuraLith products were made with a deficit or surplus of 10 weight percent of MK or FS or silica fume (SF) in the binder or 10 weight percent $\mathrm{KOH}$ in the activator. The $\mathrm{W} / \mathrm{C}$ ratio in the variations was close to the optimum value of 0.278 (last column in Table 4.8). The enhancer for iodide (column 11 in Table 4.8) was Ag-zeolite. $\mathrm{SnF}_{2}$ was used to fixate rhenium (technetium).

Table 4.9 shows the properties of the pastes and final products. Column 2 shows the intentional deviation from baseline. The $\mathrm{W} / \mathrm{C}$ ratio is shown in column 4 . Note that none of the products showed bleeding; the time to hardening was longer than 90 minutes; there were no cracks in the products; and the mechanical durability was very good (roughly between 17,000 psi and $22,500 \mathrm{psi}$ ).

We conclude that process upsets of up to $\pm 10 \mathrm{wt} \%$ of an FS-based DuraLith product with optimized water content do not significantly affect the properties of the baseline products (pastes and solids). Though not tested, we would expect that the W/C-optimized MK-based formulation would exhibit similar properties vis-à-vis composition variations. This speculation is supported by the finding that variations of MK-based formulations, once optimized for $\mathrm{W} / \mathrm{C}$, have acceptable paste properties, have high compressive strength (not as high as FS-based formulations), and do not show cracking or bleeding (see Tables 4.2 to 4.7 ).

\subsubsection{DuraLith Formulations with Increased Waste Loading}

The study of DuraLith formulations with increased waste loading was conducted with the waste simulants S1 and S4 (Table 2.1). Both MK-based and FS-based formulations were studied. Unfortunately, the study could not make use of the optimized W/C ratios established in Section 
4.4.1, which was successfully applied in Sections 4.4.2 to 4.4.4. The significantly increased content of waste solids in the more concentrated waste and its lower water content made it necessary to increase the waste concentration stepwise, using $\mathrm{W} / \mathrm{C}$ ratios, which were close to the previously optimized values ( 0.280 for FS and 0.300 for MK).

Table 4.10 shows the compositions of 19 formulations with increased S1 waste loading, i.e., the waste loading was higher than that based on $2 \mathrm{X}(2 \mathrm{X}=2 \mathrm{M} \mathrm{Na}$, baseline $)$. Again, the data are ordered chronologically. The product names identify the waste loading as multiples of X. As mentioned before, $\mathrm{X}$ is a waste concentration in solution, not directly the waste loading in the solid product. The corresponding Na molarities of the waste solutions are shown in column 3 of Table 4.10. The highest tested 'waste loading' was about six times that of baseline, i.e., $6 \times 2 \mathrm{X}=12 \mathrm{X}=12 \mathrm{M} \mathrm{Na}$ ). The enhancer for iodide fixation was Ag-zeolite (column 12). The enhancer for rhenium (technetium) was $\mathrm{SnF}_{2}$. Column 12 of Table 4.10 lists the concentration of copper slag in the last 9 compositions. Copper slag was added at about $2 \mathrm{wt} \%$. The effect of copper slag on chemical durability was not studied in any detail. Potentially, the presence of copper in a DuraLith formulation could increases the retention of both iodide and rhenium. Copper could form insoluble $\mathrm{CuI}$ and, in addition to $\mathrm{SnF}_{2}$, reduce $\mathrm{Re}^{7+}$ to $\mathrm{Re}^{4+}$ thus supporting enhanced precipitation of insoluble $\mathrm{ReO}_{2} \cdot \mathrm{Fe}^{2+}$ in fayalite $\left(\mathrm{FeSO}_{4}\right)$, which is present in copper slag, may also support reduction of perrhenate.

Table 4.11 shows properties of pastes and solids based on compositions shown in Table 4.10. The most important finding is that the $\mathrm{W} / \mathrm{C}$ ratio can vary within a higher range when the waste concentration is higher than baseline. A range of about $0.350 \geq \mathrm{W} / \mathrm{C} \geq 0.300$ is possible for MK-based materials to obtain pourable pastes, no bleeding, and waste forms without cracks. The respective range for FS-based DuraLith products is roughly $0.320 \geq \mathrm{W} \geq 0.265$. However, for waste loadings using $6 \mathrm{X}$ and higher, a water reducer (DAVA 140M from Grace Constructions) was added in doses of $800-1200 \mathrm{ml}$ per $100 \mathrm{~kg}$ dry geopolymer solids. The water reducer, a polycarboxylate, helped to overcome the necessity of having more water to get a pourable paste and sufficiently long workability on the one hand and a non-bleeding crack-free product on the other. There are three products listed in Table $4.11 \mathrm{~b}$ that showed surface cracking. In these cases, problems occurred during the initial preparation but were eliminated when another batch was made. Salt deposits were observed on the sample surfaces. This deposit appeared in the form of a very thin grey film that could be removed with wet paper and did not occur again as the sample aged. The mechanical durability of all products was excellent and exceeded 10,000 psi in all cases.

Table 4.12 shows the composition of DuraLith formulations made with waste simulant S4. In this case, two higher waste loadings were tested with MK-based and FS-based materials using $4 \mathrm{X}$ and $6 \mathrm{X}$. Two percent of copper slag was added. Again, the enhancer for iodide fixation was Ag-zeolite and $\mathrm{SnF}_{2}$ for rhenium (technetium).

Table 4.13 shows properties of the pastes and the 7-day cured DuraLith products made with waste S4. The pastes were pourable. There was some water on the surfaces of the $4 \mathrm{X}$ samples upon demoulding, which evaporated quickly. No salt deposits or cracks were seen after 7 days. The time to hardening ranged between roughly 2 to 3 hours. The compressive strength was still low after 7 days, except for one product (S4-6X1) for which it exceeded 10,000 psi. 


\subsubsection{Porosity}

Figure 4.12 shows a photograph of DuraLith samples; the small circular holes are caused by bubbles in the paste. Figure 4.13 shows a scanning electron micrograph typical of a blast furnace slag-based DuraLith product. Figure 4.13 shows the hardened gel matrix phase, grains of furnace slag, and several spherical bubbles, which constitute closed porosity of the material. Bubble sizes range from $<10 \mu \mathrm{m}$ to about $100 \mu \mathrm{m}$. The open porosity (which refers to the fraction of the total volume in which fluid flow is effectively taking place (this excludes deadend pores or non-connected cavities) has not been quantified in any of our samples. However, literature data show, e.g., for a fly ash Class F-based geopolymer [12] that the average size of open pores decreases with the water/solids ratio $(\mathrm{W} / \mathrm{C})$ from about $500 \mathrm{~nm}(\mathrm{~W} / \mathrm{C}=0.30)$ to about $100 \mathrm{~nm}(\mathrm{~W} / \mathrm{C}=0.23)$. The average pore size was also shown to decrease with increasing $\mathrm{Na}_{2} \mathrm{O}$ content and compressive strength, e.g., about $1000 \mathrm{~nm}\left(5 \% \mathrm{Na}_{2} \mathrm{O}, 18 \mathrm{MPa}\right)$ and about $30 \mathrm{~nm}$ $\left(9 \% \mathrm{Na}_{2} \mathrm{O}, 60 \mathrm{MPa}\right)$.

This information cannot be transferred directly to discuss open porosity in our samples because our compositions are different, which affects the structure of the gel and its porosity. However, there seems to be a trend towards smaller pores with increasing compressive strength. In this regard our materials are likely to fall in the range of smaller rather than larger pores.

It is well known that porosity and mechanical strength are related. Ultra high performance concrete (UHPC) has about $6 \%$ porosity (28 days compressive strength of more than 20,000 psi) vs. $15 \%$ porosity for conventional concrete. Alkali silicate activated furnace slag geopolymer, for example, has less than $6 \%$ porosity and a compressive strength of about 15,000 psi after 28 days of curing [13]. The high compressive strength of our DuraLith products (12,000 to $24,000 \mathrm{psi}$ ) suggests that the porosity of the geopolymer is in the range of $6 \%$. Previous TEM studies have shown that DuraLith waste forms contain mainly isolated nanopores, e.g., $5 \mathrm{~nm}$, in the geopolymer matrix.

\subsubsection{Chemical Durability}

In this section we report results obtained from two types of chemical durability tests (TCLP and ANSI/ANS-16.1). These test were conducted with selected DuraLith formulations using samples that were cured for 28 days. Crushed 2" $\mathrm{x} 4$ " cylinders were used to prepare TCLP samples after compressive strength testing. The crushed material was used to prepare the required particle size fraction for the TCLP.

\subsubsection{Toxicity Characteristic Leaching Procedure (TCLP)}

The TCLP results are reported separately for: a) hazardous elements, $\mathrm{Cu}$, and $\mathrm{Sn}$, and b) the two elements rhenium and iodine, which represent the radionuclides ${ }^{99} \mathrm{Tc}$ and ${ }^{129} \mathrm{I}$ in the real waste.

Table 4.14 shows the results for hazardous elements, $\mathrm{Cu}$, and $\mathrm{Sn}$ for DuraLith products made with waste simulant S1 to optimize the water content, i.e., the W/C ratio (Section 4.4.1). Ten of the 19 formulations reported in Tables 4.2 and 4.4 were selected for TCLP testing. The 
first 4 samples in Table 4.14 showed surface cracks. All others were crack-free. Table 4.14 shows that surface cracking did not increase the release of hazardous elements, $\mathrm{Cu}$, and Sn. All of these elements are released at concentrations much lower than their respective EPA limits. The values for $\mathrm{Ag}$ and $\mathrm{Cr}$ are particularly low. Two other observations are that the $\mathrm{W} / \mathrm{C}$ ratio has no significant effect on the release of the hazardous elements, $\mathrm{Cu}$, and $\mathrm{Sn}$, and that there is no difference in the leaching behavior of MK- and FS-based metakaolin formulations. In summary, the five hazardous elements and $\mathrm{Cu}$, and $\mathrm{Sn}$ are strongly fixated.

Table 4.15 shows the TCLP results for DuraLith products with S2, S3, and S4-simulants; Table 4.16 shows the results for DuraLith products with enhancer combinations; Table 4.17 show the results for DuraLith products with composition variations (robustness tests); and Table 4.18 shows the results for DuraLith products with higher waste loadings. The results differ very little, if at all, from what was reported for the results in Table 4.14. Lead is the only element showing some minor but practically insignificant response to the variations in composition. The DuraLith product compositions selected for the TCLP results in Table 4.15 can be found in Table 4.3; those for Table 4.16, in Table 4.6; those for Table 4.17, in Table 4.8; and those for Table 4.18, in Table 4.10.

In the case of product S1-8X1R (Table 4.18) we have conducted a calculation assuming that DuraLith does not retain any of the chromium contained in the simulated S1 waste solution. The chromium concentration in the TCLP leachate would then be $0.85 \mathrm{mg} / \mathrm{L}$, i.e., above the EPA limit of $0.60 \mathrm{mg} / \mathrm{L}$. The actual retention capability of DuraLith decreases the chromium concentration to less than $0.01 \mathrm{mg} / \mathrm{L}$. The binder components contain small amounts of chromium as well (Table 3.3). These have not been included in the calculation of the maximum possible concentration in solution. Thus, this is a conservative estimate of the attenuation provided by the DuraLith matrix.

Next we report on TCLP results for rhenium and iodide. Table 4.19 summarizes the results for all DuraLith formulations tested.

Rhenium: The reporting limit is $0.25 \mathrm{mg} / \mathrm{L}$, which is the lowest concentration for which a reproducibility of $\pm 10 \%$ is achievable using the DCP-AES method employed at VSL. The reproducibility for concentrations that are less than $0.25 \mathrm{mg} / \mathrm{L}$ may be larger than $10 \%$.

Water optimization tests (waste S1): Leaving the first four results for the products with surface cracks S1-2X2 to S1-2X5 aside, rhenium release varies between about 16 and 28\%. Even the products with optimized water content, S2-2X12 and following in Table 4.19, fall in this range. Consequently, water optimization does not appear to have a strong effect on rhenium retention.

Varying combinations of soluble enhancers (waste S1): The results indicate that there is no significant difference between $\mathrm{SnF}_{2}$ and $\mathrm{Na}_{2} \mathrm{~S}$ as a reducing agent for rhenium (S1-2X12R1 to $\mathrm{S} 1-2 \mathrm{X} 13 \mathrm{R} 2)$. The relatively high release suggests that reduction of $\mathrm{ReO}_{4}{ }^{-}$by $\mathrm{SnF}_{2}$ to $\mathrm{Re}^{4+}$ is either limited or that dissolved oxygen in the leachant and air in the leaching vessel re-oxidizes $\mathrm{Re}^{4+}$ to $\mathrm{Re}^{7+}$. Adding cooper slag showed inconclusive results (15.4 and 5.4\% Re leached). Additional experiments would be needed to determine whether copper slag has an effect on $\mathrm{Re}$ retention. The differences between FS- based and MK-based products seem to be insignificant. 
DuraLith with wastes S2 to S4: The release values for these simulants are in the same range as for DuraLith samples with waste S1.

Higher waste loading: At higher waste loading (Table 4.9) rhenium losses vary between about 14 and $54 \%$. The number of experiments is not large enough to distinguish between release values for FS- and MK-based products.

Variation (robustness) tests: The TCLP tests were done with products at a lower Re spike concentration. This resulted in several cases in Re concentrations in the leachate being near or below the detection limit for Re. The intent of these tests was to ensure that at lower spike concentrations (and therefore close to the actual Tc concentrations of interest), there was no tendency for Re leaching to increase. This does not seem to be the case, but a more sensitive technique than DCP-AES, e.g., ICP-MS, should be used to analyze the leachants.

A systematic study of the effect of various enhancers and variations of their concentrations would be necessary to evaluate the effectiveness of such materials for reduction of $\operatorname{Re}^{7+}$.

Iodine: Analyses of iodine in leachates were conducted. There are considerable uncertainties about the iodine concentration in our DuraLith products that confound any useful interpretation of the results. In particular, we found significant iodine concentrations in leachates of samples that had not been doped with iodine. It is clear that at least some of the materials used to make DuraLith are contaminated with iodine. For example, iodine was found in $\mathrm{SnF}_{2}$. Therefore, all materials would have to be analyzed for iodine in order to estimate the degree of contamination. However, it is likely that the level of contamination is significant in comparison to the spiked level. For this reason, the iodine leachate concentrations are not reported.

\subsubsection{ANSI/ANS-16.1 Leaching Test}

Two DuraLith products (S1-2X13R2 and S1-2X14) were subjected to the ANSI/ANS16.1 leaching test. One was a MK-based product and the other was a FS-based product. The samples were selected from the series of water optimization tests, which were reported in Section 4.4.1 and shown in Tables 4.2 and 4.4. The leaching results for $\mathrm{Na}$ and $\mathrm{Re}$ are shown in Table 4.20. The leachability indices in Table 4.20 have been plotted as a function of time in Figures $4.14 \mathrm{a}, \mathrm{b}$. The calculation of the leachability indices followed the mathematical procedure described in the ANSI/ANS 16.1 document. Iodine results are not reported for reasons given in Section 4.4.7.1. The results are discussed in Section 6.

\subsubsection{Free Liquid in Cured Samples}

The test was conducted with the samples recommended for scale-up testing (Section 5). The results of the Paint Filter Liquids Test (EPA SW-846 Method 9095B) are shown in Table 4.21. No liquid free liquid was detected. 


\subsubsection{Mass Loss}

The mass loss of water during curing was measured for 26 samples. The results are shown in Table 4.22. There are 16 samples, which were prepared with $2 \mathrm{X}(2 \mathrm{M} \mathrm{Na})$ baseline waste concentration. Since curing conditions have an effect on product properties (e.g., certain samples cured in sealed bags did not develop surface cracks but did so when cured under conditions where water could escape), we have measured water loss under both conditions. As expected, samples in bags lost considerably less water than those stored in open air. Mass loss measurements have been conducted for 15 days so far (28 day-data will be provided in a revision to this report). Column 3 in Table 4.22 shows that that the mass loss due to water evaporation is relatively small during the first 24 hours in moulds. The difference becomes significant over longer periods of time. The average mass loss of $2.7 \mathrm{~g}$ after 15 days in sealed bags translates into a relative water loss of $3.8 \%$. The corresponding loss in open air was $46 \%$. Note that this difference affects DuraLith formulations whose $\mathrm{W} / \mathrm{C}$ has not been optimized (Tables 4.2 and 4.4), whereas water-optimized products are not affected and produce no surface cracks.

The water loss rate decreases when the waste loading in the product increases (compare samples ' $2 \mathrm{X}$ ' with ' $4 \mathrm{X}$ ' and ' $6 \mathrm{X}$ '). However, there is a large decrease in water loss between $2 \mathrm{X}$ and $4 \mathrm{X}$, and much less so between $4 \mathrm{X}$ and $6 \mathrm{X}$. The respective average relative water losses are $22 \%$ for the S1-4X3 samples and $17 \%$ for the S1-4X4 samples; the S1-6X3 samples lost $19 \%$. The percentages of water loss were calculated from the 15-day data in Table 4.22 and the total water in the paste (known in grams from the underlying recipes). The compositions of S1-2X26 and S1-2X27 products are shown in Table 5.1 while those for S1-4X3 and 4 and for S1-6X3 are shown in Table 4.10. The general conclusion is that water loss is slow. Even after 28 days (though the data for the present samples have not yet been obtained), as we know from previous measurements, water loss continues. The DuraLith products shown in Table 4.22 contained about $17 \%$ of water and lost roughly 20 to $50 \%$ of it in open air after 15 days. Yet crushed samples feel bone-dry even after 7 days. Therefore, the residual water is apparently present in micro- and meso-pores, from which it evaporates slowly. There is no free water, as shown by the results from the 'Paint Filter Liquids Test' in Section 4.4.8. The slow escape of water allows for continued refinement (curing) of the polymer structure, which leads to an increase in compressive strength as is known from previous work with fly ash-based geopolymers.

\subsubsection{Heat Generation}

Heat generation was assessed by monitoring the temperature of 2.5-gallon batches of selected DuraLith formulations. The early decision to work with two composite binders (metakaolin-based and blast furnace slag-based, Section 3.1) led us to make two 2.5 gallon batches with only one simulant and simulant concentration (S3) rather than one composite binder and two waste streams, S1 and S4, as proposed in the Test Plan (Stage 3B). The size was also reduced from 5 gallons to 2.5 gallons for practical reasons and schedule constraints. In view of the general similarity in the waste simulant compositions, it was agreed with PNNL that investigating the differences between the different binder compositions (the more reactive metakaolin versus the less reactive blast furnace slag) was more important than the difference in composition between S1 and S4. 


\subsubsection{Heat Production in the Activator Solution}

This measurement was conducted in the following way: A 5-gallon cylindrical metal container, about 10" diameter, was insulated with a layer of 2 " thick insulating material. A thermocouple was introduced into the waste solution, another in the middle of the insulating layer, and a third one outside to measure the ambient temperature. The thermocouples were connected to a computer, which recorded the temperature as a function of time. To prepare a batch of activator solution, $3.6 \mathrm{~kg}$ of waste simulant S3 (2 M Na) was poured into the container. Then $1.33 \mathrm{~kg} \mathrm{KOH}$ and $0.52 \mathrm{~kg} \mathrm{NaOH}$ were added in small portions under stirring. The resulting measured temperature profile is shown in Figure 4.14. Curve 1 shows the temperature in the activator solution, curve 2 in the middle of the insulating layer, and curve 3 shows the room temperature. The temperature in the activator solution rose quickly when the first portion of $\mathrm{KOH}$ was added (see the arrow on the left). The temperature was allowed to increase to about $45^{\circ} \mathrm{C}$ but was controlled not to exceed this temperature by more than about $2^{\circ} \mathrm{C}$ by adding alkali hydroxide slowly. A sudden addition of all of the alkali hydroxide would have increased the temperature to a much higher maximum temperature, which could have caused excessive loss of water in the open system. Addition of alkali hydroxide was complete after about five hours at which time the addition of $1.7 \mathrm{~kg}$ silica fume was started (second arrow in Figure 4.14). The full amount of silica fume was added within about 10 minutes. At the beginning, the temperature of the activator solution fell because the mass of the silica fume was at room temperature when it was added. The temperature then rose to $69^{\circ} \mathrm{C}$ within about 4 hours. The dissolution and formation of alkali metasilicate is a relatively slow exothermic process. The stagnation of the temperature increase for about two hours (Figure 4.14) was most likely due to poor mixing which caused solid material to accumulate in the vicinity of the thermocouple. After the addition of silica fume the container was covered and stirring was continued overnight. Covering the container may have contributed to the increase in temperature. Figure 4.14 shows that the temperature dropped within about 15 hours to below $30^{\circ} \mathrm{C}$. The ambient (room) temperature was constant near $21^{\circ} \mathrm{C}$.

As expected, preparation of an activator solution is accompanied by generation of heat. The associated temperature increase can be controlled by the rate at which alkali hydroxide and silica fume are added.

\subsubsection{Heat Production in Pastes}

The objective of these tests was to measure the rise and fall and the maximum of the temperature in FS-based and in MK-based DuraLith waste form after pouring the respective freshly mixed pastes into storage containers. The compositions of the two pastes are shown in Table 4.23a. Table 4.23b shows the chemicals and other materials used to make about $20 \mathrm{~kg}$ batches of paste of each. As for the activator test, insulation was put around and underneath the container to reduce the heat loss and better approach the conditions that would prevail in a larger sample.

In the first experiment, an activator solution based on simulant $\mathrm{S} 3(2 \mathrm{M} \mathrm{Na})$ and respective FS-based binder materials were mixed in a Lancaster Engineering K-LAB mixer, which has a 5-gallon capacity (Figure 4.15). First, the binder materials were mixed in the K-LAB mixer and then the activator was added. The mass of the dry binder needed to make 2.5 
gal of DuraLith occupied most of the space of the mixer pan, so that we ended up with a 2.5 gal batch of paste.

The paste was poured into a 5-gallon container of the same type as used in Section 4.4.10.1. About 20 minutes elapsed from the time the paste was ready to pour to the time a thermocouple was introduced into the paste. The process of pouring is shown in Figure 4.16. One thermocouple was placed in the middle of the paste, half-way down. Another thermocouple was placed into the insulation and a third thermocouple was placed outside the container to measure the room temperature. A lid was not used since it is assumed that in a large scale operation the lid of the storage container would be left open for water to escape during the 28-day curing period. The temperature was recorded after introducing the thermocouples and was continued until the temperature had dropped to near room temperature. Figure 4.17 shows the paste in the container at the beginning of the temperature measurement. The solidified product is shown in Figure 4.18. There were no cracks seen in the product. There was a very thin light grey film on the side surface, which was in contact with the container.

Figure 4.19 shows the measured temperature curves. The temperature increased as soon as the thermocouple was introduced. It took one hour for the temperature to rise to $35^{\circ} \mathrm{C}$. If we add the 20 minutes for pouring (see previous paragraph), we find that the temperature of the fresh paste remained below $35^{\circ} \mathrm{C}$ for about 80 minutes. A needle was repeatedly pushed by hand into the paste, which showed that the paste began to harden after 80 minutes. It took a total of three hours to reach the maximum temperature of $102^{\circ} \mathrm{C}$. This maximum temperature was maintained for one hour. The temperature then began to fall and reached $40^{\circ} \mathrm{C}$ after 20 hours. The temperature profile shows that the binder materials reacted relatively quickly with the activator solution. The main heat of the reaction was released within three to four hours after mixing, taking the falling temperature as an indication that the intensity of heat generation diminished.

In the second experiment, MK-based paste was made using simulant S3 (2 M Na). The procedure was the same as described above for the FS-based paste. Figure 4.20 shows the measured temperature curves.

The time to transfer the paste from the mixer into the container for temperature measurement was shorter, about 10 minutes, than in the first experiment because the paste was less viscous. Once the paste was transferred, the container was nudged from time to time to assess the flow of the paste, which showed that paste was still thin enough to be poured after 40 minutes. Thereafter, the material hardened quickly and a needle could no longer be inserted by hand without sensing significant resistance. At this time, the temperature had increased to $46^{\circ} \mathrm{C}$. After an additional $\sim 30 \mathrm{~min}$ the temperature rose to about $97^{\circ} \mathrm{C}$ and then more slowly to $107^{\circ} \mathrm{C}^{1}$. This maximum temperature was maintained for 2 hours, after which the temperature began to fall. After 20 hours the temperature had fallen to $43^{\circ} \mathrm{C}$. After the solid block was taken out of its container it was evident that there was a salt deposit on the side surface but not on the upper surface. The salt was identified as $\mathrm{KNO}_{3}$.

Table 4.24 shows some characteristic temperatures for the MK- and the FS-based pastes, which allows us to compare the pastes qualitatively. It is clear that the MK-based paste releases

\footnotetext{
1 The thermocouples were calibrated up to $100^{\circ} \mathrm{C}$. While temperatures slightly above that temperature are also expected to be reliable, it is noted that some of the measured temperatures fall outside the range of calibration by a few degrees.
} 
its heat faster than the FS-based paste. The shorter setting time of the MK-based paste suggests that the polycondensation reaction is faster in the beginning than for the FS-based paste. The maximum temperature is maintained considerably longer ( 2.5 hours) in the MK-based paste than in the FS-based paste (1 hour). This indicates that more heat generation is associated with the formation of a MK-based DuraLith than with a FS-based DuraLith. Further discussion of heat generation associated with metakaolin and blast furnace slag is provided in Section 6.

A third 2.5-gallon batch was produced with the material that was selected for recommendation for larger scale testing. The DuraLith paste was made with a more concentrated waste solution ( $\mathrm{S} 1,6 \mathrm{M} \mathrm{Na}$ ). The recommendation and selection process and the composition are reported in Section 5 but the heat release results are discussed here for comparison. Figure 4.21 shows the measured temperature curve for this sample. Three thermocouples were used as before to measure the temperature in the center of the paste, in the insulation, and the ambient temperature. A problem was encountered with the thermocouple in the insulation and therefore the respective curve is not shown in Figure 4.21. It is clear that the temperature curve representing the center of the paste is different from respective curves described above (Figures $4.19 \mathrm{a}$ and $\mathrm{b}$ and Figures 4.20a and $\mathrm{b}$ ). There was a much slower rise of temperature (compared with Figures $4.19 \mathrm{a}$ and $\mathrm{b}$ and $4.20 \mathrm{a}$ and $\mathrm{b}$ ) over 6.5 hours to a maximum temperature of $95^{\circ} \mathrm{C}$. Hardening occurred after 148 minutes and at a temperature of $32^{\circ} \mathrm{C}$ (Table 4.24). The maximum temperature was maintained for 1.25 hours, followed by a slow decrease to $40^{\circ} \mathrm{C}$ after 20 hours. Evidently, the higher waste loading and associated higher content of salts in this DuraLith formulation leads to a much slower rate of polycondensation and the observed differences in behavior in terms of heat release and temperature profile. 


\section{SECTION 5 PRODUCTS RECOMMENED FOR SCALE-UP TESTING}

The main objective of this work was to optimize previously developed DuraLith formulations for subsequent recommendation for production and testing on a larger scale. Based on the results presented in Section 4, we have selected eight candidate formulations with different waste loadings from which one final formulation is recommended for testing on a larger scale. The formulations are based on the simulated waste S1 as given in Tables 2.1 and 2.2.

\subsection{Selection Criteria}

The target chemical compositions of the pastes are shown in Table 5.1. The table shows the formulation identification in the first column. The products are ordered with increasing waste loading. There are two formulations (S1-2X26 and S1-2X27), one FS-based and one MK-based, which have a waste loading corresponding to the use of the baseline waste concentration ( $2 \mathrm{M}$ $\mathrm{Na}$ ), abbreviated as ' $2 \mathrm{X}$ ' in the sample names. Properties of the pastes and the DuraLith products are given in Table 5.2. All W/C ratios are close to the optimal values found in the water optimization tests (Table 4.4). The pastes show slightly different consistencies but they are all pourable. There was no bleeding and no salt deposits were seen after curing. The time to hardening was 65 minutes and longer (Table 5.1) indicating good workability. The cured products are crack-free. Their compressive strengths exceed 10,000 psi in all cases.

The first two formulations in Table 5.1 are very close to S1-2X12 and S1-2X13, which emerged from the water optimization study (Tables 4.2 and 4.4) as products with excellent properties. The difference in composition is that S1-2X26 and S1-2X27 contain $2 \mathrm{wt} \%$ copper slag, whereas S1-2X12 and S1-2X13 do not. Formulation S1-2X12 was used to determine its performance in the composition variation tests (robustness tests, Section 4.4.4) and was found to be insensitive to process upsets over the tested ranges.

Formulations S1-4X5 to S1-8X2R2 are all based on corresponding formulations prepared for the testing on higher waste loading (Section 4.4.5). Three DuraLith paste formulations with increased waste loadings, based on $4 \mathrm{X}, 6 \mathrm{X}$, and $8 \mathrm{X}(4 \mathrm{M}, 6 \mathrm{M}$ and $8 \mathrm{M} \mathrm{Na})$, are included in Table 5.1 as candidates for further down-selection.

All of the formulations in Table 5.1 fulfill the following requirements:

- Mixing the activator solution and the composite binder yield a homogeneous paste within 10 minutes ( $\approx 4 \mathrm{~kg}$ batch, handheld EHR23 mixer).

- The paste is readily pourable for about 40 to 90 minutes.

- There is no water separating from the paste prior to setting.

- 2" by 4" cylindrical samples in plastic moulds and covered with a lid do not show bleed water on their surface (lid had a $6 \mathrm{~mm}$ hole for water to escape). 
- $\quad$ The 2" by 4" samples do not show cracks after curing at room temperature.

- The 2" by 4" samples have a compressive strength exceeding 10,000 psi.

- No free water in the cured product ${ }^{2}$.

The chemical durability of FS- and MK-based DuraLith waste forms is similar. Hazardous elements, $\mathrm{Cu}$, and $\mathrm{Sn}$ are well retained (Section 4.4.7.1). Although significant fractions of rhenium are released under TCLP test conditions, the leachability index for rhenium exceeds the minimum value of $\mathrm{L}=9$.

The first step in the process of down-selection from these candidate formulations was to decide whether a MK-based or a FS-based formulation should be recommended. We recommend that a FS-based formulation be used for preparation and testing on a larger scale. Most of the properties of MK- and FS-based DuraLith products are very similar. However, our preference for FS is based only on the following:

- The activator solution can be made in a shorter period of time because less silica fume needs to be added than with metakaolin. The reduced amount of water in more concentrated waste solutions makes it more difficult to dissolve silica fume.

- Less heat generation is associated with setting and curing.

- The polycondensation reaction to form the geopolymer structure appears to be slower, and therefore the workability of the paste is longer. This may be of significance for larger batches, which take longer to mix and longer to pour.

- Furnace slag is less expensive than metakaolin.

- An FS-based formulation was subjected to robustness testing and performed well over the ranges tested.

This leaves us with four final candidates (Table 5.1). These formulations differ only in their waste loading. If we divide them into two groups, $(2 \mathrm{X}, 4 \mathrm{X})$ and $(6 \mathrm{X}, 8 \mathrm{X})$, then the choice would be $4 \mathrm{X}$ for the first group, because $4 \mathrm{X}$ provides excellent pastes, crack-free solids (Table 4.11) and the higher waste loading. In the second group, the choice is $6 \mathrm{X}$ because for $8 \mathrm{X}$ the possibility cannot be excluded that small amounts of salt deposits occur on the outer surface of the final product. The probability that such deposits occur on a $6 \mathrm{X}$ product is much smaller and particularly unlikely if the product is not demoulded, which is the case in a large-scale application where the waste form is poured into and remains in the disposal container.

Assuming that a product with a higher waste loading (based on $6 \mathrm{X}$ ) is preferred over a product of practically the same quality but a lower waste loading (based on $4 \mathrm{X}$ ), we recommend formulation S1-6X5 for preparation and testing on a larger scale.

The DuraLith product with the higher waste loading releases heat much more slowly, when compared with product made with $2 \mathrm{X}$ (Table 4.24). However, the time (20 hours) it takes for the temperature to return to $40^{\circ} \mathrm{C}$ is the same.

2 The DuraLith products S1-4X5 and S1-6X5 in Table 5.1 were subjected to the 'Paint Filter Liquids Test' (Table 4.21) and no water was found. Samples of all products reported in this work have been subjected to a compressive strength test after 28 days of curing. Some of the most recent samples (Table 5.1) were measured after 7 days so that results could be included in this report. The crushed material was always inspected for the presence of free water. All samples were bone-dry. 
We have prepared a 2.5-gallon (about $20 \mathrm{~kg}$ ) batch of S1-6X5 in the Lancaster Engineering K-LAB mixer to assure that no significant differences are seen during processing, compared with our small-scale process (about $4 \mathrm{~kg}$ ) where we use a hand-held EHR23 mixer. The activator/binder mix was mixed for 6 minutes. The paste was relatively dry and not easy to pour. Therefore, we adjusted the recipe for the final product, which is given also in Table 5.3.

\subsection{Recipe for the Recommended Product}

Table 5.3 shows the recipe for formulation S1-6X5-55Gal, which lists the chemicals, the quantities, and the sequence of addition to make a $545 \mathrm{~kg}$ batch.

\subsection{Instructions for Preparation}

The recipe in Section 5.2 has been written such that, roughly, a 55-gal drum can be filled. This corresponds to a mass of about $545 \mathrm{~kg}$ of DuraLith paste.

Before proceeding to this engineering-scale test, we recommend that a 4-kg sample be made using the as-received chemicals. Depending on the vendor and sometimes on the batch of the product, the compositions may vary from what we have used at VSL. For example, the river sand should have a moisture content between 2.5 and $3.5 \mathrm{wt} \%$. All ground chemicals should pass 200 mesh. The small-scale test will show whether the workability and the setting of the DuraLith paste are adequate. If it turns out that the paste is too dry or too thin, a recipe adjustment can be made so that an easily pourable paste is obtained.

Preparation of the activator solution:

1. Weigh the prescribed HSW simulant (S1 6M Na),

2. Add tin fluoride ${ }^{3}$ to the solution under stirring and keep stirring for at least two hours with a mechanical stirrer

3. Under stirring slowly add solid $\mathrm{KOH}$ and $\mathrm{NaOH}$ to the simulant solution and keep temperature below $60^{\circ} \mathrm{C}$. Continue stirring.

4. Pour silica fume into the alkaline solution while stirring

- Weigh the total mass of the activator solution after all silica fume is added. Do not interrupt stirring for at least 24 hours

- The activator solution should be thin and have little or no mud-like material on the bottom or on the edges of the container.

- Weigh the mass of the activator solution again before preparing the 55 gal sample. Compensate water loss by adding tap water if the weight loss is more than $0.2 \%$. The mass of the activator is about $210 \mathrm{~kg}$.

Further guidance is given in Sections 4.3.1 and 4.4.10, which should be consulted before preparing the activator solution.

\footnotetext{
3 Tin fluoride can be deleted without any changes in the recipe if the cost is a concern and if the purpose of the technical-scale production is only to show production feasibility.
} 
Preparation of the composite binder:

5. Weigh all ingredients (ground blast furnace slag, metakaolin, fine river sand, IONEX Ag 900 , zeolite type 5A, and copper slag) and dry mix them until a homogeneous mixture is obtained.

\section{Preparation of the paste:}

6. Pour the activator solution into the mixer. Keep mixing for about 3 minutes or until a homogeneous paste has formed.

7. Immediately add the silica fume filler and mix for another 2 minutes. Longer mixing is not recommended as the temperature may rise, which may shorten the time available for pouring. Mixing should be completed with 10 minutes.

8. Pour the DuraLith paste into the storage container. This process should be completed within 30 minutes. Do not cover.

9. Clean mixer immediately. 


\section{SECTION 6 DISCUSSION}

The present work was aimed at optimizing previously developed DuraLith formulations $[1,2,3]$ to support the recommendation of a formulation for preparation at a larger scale. The optimization process had to take into account properties related to the feasibility of the precursor components, i.e., the activator solution and the composite binder as well as the paste, which results from mixing the activator and the binder. The activator solution must be a homogeneously mixed liquid, which contains a suitable enhancer to support fixation of rhenium. The composite binder must be a homogeneous mixture of fine-grained solids, which contains a suitable enhancer to support fixation of iodide. The mixture of activator and binder, i.e., the paste, must be workable, i.e., it must be possible to pump and/or pour the paste for a sufficiently long period of time, which is compatible with process requirements. The properties of the final product, the DuraLith waste form, must comply with the waste acceptance criteria for the Integrated Disposal Facility (IDF) at Hanford. Therefore, the process of formulation optimization aims at finding an appropriate balance between ease of processing and product performance under disposal conditions. In addition, the economics of the process must be taken into consideration and therefore efforts were made to reduce overall costs associated with waste form production and disposal. This included:

- Performing all process steps (i.e., mixing and curing) without the use of heat

- Selecting low-cost starting materials (e.g., more blast furnace slag than metakaolin, addition of sand, use of silica fume from Norchem rather than $99.9 \%$ pure silica fume from Cabot)

- Increasing the waste loading, which reduces both production costs and disposal costs.

Geopolymer materials can be developed and optimized for various applications, e.g., to make fire-resistant sheets, cement and concrete for construction, or hazardous and/or radioactive waste forms. In each case, a set of composition-constraining parameters applies. These constraining parameters depend on the materials used and are ratios of chemical elements or compounds that control the polycondensation process that leads to the formation of a rigid threedimensional network structure. The constraining parameters control factors of considerable practical importance, such as the viscosity of the fresh paste and the rate at which polycondensation progresses before, during, and after hardening. Properties such as workability, bleeding, cracking, porosity, and compressive strength are affected by the constraining parameters.

A set of constraining parameter ranges for DuraLith materials has been established in previous work [1]. The ranges are shown in Table 4.1. The parameters apply to a binder, which is essentially composed of metakaolin and blast furnace slag as reactive components. Fly ash and copper slag have been used sporadically and only in relatively small fractions. The most flexible parameter and also the most important one is the $\mathrm{H}_{2} \mathrm{O} / \mathrm{M}_{2} \mathrm{O}$ molar ratio $(\mathrm{M}=\mathrm{K}, \mathrm{Na})$. Choosing a $\mathrm{H}_{2} \mathrm{O} / \mathrm{M}_{2} \mathrm{O}$ molar ratio in the given range means that the binder composition is fixed (Table 4.1). 
Variation of the mass of metakaolin or furnace slag is still possible but will affect the $\mathrm{H}_{2} \mathrm{O} / \mathrm{M}_{2} \mathrm{O}$ molar ratio.

Our strategy was to begin the process of product optimization by choosing and then varying the water content of a metakaolin-based DuraLith formulation. We recalculated the $\mathrm{H}_{2} \mathrm{O} / \mathrm{M}_{2} \mathrm{O}$ molar ratio as a mass ratio and included the masses of metakaolin and furnace slag, (furnace slag includes here the sum of the masses of furnace slag, fly ash, and copper slag), silica fume, and the enhancer Ag-zeolite. This yielded the more practical ratio 'W/C', which we used throughout this report. In all of the samples investigated in the present work all of the water is provided by the simulated waste solution and no additional water was required.

Selecting a $\mathrm{W} / \mathrm{C}$ ratio within the range given in Table 4.1 ensures that a mixture of activator and binder materials will yield a paste that undergoes polycondensation and formation of a solid geopolymer. This is a necessary but insufficient condition. The properties of the paste (Table 4.4) and the speed of setting and hardening also depends on

- The types and amounts of other constituents of the paste such as enhancers, fly ash, copper slag, waste solids, and sand

- Impurities such as carbon in silica fume

- The sequence of addition (e.g., whether all silica fume is added to the activator solution or whether some of it is added while the activator is mixed with the binder materials).

The specific mix of binder materials, dissolved chemicals, and water also determines whether bleeding will be observed during hardening, whether deposits form on the surface, and whether the product shrinks, swells, and/or cracks during curing. The rate at which water evaporates from the hardening material, particularly during the first day or two also plays role.

The first selected W/C mass ratio was 0.365 , which yielded a good paste but final products with fine cracks throughout the entire surface (Table 4.4). Slowing the rate of water evaporation helped when the moulds with freshly made, hardened paste were wrapped in paper in plastic bags and then cured at room temperature for at least two weeks before opening the bags, or the freshly made paste was cured in moulds at higher temperature, e.g., at $50^{\circ} \mathrm{C}$. Under these conditions all samples were crack-free. Exchanging the carbon contaminated silica fume from Norchem for a more expensive clean product from Carbot did not help (Table 4.2, formulation $\mathrm{S} 1-2 \mathrm{X} 2 \mathrm{~A}$ ). Lowering the $\mathrm{W} / \mathrm{C}$ ratio considerably to 0.319 still yielded a product with surface cracks (Table 4.2, formulation S1-2X2A). The initial formulations based on the furnace slag-based DuraLith from previous work [1] (see S1-2X5, Table 4.4) were cracked as much as the metakaolin-base product and slowing water evaporation helped as before.

Finally, a water/solids ratio (W/C) of close to 0.300 for metakaolin- and of close to 0.275 for furnace slag-based formulations yielded the desirable products, which were crack-free when cured at room temperature and insensitive to the rate at which water was allowed to evaporate (open lid, lid with a hole, wrapped in plastic).

Based on these findings, the balance of the work began with formulations S1-2X10R and S1-2X11R (Tables 4.3 and 4.4). Water optimization turned out to be so successful that all subsequent formulation variants yielded products that were satisfactory with respect to desirable physical properties of the paste and of the solid waste forms (leaching is discussed separately, below). Formulation variants comprised: 
- Use of the other simulated wastes (S2, S3, and S4) - (Table 4.5)

- Use of various enhancer combinations and additives such as fly ash and copper slag (Table 4.7)

- Intentional variations of the activator and binder compositions (robustness tests - Table 4.9)

- Increase of waste loading up to about six times the $\mathrm{S} 1$ base line waste (Tables 4.11, 4.13)

In summary, these results gave confidence that a DuraLith paste can be made with properties that satisfy production-related needs such as:

- Short mixing time to obtain a homogeneous paste that does not contain free water or lumps

- Sufficiently long workability (mixing, pumping, pouring)

- No bleeding, no cracks, no significant shrinkage or swelling, no or negligibly small deposits on the surface.

With respect to disposal in the IDF, the principal requirements on the waste form are that it shall:

- Not contain free water as defined in SW-846 Method 9095 (Paint Filter Liquids Test)

- Have a compressive strength of greater than 500 psi (>3.54 MPa) when tested according to ASTM C39/C39M

- Have a leachability index for sodium of greater 6.0 and for technetium of greater than 9.0 .

The 'free water test' was conducted with two products and no free water was found, as expected. Compressive strength measurements were performed on all samples and the minimum value of 500 psi was exceeded by at least a factor of 20 . Thus, the more constraining factor is the chemical durability, which is discussed next.

Chemical durability is controlled by the diffusivity of the fraction of mobile species in the pores of the solid DuraLith Waste forms. Pore size tends to decrease with increasing compressive strength. From this perspective, one would expect that products with high strength would tend to have higher chemical durability, particular for sodium for which no specific sequestering agents were employed. Retention of technetium (in this work rhenium) and of the iodide anion can be supported by adding enhancers to the waste form constituents. These enhancers are expected to precipitate rhenium as $\mathrm{ReO}_{2}$ and iodide as $\mathrm{AgI}$. We have conducted studies with various enhancers and enhancer combinations (Table 4.7) but we have not systematically varied enhancer types and ratios and concentrations in the waste form. This would require a separate study using the product recommended for larger scale testing (S1-6X5, Table $5.1)$.

In the present work, chemical durability was measured using the TCLP and the ANSI/ANS-16.1 methods. In addition to sodium and rhenium, iodide, the hazardous elements $\mathrm{Ag}, \mathrm{As}, \mathrm{Cd}, \mathrm{Cr}, \mathrm{Pb}$, and $\mathrm{Cu}$, and $\mathrm{Sn}$ were measured. The result was that the group of $\mathrm{Ag}, \mathrm{As}, \mathrm{Cd}$, 
$\mathrm{Cr}, \mathrm{Cu}, \mathrm{Pb}$, and $\mathrm{Sn}$ showed very low leachability for all of the products studied in this work compared with applicable EPA concentration limits. However, significant fractions of rhenium were released under TCLP test conditions (Section 4.4.7.1). This may either be due to insufficient reduction by the enhancers $\mathrm{SnF}_{2}$ and $\mathrm{Na}_{2} \mathrm{~S}$ or to re-oxidation because of the relatively large exposed surface area.

Testing under ANSI/ANS-16.1 conditions, which likely are closer to disposal conditions, produces considerably lower concentrations of Re in the leachates. Thus, for analytical reasons the rhenium concentration had to be increased significantly (from about $2 \mathrm{mg} / \mathrm{L} \mathrm{Tc}$ to $135 \mathrm{mg} / \mathrm{L}$ Re). Unfortunately, however, if the efficiency of the enhancer were not very high, a fraction of Re higher than the total concentration of Tc in the real case could remain mobile in the solid and could be leached out. Additional testing would be needed to assess the extent of this effect. At the realistic Re (Tc) concentration, the mass of Re not fixated by the enhancer would likely be much smaller and it is possible that higher leachability indices would be measured than those obtained for the higher spike level. Despite the high spike levels, the measured Re concentrations are very low and close to the detection limit (and below our reporting limit). Re-analysis using a method with lower detection limit would be helpful in this regard. Based on a typical reporting limit of $5 \mu \mathrm{g} / \mathrm{L}$, ICP-MS would have allowed us to measure a leachability factor of about 10 , given the Re concentration in our samples. Our results show (Table 4.20) that the leachability index is about 9, indicating that both DuraLith products meet the minimum leachability index of 9 for rhenium. The FS-based DuraLith shows two leachability indices below 9 in the short-term. However, in the longer term between 20 and 90 days, the leachability index stabilizes slightly above 9. Ideally, however, leachability indices should be measured by using ${ }^{99} \mathrm{Tc}$ as was done in reference [3]. In the case of iodine, the short-lived isotope ${ }^{131}$ I could be used. This would avoid the contamination problem reported in Sections 4.4.7.1 and 4.4.7.2.

The process of making geopolymers is associated with the generation of heat. Heat is generated when making the activator (Figure 4.14) and when the activator is mixed with the composite binder (Figures 4.19a,b and 4.20a,b, Figure 4.21). The amount of heat and the rate at which it is released depend on the composition of the waste and the binder. Excessive heat generation can lead to thermal stress, which may cause cracking of the products and may impact performance properties [14].

There is an extensive body of literature dealing with heat evolution during alkali activation of pozzolans, hydration of cement, as well as cementitious waste forms. As far as waste forms are concerned, Harbour et al. [14 - 17] studied heat evolution during curing of saltstone mixes using isothermal calorimetry. The authors found that a mixture of ground granulated blast furnace slag (GGBFS) and a solvent extraction unit waste simulant generates about $250 \mathrm{~J} / \mathrm{g}$, comparable to a mixture of Portland cement and with the same simulant. The actual binder for saltstone is composed of $10 \%$ Portland cement, $45 \%$ blast furnace slag and $45 \%$ fly ash. The mixture of this binder and with the same simulant $\left(\mathrm{W} / \mathrm{C}=0.6,25{ }^{\circ} \mathrm{C}, 7\right.$ days) generates significantly less heat at $120 \mathrm{~J} / \mathrm{g}$, while a mixture with fly ash Class $\mathrm{F}$ generates even less at only $7 \mathrm{~J} / \mathrm{g}\left(\mathrm{W} / \mathrm{C}=0.6,25{ }^{\circ} \mathrm{C}, 7\right.$ days). Kumar et al. [17] measured about $15 \mathrm{~J} / \mathrm{g}$ for pure fly ash compared to about $135 \mathrm{~J} / \mathrm{g}$ for pure furnace slag $\left(27^{\circ} \mathrm{C}\right.$ for 48 hours; isothermal conductance calorimetry). Granizo et al. [18] studied heat release during alkali-activation of metakaolin $(\mathrm{MK})$ in $12 \mathrm{M} \mathrm{NaOH}$ with a solution to $\mathrm{MK}$ ratio $=3-7\left(45^{\circ} \mathrm{C}, 50\right.$ hours) and found values ranging from 232 to $434 \mathrm{~J} / \mathrm{g}$ with maximum temperatures reached between 3-4 hours, indicating higher heat release than with furnace slag. Higher heat release from metakaolin than 
furnace slag was also reported by Buchwald et al. [19]. The findings for MK and FS heat generation are in qualitative agreement with our findings (Figures 4.19a and $\mathrm{b}$ and $4.20 \mathrm{a}$ and $\mathrm{b}$.

The current DuraLith formulations use significant amounts of furnace slag and metakaolin as well as high content alkali hydroxide (e.g., 12 to 15 moles/L alkali hydroxide). Therefore, heat generation is expected to be significant. This effect enhances the curing process and shortens the setting time. In our experimental set-up, temperatures increased up to $\sim 100^{\circ} \mathrm{C}$ but did not lead to cracking. Lower temperatures can be achieved, if necessary, by using fly ash-based DuraLith waste form compositions. Preliminary testing with fly ash-based DuraLith waste forms shows that significant heat reduction can be achieved due to the low heat generation during alkali-activation of fly ash Class F. 


\section{SECTION 7 CONCLUSIONS}

The present work was successful in optimizing previously developed DuraLith formulations $[1,2,3]$ to support the selection of a formulation for preparation at a larger scale. The recommended formulation and preparation procedure are presented in Sections 5.2 and 5.3. The principal conclusions from this work include:

- The water-to-solids ratio must be optimized because it affects many of the properties of a DuraLith waste form.

- Optimal water-to-solids ratios were found for metakaolin- and furnace slag-based DuraLith formulations.

- The optimal water-to-solids ratios can be used within narrow limits to make DuraLith waste forms with significantly higher waste loadings than that corresponding to the baseline $(2 \mathrm{M} \mathrm{Na})$.

- Based on an overall evaluation of all measured properties related to processing and disposal we attribute a slightly better performance to the furnace slag-based DuraLith waste forms.

- From several furnace slag-based candidate waste forms we have selected one for production at a larger scale. This product contains the simulated waste S1 (Table 2.1). The waste loading is roughly three times as high as in a DuraLith product that contains waste with baseline concentration (Table 2.2), i.e., nearly the same volume of waste was used but at three times the concentration as that in Table 2.2.

- All optimized compositions were crack-free, did not bleed, and showed high compressive strength.

- Based on the early data, the chemical durability exceeds the minimum leachability indices for $\mathrm{Na}$ and $\mathrm{Re}$ but the tests are still ongoing. However, leaching results for iodide were confounded by an apparent iodine contamination in the raw materials and could not be reported.

- Hazardous elements and $\mathrm{Cu}$ and $\mathrm{Sn}$ are very well retained in the DuraLith waste forms. Measured values are much lower than applicable EPA limits.

- Heat is produced during preparation of the activator solution. The temperature increase can be controlled by the rate at which alkali hydroxide and silica fume are added to the waste solution.

- Heat is generated after the activator is mixed with the composite binder. A significant increase of temperature was observed in a 2.5-gallon batch in an insulated container beginning shortly after pouring (Figures $4.19 \mathrm{a}$ and $\mathrm{b}$ and $4.20 \mathrm{a}$ and $\mathrm{b}$ ). For the furnace slag based sample, the maximum temperature was $102^{\circ} \mathrm{C}$. The temperature began to fall after remaining at that value for about one hour and returned to near ambient within about 20 hours. Cooling may be necessary if much larger containers are used than in this study. 
- The preparation of the activator solution affects both the properties of the DuraLith paste (activator-binder mixture) and the properties of the final product. It is important that the silica source, in this case fumed silica, is completely dissolved. In the case of fumed silica, the liquid is black (due to carbon contamination) and the extent to which the fumed silica has been dissolved cannot be seen easily. Therefore, the activator should be stirred for 48 hours or until it yields a liquid that can be poured as easily as olive oil.

- If heat generation is a problem in a larger scale application, instead of cooling, substantial fractions of metakaolin and furnace slag could be replaced by fly ash Class F. The use of fly ash Class $\mathrm{F}$ is associated with much less generation of heat.

- Tables 4.10, 4.11 and 5.1, 5.2 show that a few samples were made with very high waste loading (12X and $8 \mathrm{X}$, respectively). These samples have not been recommended for larger scale production because product characterization was less advanced than with $6 \mathrm{X}$ samples. However, we find that the $12 \mathrm{X}$ DuraLith waste form fulfills all desirable production requirements. Final qualification would require results from TCLP and ANS 16.1 leaching tests, which could not be conducted within the time frame of the present project.

- Any residual generation of hydrogen during activator preparation can be eliminated, if necessary, by substituting the fumed silica, which contains some elemental silicon, by potassium silicate glass powder or pretreated fumed silica. Both products are commercially available at a slightly higher price. 


\section{SECTION 8 REFERENCES}

[1] "Low Temperature Waste Immobilization Testing," R.L. Russell, M.J. Schwinger, J.H. Westsik, P.R. Harm, and D.E. Smith, PNNL-16052, Rev. 1, Pacific Northwest National Laboratory, Richland, Washington, 2006.

[2] "DuraLith Low Temperature Waste Forms," W. Gong, W. Lutze, M. Chaudhuri, H. Gan, G.A. Diener, and I.L. Pegg, VSL-05R5150-1, Rev. 1, Vitreous State Laboratory, The Catholic University of America, Washington, DC, 3/24/06.

[3] "Secondary Waste Form Screening Test Results - Cast Stone and Alkali AluminoSilicate Geopolymer," E.M. Pierce, K.J. Cantrell, J.H. Westsik, Jnr., K.E. Parker, W. Um, M.M Valenta, and R.J. Serne, PNNL-19505, Pacific Northwest National Laboratory, Richland, WA, 2010.

[4] "DuraLith Alkali-Aluminosilicate Geopolymer Waste Form Testing for Hanford Secondary Waste", Test Plan, VSL-10T2140-1, Rev. 0, Vitreous State Laboratory, The Catholic University of America, Washington, DC, 8/2/10,

[5] "Activation of Ground Blast Furnace Slag by Alkali-Metal and Alkaline-Earth Hydroxides," A. Roy, P.J. Shilling, H.C. Eaton, P.G. Malone, W.N. Brabston, and L.D. Wakeley, J. Am. Ceram. Soc., 75, 3233 (1992).

[6] "The Characterization of Hardened Alkali-Activated Blast Furnace Slag Pastes and the Nature of the Calcium Silicate Hydrate (C-S-H) Phase, I.G. Richardson, A.R. Brough, G.W. Grooves, and C.M. Dobson, Cem. Conr. Res., 24, 813 (1994).

[7] "Hydration Products of Alkali-Activated Slag Cement," S.D. Wang and K.L. Scrivener, Cem. Conr. Res., 25, 561 (1995).

[8] "Sodium Silicate-Based, Alkali-Activated Slag Cement," A.R. Brough and A. Atkinson, Cem. Concr. Res., 32, 813 (2002).

[9] "Hydration Products and Reactivity of Blast-Furnace Slag Activated by Various Alkali," J.I. Escalante-Garcia, A.F. Fuentes, A. Gorokhovsky, P.E. Fraire-Luna, and G. MendozaSuarez, J. Am Ceram. Soc., 86, 2148 (2003).

[10] "Determination of Free Silicon Content in Silica Fume and its Effect on Volume of Gas Released from Mortars Incorporating Silica Fume," NM.H. Zhang, V.M. Malhotra, and J. Wolsiefer, Sr., ACI Mat. J. 97 (2000) 576-586.

[11] "Portland-Cement Concrete Rheology and Workability," G.S. Wong, A.M. Alexander, R. Haskins, T.S. Poole, P.G. Malone, and L. Wakeley, Final Report, Publication No. FHWA-RD-00-025, Federal Highway Administration, 2001. 
[12] "Microstructure of Geopolymer Materials Based on Fly Ash" F. Skvara, L. Kopecky, J. Nemecek, and Z. Bittnar, Ceramics - Silikaty 50 (4) 208-215 (2006).

[13] "Effectiveness of Mixing Time on Hardened Properties of Waterglass-Activated Slag Pastes and Mortars," M. Palacios and F. Puertas, ACI Mat. J. 108 (2011) 73-78.

[14] "Heat of Hydration of Saltstone Mixes - Measurement by Isothermal Calorimetry", J.R. Harbor, V.J. Williams, and T.B. Edward, WSRC-STI-2007-00263, Rev. 0, Aiken, SC, May 2007.

[15] "Performance Properties of Saltstone Produced Using SWPF Simulants", J.R. Harbour and T.B. Edwards, SRNL-STI-2009-00810, Rev. 0, Aiken, SC, December 2009.

[16] "Measurement of Specific Heat Capacity of Saltstone", J.R. Harbour and T.B. Edwards, SRNS-STI-2008-00102, Rev. 0, Aiken SC, September 2008.

[17] "Influence of the Starting Kaolin on Alkali-Activated Materials Based on Metakaolin. Study of the reaction Parameters by Isothermal Conduction Calorimetry", M.L. Granizo, M.T. Blanko-Varela, and A. Palomo, J. Mat. Sci. 35 (2000) 6309-6315.

[18] "Influence of Granulated Blast Furnace Slag on the Reaction, Structure and Properties of Fly Ash Based Geopolymer”, S. Kumar, R. Kumar, and S.P. Mehrotra, J. Mat. Sci. 45 (2010) 607-615.

[19] "Reaction Progress of Alkaline-Activated Metakaolin-Ground Granulated Blast Furnace Slag Blends", A. Buchwald, R. Tarin, and D. Stephan, J. Mat. Sci. 44 (2009) 5609-5617.

[20] 40 CRF 268.48 Appendix F, Universal Treatment Standards (UTS), Engineering Design File, Inorganic Constituents, Nonwastewater Standard, 10/19/2000, Rev. 0 
Table 2.1. Hanford Secondary Waste Composition (Moles/Liter).

\begin{tabular}{|c|c|c|c|c|}
\hline HSW & S1 & $\mathrm{S} 2$ & S3 & S4 \\
\hline- & \multicolumn{3}{|c|}{ Caustic Scrubber } & \multirow{2}{*}{ Caustic Scrubber /SBS Blend } \\
\hline Component & Baseline & Low $\mathrm{NO}_{3}^{-} \& \mathrm{Cl}^{-}$ & High $\mathrm{NO}_{3}^{-} \& \mathrm{Cl}^{-}$ & \\
\hline $\mathrm{Na}$ & 1 & 1 & 1 & 1 \\
\hline $\mathrm{Al}(\mathrm{OH})_{3}$ & $9.39 \mathrm{E}-02$ & $1.14 \mathrm{E}-01$ & 9.22E-02 & 4.24E-02 \\
\hline $\mathrm{Si}$ & 1.88E-03 & 2.04E-03 & 7.74E-04 & 1.39E-02 \\
\hline $\mathrm{K}$ & 5.82E-04 & $6.51 \mathrm{E}-04$ & 2.18E-03 & 2.87E-02 \\
\hline $\mathrm{NH}_{4}^{+}$ & - & - & - & $4.41 \mathrm{E}-01$ \\
\hline $\mathrm{OH}^{-}$ & 3.98E-01 & 4.35E-01 & 2.45E-01 & $1.02 \mathrm{E}-08$ \\
\hline $\mathrm{NO}_{3}^{-}$ & 3.28E-01 & $1.90 \mathrm{E}-01$ & 3.97E-01 & $1.13 \mathrm{E}+00$ \\
\hline $\mathrm{CO}_{3}^{-2}$ & $2.28 \mathrm{E}-02$ & $4.66 \mathrm{E}-02$ & $3.94 \mathrm{E}-02$ & $1.04 \mathrm{E}-02$ \\
\hline $\mathrm{Cl}^{-}$ & 2.25E-02 & 2.17E-02 & 2.91E-02 & $1.04 \mathrm{E}-02$ \\
\hline $\mathrm{NO}_{2}^{-}$ & $1.20 \mathrm{E}-02$ & $1.05 \mathrm{E}-02$ & 3.83E-02 & $4.31 \mathrm{E}-02$ \\
\hline $\mathrm{PO}_{4}^{-3}$ & 6.87E-03 & 4.85E-03 & 6.03E-03 & $5.10 \mathrm{E}-03$ \\
\hline $\mathrm{SO}_{4}^{-2}$ & $4.41 \mathrm{E}-03$ & $5.81 \mathrm{E}-03$ & $5.14 \mathrm{E}-03$ & $4.36 \mathrm{E}-02$ \\
\hline $\mathrm{F}^{-}$ & 5.57E-04 & $3.75 \mathrm{E}-04$ & $4.42 \mathrm{E}-04$ & $1.02 \mathrm{E}-08$ \\
\hline $\mathrm{Cr}$ & 2.03E-04 & 2.03E-04 & 2.03E-04 & $1.09 \mathrm{E}-03$ \\
\hline $\mathrm{Ag}$ & 6.27E-06 & $6.27 \mathrm{E}-06$ & 6.27E-06 & $2.35 \mathrm{E}-05$ \\
\hline As & 3.48E-05 & $3.48 \mathrm{E}-05$ & 3.48E-05 & $1.61 \mathrm{E}-05$ \\
\hline $\mathrm{Cd}$ & $1.57 \mathrm{E}-06$ & $1.57 \mathrm{E}-06$ & $1.57 \mathrm{E}-06$ & $2.16 \mathrm{E}-05$ \\
\hline $\mathrm{Hg}$ & 1.13E-05 & $1.13 \mathrm{E}-05$ & 1.13E-05 & $5.30 \mathrm{E}-06$ \\
\hline $\mathrm{Pb}$ & 8.99E-06 & 8.99E-06 & 8.99E-06 & 8.28E-06 \\
\hline Tc & $1.81 \mathrm{E}-05$ & $1.81 \mathrm{E}-05$ & $1.81 \mathrm{E}-05$ & 5.59E-04 \\
\hline $\mathrm{I}$ & 4.62E-06 & 4.62E-06 & 4.62E-06 & $6.29 \mathrm{E}-05$ \\
\hline TOC & 9.39E-02 & $1.14 \mathrm{E}-01$ & 9.22E-02 & 4.24E-02 \\
\hline
\end{tabular}

TOC = total organic carbon

"-" Empty data field 
Table 2.2. Chemicals and Masses for 15 liters HSW S1 Simulant (2 M Na).

\begin{tabular}{|c|c|c|c|c|c|c|}
\hline $\begin{array}{l}\text { Order of } \\
\text { Addition }\end{array}$ & Analyte & $\begin{array}{c}\text { Target } \\
\text { Moles/L }\end{array}$ & Reagent & $\begin{array}{l}\text { Molecular } \\
\text { Weight }\end{array}$ & Assay & $\begin{array}{c}\text { Target } \\
\text { Mass (g) }\end{array}$ \\
\hline 1 & Ag & 1.3E-05 & $\mathrm{AgNO}_{3}$ & 169.89 & 0.999 & 0.032 \\
\hline 1 & As & $6.96 \mathrm{E}-05$ & $\mathrm{Na}_{2} \mathrm{HAsO}_{4} \cdot 7 \mathrm{H}_{2} \mathrm{O}$ & 312.01364 & 1.000 & 0.326 \\
\hline 1 & $\mathrm{Al}$ & $1.88 \mathrm{E}-01$ & $\mathrm{Al}(\mathrm{OH})_{3}$ & 78.003558 & 0.990 & 221.838 \\
\hline 1 & $\mathrm{Cd}$ & $3.14 \mathrm{E}-06$ & $\mathrm{Cd}\left(\mathrm{NO}_{3}\right)_{2} \cdot 4 \mathrm{H}_{2} \mathrm{O}$ & 308.48 & 0.985 & 0.015 \\
\hline 1 & $\mathrm{CO}_{3}{ }^{2-}$ & 4.56E-02 & $\mathrm{Na}_{2} \mathrm{CO}_{3}$ & 105.98844 & 1.000 & 72.472 \\
\hline 1 & $\mathrm{Cr}$ & 4.06E-04 & $\mathrm{Na}_{2} \mathrm{Cr}_{2} \mathrm{O}_{7} \cdot 2 \mathrm{H}_{2} \mathrm{O}$ & 297.9981 & 0.990 & 1.832 \\
\hline 1 & $\mathrm{Hg}$ & $2.26 \mathrm{E}-05$ & $\mathrm{Hg}\left(\mathrm{NO}_{3}\right)_{2} \cdot \mathrm{H}_{2} \mathrm{O}$ & 342.62 & 0.980 & 0.118 \\
\hline 1 & $\mathrm{PO}_{4}^{3-}$ & $1.37 \mathrm{E}-02$ & $\mathrm{Na}_{2} \mathrm{HPO}_{4} \cdot 7 \mathrm{H}_{2} \mathrm{O}$ & 267.9818 & 0.990 & 55.759 \\
\hline 1 & $\mathrm{Si}$ & $3.76 \mathrm{E}-03$ & $\mathrm{Na}_{2} \mathrm{SiO}_{3}$ & 122.06324 & 0.980 & 7.021 \\
\hline 1 & $\mathrm{SO}_{4}^{2-}$ & 8.82E-03 & $\mathrm{Na}_{2} \mathrm{SO}_{4}$ & 142.0376 & 0.990 & 18.971 \\
\hline 1 & $\mathrm{NO}_{3}^{-}$ & $6.56 \mathrm{E}-01$ & $\mathrm{NaNO}_{3}$ & 84.99471 & 0.980 & 851.318 \\
\hline 1 & $\mathrm{NO}_{2}^{-}$ & 2.40E-02 & $\mathrm{NaNO}_{2}$ & 68.99527 & 0.980 & 25.332 \\
\hline 1 & $\mathrm{Cl}^{-}$ & 4.50E-02 & $\mathrm{NaCl}$ & 58.44277 & 0.980 & 40.233 \\
\hline 1 & $\mathrm{~F}^{-}$ & $1.11 \mathrm{E}-03$ & $\mathrm{NaF}$ & 40.41257 & 0.990 & 0.682 \\
\hline 3 & $\mathrm{OH}^{-}$ & 7.94E-01 & $\mathrm{NaOH}$ & 40.01 & 0.987 & 482.784 \\
\hline 1 & $\mathrm{~K}$ & $1.17 \mathrm{E}-03$ & $\mathrm{KNO}_{3}$ & 101.1032 & 0.990 & 1.785 \\
\hline 1 & $\mathrm{~Pb}$ & $1.80 \mathrm{E}-05$ & $\mathrm{~Pb}\left(\mathrm{NO}_{3}\right)_{2}$ & 331.21 & 0.990 & 0.090 \\
\hline 1 & TOC & $1.67 \mathrm{E}-01$ & $\mathrm{Na}_{2} \mathrm{C}_{2} \mathrm{O}_{4}$ & 134 & 0.980 & 343.056 \\
\hline 1 & TOC & 2.05E-02 & Oxalic acid dihydrate & 126.07 & 0.980 & 39.440 \\
\hline 4 & $\mathrm{I}$ & 7.88E-04 & $\mathrm{NaI}$ & 149.89 & 0.999 & 1.773 \\
\hline 4 & $\operatorname{Re}$ & 7.25E-04 & $\mathrm{HReO}_{4}$ & - & 0.562 & 3.601 \\
\hline 2 & $\mathrm{H}_{2} \mathrm{O}$ & $5.29 \mathrm{E}+01$ & $\mathrm{H}_{2} \mathrm{O}$ & 18.01528 & 1.000 & 14288.127 \\
\hline \multicolumn{5}{|c|}{ Spiking level: $\mathrm{Re}=135 \mathrm{mg} / \mathrm{L} ; \mathrm{I}=100 \mathrm{mg} / \mathrm{L}$} & Total & 16456.610 \\
\hline
\end{tabular}


Table 2.3. Chemicals and Masses for 10 liters HSW S1 Simulant (8 M Na).

\begin{tabular}{|c|c|c|c|c|c|c|}
\hline $\begin{array}{l}\text { Order of } \\
\text { addition }\end{array}$ & Analyte & $\begin{array}{c}\text { Target } \\
\text { Moles/L }\end{array}$ & Reagent & $\begin{array}{c}\text { Molecular } \\
\text { Weight }\end{array}$ & Assay & $\begin{array}{c}\text { Target } \\
\text { Mass (g) }\end{array}$ \\
\hline 1 & $\mathrm{Ag}$ & 5.00E-05 & $\mathrm{AgNO}_{3}$ & 169.89 & 0.999 & 0.085 \\
\hline 1 & As & $2.78 \mathrm{E}-04$ & $\mathrm{Na}_{2} \mathrm{HAsO}_{4} \cdot 7 \mathrm{H}_{2} \mathrm{O}$ & 312.01364 & 1.000 & 0.869 \\
\hline 1 & $\mathrm{Al}$ & $7.51 \mathrm{E}-01$ & $\mathrm{Al}(\mathrm{OH})_{3}$ & 78.003558 & 0.765 & 765.965 \\
\hline 1 & $\mathrm{Cd}$ & $1.26 \mathrm{E}-05$ & $\mathrm{Cd}\left(\mathrm{NO}_{3}\right)_{2} \cdot 4 \mathrm{H}_{2} \mathrm{O}$ & 308.48 & 0.985 & 0.039 \\
\hline 1 & $\mathrm{CO}_{3}{ }^{2-}$ & $1.82 \mathrm{E}-01$ & $\mathrm{Na}_{2} \mathrm{CO}_{3}$ & 105.98844 & 1.000 & 193.362 \\
\hline 1 & $\mathrm{Cr}$ & $1.62 \mathrm{E}-03$ & $\mathrm{Na}_{2} \mathrm{Cr}_{2} \mathrm{O}_{7} \cdot 2 \mathrm{H}_{2} \mathrm{O}$ & 297.9981 & 0.990 & 4.888 \\
\hline 1 & $\mathrm{Hg}$ & 9.04E-05 & $\mathrm{Hg}\left(\mathrm{NO}_{3}\right)_{2} \cdot \mathrm{H}_{2} \mathrm{O}$ & 342.62 & 0.980 & 0.316 \\
\hline 1 & $\mathrm{PO}_{4}^{3-}$ & $5.50 \mathrm{E}-02$ & $\mathrm{Na}_{2} \mathrm{HPO}_{4} \cdot 7 \mathrm{H}_{2} \mathrm{O}$ & 267.9818 & 0.990 & 148.771 \\
\hline 1 & $\mathrm{Si}$ & $1.50 \mathrm{E}-02$ & $\mathrm{Na}_{2} \mathrm{SiO}_{3}$ & 122.06324 & 0.980 & 18.733 \\
\hline 1 & $\mathrm{SO}_{4}{ }^{2-}$ & 3.53E-02 & $\mathrm{Na}_{2} \mathrm{SO}_{4}$ & 142.0376 & 0.990 & 50.617 \\
\hline 1 & $\mathrm{NO}_{3}^{-}$ & $2.62 \mathrm{E}+00$ & $\mathrm{NaNO}_{3}$ & 84.99471 & 0.980 & 2271.386 \\
\hline 1 & $\mathrm{NO}_{2}^{-}$ & $9.60 \mathrm{E}-02$ & $\mathrm{NaNO}_{2}$ & 68.99527 & 0.980 & 67.587 \\
\hline 1 & $\mathrm{Cl}^{-}$ & $1.80 \mathrm{E}-01$ & $\mathrm{NaCl}$ & 58.44277 & 0.980 & 107.344 \\
\hline 1 & $\mathrm{~F}^{-}$ & $4.46 \mathrm{E}-03$ & $\mathrm{NaF}$ & 40.41257 & 0.990 & 1.819 \\
\hline 3 & $\mathrm{OH}^{-}$ & $3.18 \mathrm{E}+00$ & $\mathrm{NaOH}$ & 40.01 & 0.987 & 1288.108 \\
\hline 1 & $\mathrm{~K}$ & 4.66E-03 & $\mathrm{KNO}_{3}$ & 101.1032 & 0.990 & 4.763 \\
\hline 1 & $\mathrm{~Pb}$ & 7.19E-05 & $\mathrm{Pb}\left(\mathrm{NO}_{3}\right)_{2}$ & 331.21 & 0.990 & 0.241 \\
\hline 1 & TOC & $6.70 \mathrm{E}-01$ & $\mathrm{Na}_{2} \mathrm{C}_{2} \mathrm{O}_{4}$ & 134 & 0.980 & 916.123 \\
\hline 1 & TOC & $8.12 \mathrm{E}-02$ & Oxalic acid dihydrate & 126.07 & 0.980 & 104.458 \\
\hline 4 & $\mathrm{I}$ & 3.94E-04 & $\mathrm{NaI}$ & 149.89 & 0.999 & 0.591 \\
\hline 4 & $\mathrm{Re}$ & 2.69E-04 & $\mathrm{HReO}_{4}$ & - & 0.562 & 0.890 \\
\hline 2 & $\mathrm{H}_{2} \mathrm{O}$ & - & $\mathrm{H}_{2} \mathrm{O}$ & 18.01528 & 1.000 & 7704.104 \\
\hline \multicolumn{5}{|c|}{ Spiking level: $\mathrm{Re}=50 \mathrm{mg} / \mathrm{L} ; \mathrm{I}=50 \mathrm{mg} / \mathrm{L}$} & Total & 13651.059 \\
\hline
\end{tabular}


Table 2.4. Chemicals and Masses for 5 liters HSW S1 Simulant (12 M Na).

\begin{tabular}{|c|c|c|c|c|c|c|}
\hline $\begin{array}{l}\text { Order of } \\
\text { Addition }\end{array}$ & Analyte & $\begin{array}{c}\text { Target } \\
\text { Moles/L }\end{array}$ & Reagent & $\begin{array}{l}\text { Molecular } \\
\text { Weight }\end{array}$ & Assay & $\begin{array}{c}\text { Target } \\
\text { Mass (g) }\end{array}$ \\
\hline 1 & $\mathrm{Ag}$ & $7.50+\mathrm{E}-05$ & $\mathrm{AgNO}_{3}$ & 169.89 & 0.999 & 0.064 \\
\hline 1 & As & $4.18 \mathrm{E}-04$ & $\mathrm{Na}_{2} \mathrm{HAsO}_{4} \cdot 7 \mathrm{H}_{2} \mathrm{O}$ & 312.01364 & 1.000 & 0.652 \\
\hline 1 & $\mathrm{Al}$ & $1.13 \mathrm{E}+00$ & $\mathrm{Al}(\mathrm{OH})_{3}$ & 78.003558 & 0.765 & 574.473 \\
\hline 1 & $\mathrm{Cd}$ & $1.88 \mathrm{E}-05$ & $\mathrm{Cd}\left(\mathrm{NO}_{3}\right)_{2} \cdot 4 \mathrm{H}_{2} \mathrm{O}$ & 308.48 & 0.985 & 0.030 \\
\hline 1 & $\mathrm{CO}_{3}{ }^{2-}$ & $2.74 \mathrm{E}-01$ & $\mathrm{Na}_{2} \mathrm{CO}_{3}$ & 105.98844 & 1.000 & 145.021 \\
\hline 1 & $\mathrm{Cr}$ & 2.44E-03 & $\mathrm{Na}_{2} \mathrm{Cr}_{2} \mathrm{O}_{7} \cdot 2 \mathrm{H}_{2} \mathrm{O}$ & 297.9981 & 0.990 & 3.666 \\
\hline 1 & $\mathrm{Hg}$ & 1.36E-04 & $\mathrm{Hg}\left(\mathrm{NO}_{3}\right)_{2} \cdot \mathrm{H}_{2} \mathrm{O}$ & 342.62 & 0.980 & 0.237 \\
\hline 1 & $\mathrm{PO}_{4}^{3-}$ & $8.24 \mathrm{E}-02$ & $\mathrm{Na}_{2} \mathrm{HPO}_{4} \cdot 7 \mathrm{H}_{2} \mathrm{O}$ & 267.9818 & 0.990 & 111.578 \\
\hline 1 & $\mathrm{Si}$ & $2.26 \mathrm{E}-02$ & $\mathrm{Na}_{2} \mathrm{SiO}_{3}$ & 122.06324 & 0.980 & 14.050 \\
\hline 1 & $\mathrm{SO}_{4}{ }^{2-}$ & 5.29E-02 & $\mathrm{Na}_{2} \mathrm{SO}_{4}$ & 142.0376 & 0.990 & 37.963 \\
\hline 1 & $\mathrm{NO}_{3}^{-}$ & $3.94 \mathrm{E}+00$ & $\mathrm{NaNO}_{3}$ & 84.99471 & 0.995 & 1677.857 \\
\hline 1 & $\mathrm{NO}_{2}^{-}$ & 1.44E-01 & $\mathrm{NaNO}_{2}$ & 68.99527 & 0.980 & 50.690 \\
\hline 1 & $\mathrm{Cl}^{-}$ & 2.70E-01 & $\mathrm{NaCl}$ & 58.44277 & 0.980 & 80.508 \\
\hline 1 & $\mathrm{~F}^{-}$ & 6.68E-03 & $\mathrm{NaF}$ & 40.41257 & 0.990 & 1.364 \\
\hline 3 & $\mathrm{OH}^{-}$ & $4.76 \mathrm{E}+00$ & $\mathrm{NaOH}$ & 40.01 & 0.980 & 972.488 \\
\hline 1 & $\mathrm{~K}$ & $7.00 \mathrm{E}-03$ & $\mathrm{KNO}_{3}$ & 101.1032 & 0.990 & 3.572 \\
\hline 1 & $\mathrm{~Pb}$ & $1.08 \mathrm{E}-04$ & $\mathrm{~Pb}\left(\mathrm{NO}_{3}\right)_{2}$ & 331.21 & 0.990 & 0.180 \\
\hline 1 & TOC & $1.00 \mathrm{E}+00$ & $\mathrm{Na}_{2} \mathrm{C}_{2} \mathrm{O}_{4}$ & 134 & 0.980 & 687.023 \\
\hline 1 & TOC & $1.22 \mathrm{E}-01$ & Oxalic acid dihydrate & 126.07 & 0.980 & 78.408 \\
\hline 4 & $\mathrm{I}$ & $7.88 \mathrm{E}-04$ & $\mathrm{NaI}$ & 149.89 & 0.999 & 0.591 \\
\hline 4 & $\operatorname{Re}$ & 5.37E-04 & $\mathrm{HReO}_{4}$ & - & 0.555 & 0.902 \\
\hline 2 & $\mathrm{H}_{2} \mathrm{O}$ & - & $\mathrm{H}_{2} \mathrm{O}$ & 18.01528 & 1.000 & 3239.573 \\
\hline \multicolumn{5}{|c|}{ Spiking level: $\mathrm{Re}=100 \mathrm{mg} / \mathrm{L} ; \mathrm{I}=100 \mathrm{mg} / \mathrm{L}$} & Total & 7680.890 \\
\hline
\end{tabular}


Table 2.5. Chemicals and Masses for 15 liters HSW S2 Simulant (2 M Na).

\begin{tabular}{|c|c|c|c|c|c|c|}
\hline $\begin{array}{l}\text { Order of } \\
\text { Addition }\end{array}$ & Analyte & $\begin{array}{c}\text { Target } \\
\text { Moles/L }\end{array}$ & Reagent & $\begin{array}{c}\text { Molecular } \\
\text { Weight }\end{array}$ & Assay & $\begin{array}{c}\text { Target } \\
\text { Mass (g) }\end{array}$ \\
\hline 1 & $\mathrm{Ag}$ & 1.67E-04 & $\mathrm{AgNO}_{3}$ & 169.89 & 0.999 & 0.427 \\
\hline 1 & As & $6.96 \mathrm{E}-05$ & $\mathrm{Na}_{2} \mathrm{HAsO}_{4} \cdot 7 \mathrm{H}_{2} \mathrm{O}$ & 312.01364 & 1.000 & 0.326 \\
\hline 1 & $\mathrm{Al}$ & $2.28 \mathrm{E}-01$ & $\mathrm{Al}(\mathrm{OH})_{3}$ & 78.003558 & 0.990 & 269.467 \\
\hline 1 & $\mathrm{Cd}$ & $3.14 \mathrm{E}-06$ & $\mathrm{Cd}\left(\mathrm{NO}_{3}\right)_{2} \cdot 4 \mathrm{H}_{2} \mathrm{O}$ & 308.48 & 0.985 & 0.030 \\
\hline 1 & $\mathrm{CO} 3$ & $9.32 \mathrm{E}-02$ & $\mathrm{Na}_{2} \mathrm{CO}_{3}$ & 105.98844 & 1.000 & 148.201 \\
\hline 1 & $\mathrm{Cr}$ & $4.06 \mathrm{E}-04$ & $\mathrm{Na}_{2} \mathrm{Cr}_{2} \mathrm{O}_{7} \cdot 2 \mathrm{H}_{2} \mathrm{O}$ & 297.9981 & 0.990 & 1.833 \\
\hline 1 & $\mathrm{Hg}$ & $2.26 \mathrm{E}-05$ & $\mathrm{Hg}\left(\mathrm{NO}_{3}\right)_{2} \cdot \mathrm{H}_{2} \mathrm{O}$ & 342.62 & 0.980 & 0.119 \\
\hline 1 & $\mathrm{PO}_{4}^{3-}$ & $9.70 \mathrm{E}-03$ & $\mathrm{Na}_{3} \mathrm{PO}_{4}$ & 163.94067 & 0.990 & 24.094 \\
\hline 1 & Si & $4.08 \mathrm{E}-03$ & $\mathrm{Na}_{2} \mathrm{SiO}_{3}$ & 122.06324 & 0.980 & 7.623 \\
\hline 1 & $\mathrm{SO}_{4}{ }^{2-}$ & $1.16 \mathrm{E}-02$ & $\mathrm{Na}_{2} \mathrm{SO}_{4}$ & 142.0376 & 0.999 & 24.782 \\
\hline 1 & $\mathrm{NO}_{3}^{-}$ & 3.80E-01 & $\mathrm{NaNO}_{3}$ & 84.99471 & 0.990 & 487.359 \\
\hline 1 & $\mathrm{NO}_{2}^{-}$ & $2.10 \mathrm{E}-02$ & $\mathrm{NaNO}_{2}$ & 68.99527 & 0.980 & 22.177 \\
\hline 1 & $\mathrm{Cl}^{-}$ & 4.34E-02 & $\mathrm{NaCl}$ & 58.44277 & 0.993 & 38.314 \\
\hline 1 & $\mathrm{~F}^{-}$ & $7.50 \mathrm{E}-04$ & $\mathrm{NaF}$ & 41.97921 & 0.990 & 0.477 \\
\hline 3 & $\mathrm{OH}^{-}$ & $7.96 \mathrm{E}-01$ & $\mathrm{NaOH}$ & 40.01 & 0.987 & 484.257 \\
\hline 1 & $\mathrm{~K}$ & $1.30 \mathrm{E}-03$ & $\mathrm{KNO}_{3}$ & 101.1032 & 0.990 & 1.994 \\
\hline 1 & $\mathrm{~Pb}$ & $1.80 \mathrm{E}-05$ & $\mathrm{~Pb}\left(\mathrm{NO}_{3}\right)_{2}$ & 331.21 & 0.990 & 0.090 \\
\hline 1 & TOC & $2.28 \mathrm{E}-01$ & $\mathrm{Na}_{2} \mathrm{C}_{2} \mathrm{O}_{4}$ & 134 & 0.992 & 461.976 \\
\hline 4 & $\mathrm{I}$ & 7.88E-04 & $\mathrm{NaI}$ & 149.89 & 0.990 & 1.790 \\
\hline 4 & $\mathrm{Re}$ & $7.25 \mathrm{E}-04$ & $\mathrm{HReO}_{4}$ & - & 0.562 & 3.603 \\
\hline 2 & $\mathrm{H}_{2} \mathrm{O}$ & $5.32 \mathrm{E}+01$ & $\mathrm{H}_{2} \mathrm{O}$ & 18.01528 & 1.000 & 14378.896 \\
\hline \multicolumn{5}{|c|}{ Spiking level: $\mathrm{Re}=135 \mathrm{mg} / \mathrm{L} ; \mathrm{I}=100 \mathrm{mg} / \mathrm{L}$} & Total & 16357.832 \\
\hline
\end{tabular}


Table 2.6. Chemicals and Masses for 15 liters HSW S3 Simulant (2 M Na).

\begin{tabular}{|c|c|c|c|c|c|c|}
\hline $\begin{array}{l}\text { Order of } \\
\text { Addition }\end{array}$ & Analyte & $\begin{array}{c}\text { Target } \\
\text { Moles/L }\end{array}$ & Reagent & $\begin{array}{l}\text { Molecular } \\
\text { Weight }\end{array}$ & Assay & $\begin{array}{c}\text { Target } \\
\text { Mass (g) }\end{array}$ \\
\hline 1 & Ag & $1.25 \mathrm{E}-05$ & $\mathrm{AgNO}_{3}$ & 169.89 & 0.999 & 0.032 \\
\hline 1 & As & $6.96 \mathrm{E}-05$ & $\mathrm{Na}_{2} \mathrm{HAsO}_{4} \cdot 7 \mathrm{H}_{2} \mathrm{O}$ & 312.01364 & 1.000 & 0.326 \\
\hline 1 & $\mathrm{Al}$ & $1.84 \mathrm{E}-01$ & $\mathrm{Al}(\mathrm{OH})_{3}$ & 78.003558 & 0.990 & 217.938 \\
\hline 1 & $\mathrm{Cd}$ & $3.14 \mathrm{E}-06$ & $\mathrm{Cd}\left(\mathrm{NO}_{3}\right)_{2} \cdot 4 \mathrm{H}_{2} \mathrm{O}$ & 308.48 & 0.985 & 0.015 \\
\hline 1 & $\mathrm{CO}_{3}{ }^{2-}$ & 7.88E-02 & $\mathrm{Na}_{2} \mathrm{CO}_{3}$ & 84.00661 & 1.000 & 99.316 \\
\hline 1 & $\mathrm{Cr}$ & 4.06E-04 & $\mathrm{Na}_{2} \mathrm{Cr}_{2} \mathrm{O}_{7} \cdot 2 \mathrm{H}_{2} \mathrm{O}$ & 297.9981 & 0.990 & 1.833 \\
\hline 1 & $\mathrm{Hg}$ & 2.26E-05 & $\mathrm{Hg}\left(\mathrm{NO}_{3}\right)_{2} \cdot \mathrm{H} 2 \mathrm{O}$ & 342.62 & 0.980 & 0.119 \\
\hline 1 & $\mathrm{PO}_{4}^{3-}$ & $1.21 \mathrm{E}-02$ & $\mathrm{NaH}_{2} \mathrm{PO}_{4} \cdot \mathrm{H}_{2} \mathrm{O}$ & 137.99229 & 0.990 & 25.215 \\
\hline 1 & $\mathrm{Si}$ & $1.55 \mathrm{E}-03$ & $\mathrm{Na}_{2} \mathrm{SiO}_{3}$ & 122.06324 & 0.980 & 2.892 \\
\hline 1 & $\mathrm{SO}_{4}{ }^{2-}$ & 1.03E-02 & $\mathrm{Na}_{2} \mathrm{SO}_{4}$ & 142.0376 & 0.999 & 21.924 \\
\hline 1 & $\mathrm{NO}_{3}^{-}$ & 7.94E-01 & $\mathrm{NaNO}_{3}$ & 84.99471 & 0.990 & 1016.771 \\
\hline 1 & $\mathrm{NO}_{2}^{-}$ & 7.66E-02 & $\mathrm{NaNO}_{2}$ & 68.99527 & 0.980 & 80.894 \\
\hline 1 & $\mathrm{Cl}^{-}$ & 5.82E-02 & $\mathrm{NaCl}$ & 58.44277 & 0.993 & 51.380 \\
\hline 1 & $\mathrm{~F}^{-}$ & 8.84E-04 & $\mathrm{NaF}$ & 41.97921 & 0.990 & 0.562 \\
\hline 3 & $\mathrm{OH}^{-}$ & 7.96E-01 & $\mathrm{NaOH}$ & 40.01 & 0.987 & 484.258 \\
\hline 1 & $\mathrm{~K}$ & 4.36E-03 & $\mathrm{KNO}_{3}$ & 101.1032 & 0.990 & 6.679 \\
\hline 1 & $\mathrm{~Pb}$ & $1.80 \mathrm{E}-05$ & $\mathrm{~Pb}\left(\mathrm{NO}_{3}\right)_{2}$ & 331.21 & 0.990 & 0.090 \\
\hline 1 & TOC & 8.45E-02 & $\mathrm{Na}_{2} \mathrm{C}_{2} \mathrm{O}_{4}$ & 134 & 0.992 & 171.114 \\
\hline 1 & TOC & $1.00 \mathrm{E}-01$ & Oxalic acid dihydrate & 126.07 & 0.980 & 192.868 \\
\hline 4 & $\mathrm{I}$ & 7.88E-04 & NaI & 149.89 & 0.999 & 1.7735 \\
\hline 4 & $\operatorname{Re}$ & 7.25E-04 & HReO4 & - & 0.562 & 3.6027 \\
\hline 2 & $\mathrm{H}_{2} \mathrm{O}$ & $5.21 \mathrm{E}+01$ & $\mathrm{H}_{2} \mathrm{O}$ & 18.01528 & 1.000 & 14090.722 \\
\hline \multicolumn{5}{|c|}{ Spiking level: $\mathrm{Re}=135 \mathrm{mg} / \mathrm{L} ; \mathrm{I}=100 \mathrm{mg} / \mathrm{L}$} & Total & 16470.325 \\
\hline
\end{tabular}


Table 2.7. Chemicals and Masses for 15 liters HSW S4 Simulant (2 M Na).

\begin{tabular}{|c|c|c|c|c|c|c|}
\hline $\begin{array}{l}\text { Order of } \\
\text { Addition }\end{array}$ & Analyte & $\begin{array}{l}\text { Target } \\
\text { Moles/L }\end{array}$ & Reagent & $\begin{array}{c}\text { Molecular } \\
\text { Weight }\end{array}$ & Assay & $\begin{array}{c}\text { Target } \\
\text { Mass (g) }\end{array}$ \\
\hline 1 & $\mathrm{Ag}$ & 4.70E-05 & $\mathrm{AgNO}_{3}$ & 169.89 & 0.999 & 0.120 \\
\hline 1 & As & $3.22 \mathrm{E}-05$ & $\mathrm{Na}_{2} \mathrm{HAsO}_{4} \cdot 7 \mathrm{H}_{2} \mathrm{O}$ & 312.01364 & 1.000 & 0.151 \\
\hline 1 & $\mathrm{Al}$ & $8.48 \mathrm{E}-02$ & $\mathrm{Al}(\mathrm{OH})_{3}$ & 78.003558 & 0.990 & 100.223 \\
\hline 1 & $\mathrm{NH}_{4}^{+}$ & 8.82E-01 & $\mathrm{NH}_{4} \mathrm{NO}_{3}$ & 80.04306 & 0.980 & 815.265 \\
\hline 1 & $\mathrm{Cd}$ & 4.32E-05 & $\mathrm{Cd}\left(\mathrm{NO}_{3}\right)_{2} \cdot 4 \mathrm{H}_{2} \mathrm{O}$ & 308.48 & 0.985 & 0.203 \\
\hline 1 & $\mathrm{CO}_{3}{ }^{2-}$ & $2.08 \mathrm{E}-02$ & $\left(\mathrm{NH}_{4}\right)_{2} \mathrm{CO}_{3}$ & 96.08582 & 1.000 & 29.985 \\
\hline 1 & $\mathrm{Cr}$ & $2.18 \mathrm{E}-03$ & $\mathrm{Na}_{2} \mathrm{Cr}_{2} \mathrm{O}_{7} \cdot 2 \mathrm{H}_{2} \mathrm{O}$ & 297.9981 & 0.990 & 9.843 \\
\hline 1 & $\mathrm{Hg}$ & $1.06 \mathrm{E}-05$ & $\mathrm{Hg}\left(\mathrm{NO}_{3}\right)_{2} \cdot \mathrm{H} 2 \mathrm{O}$ & 342.62 & 0.980 & 0.056 \\
\hline 1 & $\mathrm{PO}_{4}^{3-}$ & $1.02 \mathrm{E}-02$ & $\mathrm{Na}_{3} \mathrm{PO}_{4}$ & 163.94067 & 0.990 & 25.336 \\
\hline 1 & $\mathrm{Si}$ & $2.78 \mathrm{E}-02$ & $\mathrm{Na}_{2} \mathrm{SiO}_{3}$ & 122.06324 & 0.980 & 51.939 \\
\hline 1 & $\mathrm{SO}_{4}{ }^{2-}$ & 8.72E-02 & $\mathrm{Na}_{2} \mathrm{SO}_{4}$ & 132.14 & 0.990 & 174.585 \\
\hline 1 & $\mathrm{NO}_{3}^{-}$ & $2.26 \mathrm{E}+00$ & $\mathrm{NaNO}_{3}$ & 84.99471 & 0.990 & 1979.310 \\
\hline 1 & $\mathrm{NO}_{2}^{-}$ & 8.62E-02 & $\mathrm{NaNO}_{2}$ & 68.99527 & 0.980 & 91.032 \\
\hline 1 & $\mathrm{Cl}^{-}$ & 2.08E-02 & $\mathrm{NaCl}$ & 58.44277 & 0.993 & 18.363 \\
\hline 1 & $\mathrm{~K}$ & 5.74E-02 & $\mathrm{KNO}_{3}$ & 101.1032 & 0.990 & 87.929 \\
\hline 1 & $\mathrm{~Pb}$ & $1.66 \mathrm{E}-05$ & $\mathrm{~Pb}\left(\mathrm{NO}_{3}\right)_{2}$ & 331.21 & 0.990 & 0.083 \\
\hline 1 & TOC & 8.48E-02 & $\mathrm{Na}_{2} \mathrm{C}_{2} \mathrm{O}_{4}$ & 134 & 0.990 & 172.170 \\
\hline 3 & $\mathrm{I}$ & 7.88E-04 & $\mathrm{NaI}$ & 149.89 & 0.990 & 1.790 \\
\hline 3 & $\mathrm{Re}$ & 5.03E-04 & $\mathrm{NH}_{4} \mathrm{ReO}_{4}$ & 268.24306 & 0.990 & 2.044 \\
\hline 2 & $\mathrm{H}_{2} \mathrm{O}$ & $4.96 \mathrm{E}+01$ & $\mathrm{H}_{2} \mathrm{O}$ & 18.01528 & 1.000 & 13405.079 \\
\hline \multicolumn{5}{|c|}{ Spiking level: $\mathrm{Re}=93.65 \mathrm{mg} / \mathrm{L} ; \mathrm{I}=100 \mathrm{mg} / \mathrm{L}$} & Total & 16965.501 \\
\hline
\end{tabular}


Table 2.8. Chemicals and Masses for 5 liters HSW S4 Simulant (6 M Na).

\begin{tabular}{|c|c|c|c|c|c|c|}
\hline $\begin{array}{l}\text { Order of } \\
\text { Addition }\end{array}$ & Analyte & $\begin{array}{l}\text { Target } \\
\text { Moles/L }\end{array}$ & Reagent & $\begin{array}{c}\text { Molecular } \\
\text { Weight }\end{array}$ & Assay & $\begin{array}{c}\text { Target } \\
\text { Mass (g) }\end{array}$ \\
\hline 1 & $\mathrm{Ag}$ & $1.41 \mathrm{E}-04$ & $\mathrm{AgNO}_{3}$ & 169.89 & 0.999 & 0.120 \\
\hline 1 & As & 9.66E-05 & $\mathrm{Na}_{2} \mathrm{HAsO}_{4} \cdot 7 \mathrm{H}_{2} \mathrm{O}$ & 312.01364 & 1.000 & 0.151 \\
\hline 1 & $\mathrm{Al}$ & $2.54 \mathrm{E}-01$ & $\mathrm{Al}(\mathrm{OH})_{3}$ & 78.003558 & 0.765 & 129.700 \\
\hline 1 & $\mathrm{NH} 4$ & $2.65 \mathrm{E}+00$ & $\mathrm{NH}_{4} \mathrm{NO}_{3}$ & 80.04306 & 0.980 & 815.675 \\
\hline 1 & $\mathrm{Cd}$ & $1.30 \mathrm{E}-04$ & $\mathrm{Cd}\left(\mathrm{NO}_{3}\right)_{2} \cdot 4 \mathrm{H}_{2} \mathrm{O}$ & 308.48 & 0.985 & 0.203 \\
\hline 1 & $\mathrm{CO}_{3}{ }^{2-}$ & $6.24 \mathrm{E}-02$ & $\left(\mathrm{NH}_{4}\right)_{2} \mathrm{CO}_{3}$ & 96.08582 & 1.000 & 29.985 \\
\hline 1 & $\mathrm{Cr}$ & $6.54 \mathrm{E}-03$ & $\mathrm{Na}_{2} \mathrm{Cr}_{2} \mathrm{O}_{7} \cdot 2 \mathrm{H}_{2} \mathrm{O}$ & 297.9981 & 0.990 & 9.843 \\
\hline 1 & $\mathrm{Hg}$ & 3.18E-05 & $\mathrm{Hg}\left(\mathrm{NO}_{3}\right)_{2} \cdot \mathrm{H} 2 \mathrm{O}$ & 342.62 & 0.980 & 0.056 \\
\hline 1 & $\mathrm{PO}_{4}^{3-}$ & $3.06 \mathrm{E}-02$ & $\mathrm{Na}_{3} \mathrm{PO}_{4}$ & 163.94067 & 0.990 & 25.336 \\
\hline 1 & $\mathrm{Si}$ & 8.34E-02 & $\mathrm{Na}_{2} \mathrm{SiO}_{3}$ & 122.06324 & 0.980 & 51.939 \\
\hline 1 & $\mathrm{SO}_{4}{ }^{2-}$ & $2.62 \mathrm{E}-01$ & $\mathrm{Na}_{2} \mathrm{SO}_{4}$ & 132.14 & 0.990 & 174.585 \\
\hline 1 & $\mathrm{NO}_{3}^{-}$ & $6.78 \mathrm{E}+00$ & $\mathrm{NaNO}_{3}$ & 84.99471 & 0.990 & 1978.989 \\
\hline 1 & $\mathrm{NO}_{2}^{-}$ & 2.59E-01 & $\mathrm{NaNO}_{2}$ & 68.99527 & 0.980 & 91.032 \\
\hline 1 & $\mathrm{Cl}^{-}$ & $6.24 \mathrm{E}-02$ & $\mathrm{NaCl}$ & 58.44277 & 0.993 & 18.363 \\
\hline 1 & $\mathrm{~K}$ & $1.72 \mathrm{E}-01$ & $\mathrm{KNO}_{3}$ & 101.1032 & 0.990 & 87.929 \\
\hline 1 & $\mathrm{~Pb}$ & 4.97E-05 & $\mathrm{Pb}\left(\mathrm{NO}_{3}\right)_{2}$ & 331.21 & 0.990 & 0.083 \\
\hline 1 & TOC & $2.54 \mathrm{E}-01$ & $\mathrm{Na}_{2} \mathrm{C}_{2} \mathrm{O}_{4}$ & 134.00 & 0.990 & 172.170 \\
\hline 3 & $\mathrm{I}$ & 9.85E-04 & $\mathrm{NaI}$ & 149.89 & 0.990 & 0.746 \\
\hline 3 & $\mathrm{Re}$ & 6.71E-04 & $\mathrm{NH}_{4} \mathrm{ReO}_{4}$ & 268.24306 & 0.990 & 0.909 \\
\hline 2 & $\mathrm{H}_{2} \mathrm{O}$ & $4.00 \mathrm{E}+01$ & $\mathrm{H}_{2} \mathrm{O}$ & 18.01528 & 1.000 & 3276.493 \\
\hline \multicolumn{5}{|c|}{ Spiking level: $\mathrm{Re}=125 \mathrm{mg} / \mathrm{L} ; \mathrm{I}=125 \mathrm{mg} / \mathrm{L}$} & Total & 6864.305 \\
\hline
\end{tabular}


Table 3.1. Initial DuraLith Paste and Composite Binder Compositions.

\begin{tabular}{|c|c|c|c|}
\hline \multirow{2}{*}{ Constituents } & \multicolumn{2}{|c|}{ Metakaolin-based (TB6) } & \multirow{2}{*}{$\begin{array}{l}\text { Blast furnace slag-based } \\
\text { (TB9) }\end{array}$} \\
\hline & 2006 & 2009 (NT6PNL) & \\
\hline Binder & \multicolumn{3}{|c|}{$\mathrm{Wt} \%$} \\
\hline Metakaolin (MK) & 23.57 & 20.56 & 13.91 \\
\hline Blast furnace slag (BFS) & 16.13 & 14.07 & 35.52 \\
\hline Fumed silica for MK & 12.12 & 11.55 & 9.42 \\
\hline Fine river sand & - & 20.00 & - \\
\hline Fumed silica as pore filler & 2.0 & - & 1.99 \\
\hline $\mathrm{CaSO}_{4} \bullet 0.5 \mathrm{H}_{2} \mathrm{O}$ & - & - & 0.73 \\
\hline \multicolumn{4}{|l|}{ Activator } \\
\hline $\mathrm{K}_{2} \mathrm{O}$ or $\mathrm{Na}_{2} \mathrm{O}$ for $\mathrm{MK}$ & 12.18 & 10.15 & 6.94 \\
\hline \begin{tabular}{l|l} 
Waste $^{*}$ & $\mathrm{H}_{2} \mathrm{O}$ \\
\cline { 2 - 2 }
\end{tabular} & 29.0 & 21.0 & 25.78 \\
\hline Waste solids & 5.0 & 2.67 & 5.7 \\
\hline 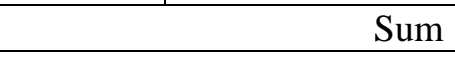 & 100.00 & 100.00 & 100.00 \\
\hline Enhancers** & $\mathrm{SnCl}_{2}, \mathrm{AgNO}_{3}$ & $\begin{array}{l}\mathrm{SnF}_{2}, \mathrm{Na}_{2} \mathrm{~S} \bullet \mathrm{xH}_{2} \mathrm{O}, \\
\text { Ag-zeolite }\end{array}$ & $\mathrm{SnCl}_{2}, \mathrm{AgNO}_{3}$ \\
\hline References & [2] & {$[3]$} & [2] \\
\hline
\end{tabular}

* Hanford secondary waste

** Total enhancers constitute about $0.7 \mathrm{wt} \%$ of the DuraLith mix 
Table 3.2. Raw Materials.

\begin{tabular}{|c|c|c|}
\hline Chemicals/Materials & Function & Source or Manufacturer \\
\hline IONEX Ag 900 & Enhancers for fixing iodide & Molecular Products \\
\hline Undensified silica fume & Silica (industrial waste) for activation solution & Cabot Corporation \\
\hline Densified silica fume & Alternative silica source (99.5\%) for activation solution & The Thiele Kaolin Company \\
\hline Metakaolin & Geopolymer binder & Advanced Cement Technologies \\
\hline Metakaolin & Geopolymer binder & Lafarge North America \\
\hline Ground blast furnace slag & Geopolymer binder & AAA Molybdenum Products \\
\hline $\mathrm{HReO}_{4}$ solution & Spiking waste simulant with rhenium & Grace Construction Products \\
\hline ADVA140M & High Range Water Reducer & Opta Minerals \\
\hline Copper slag & Geopolymer binder/enhancer for rhenium and iodide & Aggregate Industries \\
\hline River Sand & Fine aggregate & PQ Corporation \\
\hline Kasolv 16 & Alternative $\mathrm{K}_{2} \mathrm{O}$ and $\mathrm{SiO}_{2}$ sources for activation solution & Limestone Generating Station, Jewett/Texas \\
\hline Fly ash Class $\mathrm{F}$ & Geopolymer binder &
\end{tabular}


Table 3.3. Analyzed (XRF) Results of Raw Materials for DuraLith Products (wt\%).

\begin{tabular}{|c|c|c|c|c|c|c|c|c|}
\hline \multirow{2}{*}{$\begin{array}{c}\text { Chemical } \\
\text { Source }\end{array}$} & \multirow{2}{*}{$\begin{array}{c}\text { Ag-Z } \\
\text { Molecular } \\
\text { Products } \\
\end{array}$} & \multirow{2}{*}{$\frac{\text { FS }}{\text { Lafarge }}$} & \multicolumn{3}{|c|}{ MK } & \multirow{2}{*}{\begin{tabular}{|c|} 
Silica fume \\
Norchem \\
\end{tabular}} & \multirow{2}{*}{\begin{tabular}{|l|} 
Copper Slag \\
Opta Minerals \\
\end{tabular}} & \multirow{2}{*}{$\begin{array}{c}\text { Fly ash Class } \mathbf{F} \\
\text { Jewett Power } \\
\text { Station }\end{array}$} \\
\hline & & & & & $\begin{array}{c}\text { Advanced Cement } \\
\text { Technologies } \\
\end{array}$ & & & \\
\hline $\mathrm{Ag}_{2} \mathrm{O}$ & 53.60 & $<0.01$ & $<0.01$ & $<0.01$ & $<0.01$ & $<0.01$ & $<0.01$ & $<0.01$ \\
\hline $\mathrm{Al}_{2} \mathrm{O}_{3}$ & 9.62 & 9.02 & 42.78 & 42.99 & 40.04 & 0.34 & 4.48 & 20.74 \\
\hline $\mathrm{BaO}$ & $<0.01$ & 0.07 & 0.01 & $<0.01$ & 0.04 & $<0.01$ & 0.06 & 0.24 \\
\hline $\mathrm{CaO}$ & 0.92 & 36.73 & 0.03 & 0.01 & 0.04 & 0.86 & 1.87 & 11.40 \\
\hline $\mathrm{Cl}$ & $<0.01$ & 0.02 & 0.01 & $<0.01$ & $<0.01$ & 0.05 & $<0.01$ & $<0.01$ \\
\hline $\mathrm{Cr}_{2} \mathrm{O}_{3}$ & $<0.01$ & $<0.01$ & 0.03 & 0.02 & 0.02 & $<0.01$ & 0.09 & 0.02 \\
\hline $\mathrm{CuO}$ & $<0.01$ & $<0.01$ & 0.01 & 0.01 & $<0.01$ & 0.01 & 1.37 & 0.02 \\
\hline $\mathrm{Fe}_{2} \mathrm{O}_{3}$ & 1.32 & 0.35 & 0.53 & 0.42 & 2.08 & 0.73 & 53.31 & 3.89 \\
\hline $\mathrm{K} 2 \mathrm{O}$ & 0.58 & 0.38 & 0.18 & 0.19 & 0.26 & 0.73 & 1.58 & 1.47 \\
\hline $\mathrm{MgO}$ & 1.88 & 12.17 & $<0.01$ & $<0.01$ & $<0.01$ & 0.45 & 1.17 & 2.83 \\
\hline $\mathrm{MnO}$ & 0.09 & 0.50 & $<0.01$ & $<0.01$ & $<0.01$ & 0.09 & 0.07 & 0.05 \\
\hline $\mathrm{Na}_{2} \mathrm{O}$ & 0.33 & 0.27 & 0.24 & 0.27 & $<0.01$ & 0.00 & 0.42 & 0.62 \\
\hline $\mathrm{P}_{2} \mathrm{O}_{5}$ & 0.17 & $<0.01$ & 0.27 & 0.09 & 0.22 & 0.13 & 0.13 & 0.36 \\
\hline $\mathrm{PbO}$ & $<0.01$ & $<0.01$ & $<0.01$ & $<0.01$ & $<0.01$ & $<0.01$ & 0.14 & 0.01 \\
\hline $\mathrm{PdO}$ & 0.05 & $<0.01$ & $<0.01$ & $<0.01$ & $<0.01$ & $<0.01$ & $<0.01$ & $<0.01$ \\
\hline $\mathrm{Rh}_{2} \mathrm{O}_{3}$ & 0.02 & $<0.01$ & $<0.01$ & $<0.01$ & $<0.01$ & $<0.01$ & $<0.01$ & $<0.01$ \\
\hline $\mathrm{S}$ & $<0.01$ & 1.28 & $<0.01$ & $<0.01$ & $<0.01$ & $<0.01$ & 0.48 & $<0.01$ \\
\hline $\mathrm{SO}_{3}$ & $<0.01$ & $<0.01$ & 0.08 & 0.11 & 0.04 & 0.24 & $<0.01$ & 0.86 \\
\hline $\mathrm{SiO}_{2}$ & 59.76 & 38.61 & 53.74 & 54.01 & 55.49 & 93.88 & 33.13 & 56.03 \\
\hline $\mathrm{SrO}$ & $<0.01$ & 0.08 & $<0.01$ & 0.01 & 0.01 & $<0.01$ & 0.02 & 0.25 \\
\hline $\mathrm{TiO}_{2}$ & 0.17 & 0.49 & 2.07 & 1.83 & 1.70 & $<0.01$ & 0.34 & 1.13 \\
\hline $\mathrm{V}_{2} \mathrm{O}_{5}$ & $<0.01$ & $<0.01$ & 0.03 & 0.03 & 0.02 & $<0.01$ & 0.01 & 0.04 \\
\hline $\mathrm{ZnO}$ & 0.01 & $<0.01$ & $<0.01$ & $<0.01$ & 0.01 & 0.04 & 0.79 & 0.01 \\
\hline $\mathrm{ZrO} 2$ & 0.03 & 0.03 & $<0.01$ & 0.01 & 0.02 & 0.00 & 0.02 & 0.03 \\
\hline Sum & 100.00 & 100.00 & 100.00 & 100.00 & 100.00 & 97.58* & $99.48 * *$ & 100.00 \\
\hline
\end{tabular}

* 2.42 carbon; ** Containing additional $0.12 \mathrm{wt} \% \mathrm{As}_{2} \mathrm{O}_{5}, 0.08 \mathrm{wt} \% \mathrm{CoO}, 0.25 \mathrm{wt} \% \mathrm{MoO}_{3}$, and $0.07 \mathrm{wt} \% \mathrm{~Tb}_{4} \mathrm{O}_{7}$. 
Table 4.1. Constraints for Optimization of Binder and Activator Compositions.

\begin{tabular}{|c|c|c|c|}
\hline DuraLith & Constituents and Ratios & Characteristics & Optimum ratios \\
\hline \multirow{2}{*}{ Binder for waste form } & Meta-kaolin $(\mathrm{MK})$ Based & Mass ratio MK/FS=1.46 & - \\
\cline { 2 - 4 } & Furnace slag (FS) Based & Mass ratio MK/FS=0.39 & $3.55-3.88^{*}$ \\
\hline \multirow{2}{*}{$\begin{array}{c}\text { Activator for Meta- } \\
\text { kaolin (molar ratio) }\end{array}$} & $\mathrm{SiO}_{2} / \mathrm{Al}_{2} \mathrm{O}_{3}$ & $3.55-3.88$ & 1.125 \\
\cline { 2 - 4 } & $\mathrm{M}_{2} \mathrm{O} / \mathrm{Al}_{2} \mathrm{O}_{3}$ & $0.90-1.35$ & $6.0-8.0$ \\
\hline \multirow{2}{*}{$\begin{array}{c}\text { Activator for FS, } \\
\text { Copper slag (CS) and } \\
\text { FA (mass ratio) }\end{array}$} & $\mathrm{H}_{2} \mathrm{O} / \mathrm{M}_{2} \mathrm{O}^{*}$ & $4-10$ & 0.30 \\
\cline { 2 - 4 } & $\mathrm{H}_{2} \mathrm{O} /(\mathrm{FS}+\mathrm{FA}+\mathrm{CS}) *$ & 0.30 & 0.075 \\
\hline Aggregate (wt\%) & $\mathrm{SiO}_{2} /(\mathrm{FS}+\mathrm{FA}+\mathrm{CS})$ & 0.075 & 0.075 \\
\hline
\end{tabular}

$\mathrm{H}_{2} \mathrm{O}$ means the total mass of water fromall sources, including added water and water contained in a solution or in a solid, e.g., moist sand.

* Depending on waste loading

$\mathrm{FA}=$ fly ash class $\mathrm{F}$ 
Table 4.2. Compositions of DuraLith Products for Water Optimization (Waste S1) (wt\%).

\begin{tabular}{|c|c|c|c|c|c|c|c|c|c|c|c|c|c|c|c|}
\hline \multirow{2}{*}{ Sample I.D. } & \multirow{2}{*}{\begin{tabular}{|c|}
$\begin{array}{c}\text { Formulation } \\
\text { type }\end{array}$ \\
\end{tabular}} & \multirow{2}{*}{ Date } & \multirow{2}{*}{ MK } & \multirow{2}{*}{ BFS } & \multirow{2}{*}{$\begin{array}{c}\text { SF } \\
\text { filler }\end{array}$} & \multicolumn{3}{|c|}{ Activator } & \multirow{2}{*}{ Sand } & \multirow{2}{*}{$\begin{array}{l}\text { Enhancer } \\
\text { for I, Ag-Z }\end{array}$} & \multicolumn{2}{|c|}{ HSW } & \multirow{2}{*}{ Sum } & \multirow{2}{*}{ W/C } & \multirow{2}{*}{$\begin{array}{c}\text { Enhancer } \\
\text { for Re }\end{array}$} \\
\hline & & & & & & $\mathbf{K}_{2} \mathbf{O}$ & $\mathrm{Na}_{2} \mathrm{O}$ & $\mathrm{SiO}_{2}$ & & & Solids & Water & & & \\
\hline $\mathrm{S} 1-2 \mathrm{X} 2$ & $\mathrm{MK}$ & $7 / 27 / 10$ & 20.86 & 14.27 & 0.00 & 8.27 & 1.02 & 11.67 & 19.65 & 0.77 & 2.72 & 20.77 & 100.00 & 0.365 & Non \\
\hline S1-2X2A* & MK & $7 / 30 / 10$ & 20.86 & 14.27 & 0.00 & 8.27 & 1.02 & 11.67 & 19.65 & 0.77 & 2.72 & 20.77 & 100.00 & 0.365 & $\mathrm{Na}_{2} \mathrm{~S}$ \\
\hline S1-2X2B & MK & $7 / 30 / 10$ & 20.86 & 14.27 & 0.00 & 8.27 & 1.02 & 11.67 & 19.65 & 0.77 & 2.72 & 20.77 & 100.00 & 0.365 & $\mathrm{Na}_{2} \mathrm{~S}$ \\
\hline S1-2X3 & MK & $8 / 3 / 10$ & 21.10 & 14.44 & 0.00 & 8.32 & 1.03 & 11.80 & 19.66 & 0.77 & 2.64 & 20.25 & 100.00 & 0.352 & $\mathrm{Na}_{2} \mathrm{~S}$ \\
\hline $\mathrm{S} 1-2 \mathrm{X} 4$ & MK & $8 / 3 / 10$ & 25.71 & 17.59 & 2.01 & 11.79 & 1.41 & 14.36 & 0.00 & 0.75 & 2.86 & 23.52 & 100.00 & 0.319 & $\mathrm{Na}_{2} \mathrm{~S}$ \\
\hline S1-2X5 & FS & $8 / 5 / 10$ & 14.52 & 37.48 & 1.99 & 7.42 & 2.91 & 10.21 & 0.00 & 0.99 & 2.72 & 21.77 & 100.00 & 0.288 & $\mathrm{SnF}_{2}$ \\
\hline S1-2X6 & MK & $8 / 5 / 10$ & 25.94 & 17.75 & 2.01 & 12.01 & 1.43 & 14.38 & 0.00 & 1.00 & 2.75 & 22.74 & 100.00 & 0.305 & $\mathrm{SnF}_{2}$ \\
\hline $\mathrm{S} 1-2 \mathrm{X} 8$ & FS & $8 / 11 / 10$ & 11.52 & 29.72 & 1.98 & 6.23 & 2.33 & 8.12 & 18.80 & 0.99 & 2.24 & 18.06 & 100.00 & 0.296 & $\mathrm{SnF}_{2}$ \\
\hline $\mathrm{S} 1-2 \mathrm{X} 9$ & MK & $8 / 11 / 10$ & 20.17 & 13.80 & 2.00 & 9.67 & 1.14 & 11.36 & 18.96 & 1.00 & 2.37 & 19.54 & 100.00 & 0.330 & $\mathrm{SnF}_{2}$ \\
\hline S1-2X10R & FS & $8 / 20 / 10$ & 11.91 & 30.73 & 2.02 & 4.55 & 2.41 & 8.35 & 19.20 & 1.01 & 2.28 & 17.54 & 100.00 & 0.288 & $\mathrm{SnF}_{2}$ \\
\hline S1-2X11R & MK & $8 / 20 / 10$ & 20.66 & 14.14 & 2.00 & 9.73 & 1.17 & 11.52 & 19.00 & 1.00 & 2.23 & 18.55 & 100.00 & 0.308 & $\mathrm{SnF}_{2}$ \\
\hline $\mathrm{S} 1-2 \mathrm{X} 12$ & FS & $8 / 25 / 10$ & 11.84 & 30.55 & 2.00 & 5.59 & 2.40 & 8.29 & 19.00 & 1.00 & 2.17 & 17.15 & 100.00 & 0.278 & $\mathrm{Na}_{2} \mathrm{~S}$ \\
\hline S1-2X13 & MK & $8 / 25 / 10$ & 20.74 & 14.19 & 2.00 & 9.78 & 1.17 & 11.56 & 19.00 & 1.00 & 2.20 & 18.35 & 100.00 & 0.304 & $\mathrm{Na}_{2} \mathrm{~S}$ \\
\hline $\mathrm{S} 1-2 \mathrm{X} 14^{* *}$ & FS & $8 / 31 / 10$ & 12.18 & 31.44 & 1.01 & 4.67 & 2.39 & 8.49 & 19.21 & 1.01 & 2.16 & 17.44 & 100.00 & 0.285 & $\mathrm{SnF}_{2}$ \\
\hline $\mathrm{S} 1-2 \mathrm{X} 15^{* *}$ & MK & $8 / 31 / 10$ & 21.17 & 14.49 & 1.00 & 9.99 & 1.12 & 11.79 & 19.00 & 1.00 & 2.09 & 18.35 & 100.00 & 0.303 & $\mathrm{SnF}_{2}$ \\
\hline S1-2X16 & FS & $9 / 8 / 10$ & 14.98 & 38.65 & 1.00 & 7.32 & 2.92 & 10.50 & 0.00 & 1.00 & 2.64 & 21.00 & 100.00 & 0.275 & $\mathrm{SnF}_{2}$ \\
\hline S1-2X17 & MK & $9 / 8 / 10$ & 26.38 & 18.05 & 1.00 & 12.89 & 1.38 & 14.72 & 0.00 & 1.00 & 2.58 & 22.00 & 100.00 & 0.292 & $\mathrm{SnF}_{2}$ \\
\hline S1-2X20 & FS & $9 / 8 / 10$ & 11.83 & 30.52 & 2.00 & 6.05 & 2.40 & 5.61 & 19.00 & 1.00 & 2.15 & 17.15 & 100.00 & 0.278 & $\mathrm{SnF}_{2} / \mathrm{Na}_{2} \mathrm{~S}$ \\
\hline S1-2X21 & MK & $9 / 8 / 10$ & 20.66 & 14.14 & 2.00 & 10.55 & 1.17 & 9.79 & 19.00 & 1.00 & 2.18 & 18.45 & 100.00 & 0.306 & $\mathrm{SnF}_{2} / \mathrm{Na}_{2} \mathrm{~S}$ \\
\hline
\end{tabular}

* Used Cabot silica fume 99.9\% purity.

** These samples were made with simulant in which aluminum was added in the form of sodium aluminate, instead of aluminum hydroxide 
Table 4.3. Composition of DuraLith Products for Waste Simulants S2, S3, S4 (all 2 M Na) (wt\%).

\begin{tabular}{|c|c|c|c|c|c|c|c|c|c|c|c|c|c|c|}
\hline \multirow{2}{*}{ Sample } & \multirow{2}{*}{$\begin{array}{c}\text { Formulation } \\
\text { Type }\end{array}$} & \multirow{2}{*}{ Date } & \multirow{2}{*}{ MK } & \multirow{2}{*}{ BFS } & \multirow{2}{*}{$\begin{array}{c}\text { SF } \\
\text { filler }\end{array}$} & \multicolumn{3}{|c|}{ Activator } & \multirow{2}{*}{ Sand } & \multirow{2}{*}{$\begin{array}{c}\text { Enhancer } \\
\text { for I, Ag-Z }\end{array}$} & \multicolumn{2}{|c|}{ HSW } & \multirow{2}{*}{ Sum } & \multirow{2}{*}{$\mathbf{W} / \mathrm{C}$} \\
\hline & & & & & & $\mathrm{K}_{2} \mathrm{O}$ & $\mathrm{Na}_{2} \mathrm{O}$ & $\mathrm{SiO}_{2}$ & & & Solids & Water & & \\
\hline $\mathrm{S} 2-2 \mathrm{X} 1$ & MK & 8/19/10 & 20.80 & 14.23 & 2.00 & 9.81 & 1.17 & 11.63 & 19.00 & \begin{tabular}{|l|}
1.00 \\
\end{tabular} & 2.02 & 18.35 & 100.00 & 0.303 \\
\hline $\mathrm{S} 2-2 \mathrm{X} 4$ & FS & 8/19/10 & 11.83 & 30.52 & 2.00 & 5.60 & 2.39 & 8.29 & 19.00 & 1.00 & 2.02 & 17.35 & 100.00 & 0.282 \\
\hline S2-2X1R & MK & $9 / 17 / 10$ & 21.08 & 14.43 & 1.00 & 10.30 & 1.11 & 11.73 & 19.00 & 1.00 & 2.00 & 18.35 & 100.00 & 0.303 \\
\hline S2-2X4R & FS & $9 / 17 / 10$ & 12.10 & 31.23 & 1.00 & 5.92 & 2.37 & 8.47 & 19.00 & 1.00 & 1.95 & 16.95 & 100.00 & 0.273 \\
\hline S3-2X1R & MK & $8 / 20 / 10$ & 20.60 & 14.10 & 2.00 & 9.74 & 1.16 & 11.49 & 19.00 & 1.00 & 2.46 & 18.45 & 100.00 & 0.307 \\
\hline S3-2X2R & FS & $8 / 20 / 10$ & 11.74 & 30.30 & 2.00 & 5.55 & 2.38 & 8.23 & 19.00 & 1.00 & 2.44 & 17.35 & 100.00 & 0.283 \\
\hline $\mathrm{S} 4-2 \mathrm{X} 1$ & MK & $8 / 19 / 10$ & 20.15 & 13.79 & 2.00 & 9.50 & 1.18 & 11.25 & 19.00 & 1.00 & 3.88 & 18.25 & 100.00 & 0.310 \\
\hline S4-2X1R & MK & $9 / 17 / 10$ & 20.05 & 13.72 & 2.00 & 9.79 & 1.18 & 11.16 & 19.00 & 1.00 & 3.85 & 18.25 & 100.00 & 0.310 \\
\hline S4-2X4 & FS & 8/19/10 & 11.49 & 29.66 & 2.00 & 5.43 & 2.37 & 8.05 & 19.00 & 1.00 & 3.84 & 17.15 & 100.00 & 0.286 \\
\hline
\end{tabular}


Table 4.4. Properties of DuraLith Pastes and Products for Waste S1 (Water Optimization).

\begin{tabular}{|c|c|c|c|c|c|c|c|c|c|}
\hline Sample I.D. & \begin{tabular}{|c|}
$\begin{array}{c}\text { Formulation } \\
\text { type }\end{array}$ \\
\end{tabular} & Date & $\mathbf{W} / \mathbf{C}$ & $\begin{array}{c}\text { Paste } \\
\text { characteristics }\end{array}$ & \begin{tabular}{|c|}
$\begin{array}{c}\text { Open lid during } \\
\text { Curing }\end{array}$ \\
\end{tabular} & Bleeding & $\begin{array}{l}\text { Time to } \\
\text { harden }\end{array}$ & $\begin{array}{c}\text { Surface } \\
\text { cracking }\end{array}$ & $\begin{array}{c}28 \text { day Compressive } \\
\text { strength (psi) }\end{array}$ \\
\hline $\mathrm{S} 1-2 \mathrm{X} 2$ & MK & $7 / 27 / 10$ & 0.365 & Very easily pourable & Yes & No & $>120 \mathrm{~min}$ & Yes & 12445 \\
\hline S1-2X2A & MK & 7/30/10 & 0.365 & Very easily pourable & Yes & No & 135 min & Yes & 13132 \\
\hline S1-2X2B & MK & $7 / 30 / 10$ & 0.365 & Very easily pourable & Yes & No & $150 \mathrm{~min}$ & Yes & 11762 \\
\hline S1-2X3 & MK & $8 / 3 / 10$ & 0.352 & Very easily pourable & Yes & No & $120 \mathrm{~min}$ & Yes & 12999 \\
\hline $\mathrm{S} 1-2 \mathrm{X} 4$ & MK & $8 / 3 / 10$ & 0.319 & Easily pourable & Yes & No & $100 \mathrm{~min}$ & Yes & ND \\
\hline $\mathrm{S} 1-2 \mathrm{X} 5$ & FS & $8 / 5 / 10$ & 0.288 & Easily pourable & Yes & No & $162 \min$ & Yes & 13537 \\
\hline $\mathrm{S} 1-2 \mathrm{X} 6$ & MK & $8 / 5 / 10$ & 0.305 & Easily pourable & Yes & No & $>95$ min & Yes & ND \\
\hline $\mathrm{S} 1-2 \mathrm{X} 8$ & FS & $8 / 11 / 10$ & 0.296 & Easily pourable & Yes & No & $125 \mathrm{~min}$ & No & 20196 \\
\hline S1-2X9 & MK & $8 / 11 / 10$ & 0.330 & Easily pourable & Yes & No & $130 \mathrm{~min}$ & Yes & 11645 \\
\hline S1-2X10R & FS & 8/20/10 & 0.288 & Easily pourable & Lid/6mm hole & No & $131 \mathrm{~min}$ & No & 20566 \\
\hline S1-2X11R & MK & $8 / 20 / 10$ & 0.308 & Easily pourable & Lid/6mm hole & No & $>135$ min & No & 12982 \\
\hline S1-2X12 & FS & $8 / 25 / 10$ & 0.278 & Easily pourable & Lid/6mm hole & No & $>129$ min & No & 17118 \\
\hline S1-2X13 & MK & $8 / 25 / 10$ & 0.304 & Pours slowly & Lid/6mm hole & No & $>85$ min & No & 10601 \\
\hline S1-2X14 & FS & 8/31/10 & 0.285 & Easily pourable & Lid/6mm hole & No & 155 min & No & 23728 \\
\hline S1-2X15 & MK & $8 / 31 / 10$ & 0.303 & Pours slowly & Lid/6mm hole & No & $>94 \mathrm{~min}$ & No & 11896 \\
\hline S1-2X16 & FS & $9 / 8 / 10$ & 0.275 & Pours slowly & Lid/6mm hole & No & 130 min & No & 16199 \\
\hline S1-2X17 & MK & $9 / 8 / 10$ & 0.292 & Pours slowly & Lid/6mm hole & No & $110 \mathrm{~min}$ & No & 6922 \\
\hline S1-2X20 & FS & $9 / 8 / 10$ & 0.278 & Pours slowly & Lid/6mm hole & No & $74 \mathrm{~min}$ & No & 19846 \\
\hline $\mathrm{S} 1-2 \mathrm{X} 21$ & MK & $9 / 8 / 10$ & 0.306 & Pours slowly & Lid/6mm hole & No & 155 min & No & 12173 \\
\hline
\end{tabular}

ND - Not determined 
Table 4.5. Properties of DuraLith Pastes and Products for Wastes S2, S3, and S4.

\begin{tabular}{|c|c|c|c|c|c|c|c|c|}
\hline Sample I.D. & \begin{tabular}{|c|}
$\begin{array}{c}\text { Formulation } \\
\text { type }\end{array}$ \\
\end{tabular} & Date & $\mathrm{W} / \mathrm{C}$ & $\begin{array}{c}\text { Paste } \\
\text { characteristics }\end{array}$ & Bleeding & $\begin{array}{l}\text { Time to } \\
\text { harden }\end{array}$ & $\begin{array}{l}\text { Surface } \\
\text { cracking }\end{array}$ & $\begin{array}{c}28 \text { day Compressive } \\
\text { strength (psi) }\end{array}$ \\
\hline $\mathrm{S} 2-2 \mathrm{X} 1$ & MK & $8 / 19 / 10$ & 0.303 & Pours slowly & No & $145 \mathrm{~min}$ & No & 10093 \\
\hline $\mathrm{S} 2-2 \mathrm{X} 4$ & FS & $8 / 19 / 10$ & 0.282 & Pours slowly & No & $140 \mathrm{~min}$ & No & 19538 \\
\hline $\mathrm{S} 2-2 \mathrm{X} 1 \mathrm{R}$ & MK & $9 / 17 / 10$ & 0.303 & Pours slowly & No & $>107$ min & No & 11973 \\
\hline S2-2X4R & FS & $9 / 17 / 10$ & 0.273 & Easily pourable & No & $134 \mathrm{~min}$ & No & 25823 \\
\hline S3-2X1R & MK & $8 / 20 / 10$ & 0.307 & Pours slowly & No & 141 min & No & 12917 \\
\hline S3-2X2R & FS & $8 / 20 / 10$ & 0.283 & Pours slowly & No & $139 \mathrm{~min}$ & No & 19856 \\
\hline S4-2X1 & MK & $8 / 19 / 10$ & 0.310 & Easily pourable & $<0.7$ vol. $\%$ & $105 \min$ & No & $\sim 10000$ \\
\hline S4-2X1R & MK & $9 / 17 / 10$ & 0.310 & Pours slowly & No & 155 min & No & 12034 \\
\hline $\mathrm{S} 4-2 \mathrm{X} 4$ & FS & $8 / 19 / 10$ & 0.286 & Easily pourable & $<0.5$ vol. $\%$ & $125 \mathrm{~min}$ & No & 16008 \\
\hline
\end{tabular}


Table 4.6. Composition of DuraLith Products with Combinations of Enhancers and Other Additives (Waste S1) (wt\%).

\begin{tabular}{|c|c|c|c|c|c|c|c|c|c|c|c|c|c|c|c|c|}
\hline \multirow{2}{*}{ Sample } & \multirow{2}{*}{\begin{tabular}{|c|}
$\begin{array}{c}\text { Formulation } \\
\text { Type }\end{array}$ \\
\end{tabular}} & \multirow{2}{*}{ Date } & \multirow{2}{*}{ MK } & \multirow{2}{*}{ BFS } & \multirow{2}{*}{$\begin{array}{c}\text { SF } \\
\text { filler }\end{array}$} & \multicolumn{2}{|c|}{ Activa } & \multirow[b]{2}{*}{$\mathrm{SiO}_{2}$} & \multirow{2}{*}{ Sand } & \multirow{2}{*}{$\begin{array}{c}\text { Enhancer } \\
\text { for I* }\end{array}$} & \multirow{2}{*}{\begin{tabular}{|c|} 
Other \\
Additives \\
\end{tabular}} & \multicolumn{2}{|c|}{ HSW } & \multirow{2}{*}{ Sum } & \multirow{2}{*}{ W/C } & \multirow{2}{*}{$\begin{array}{c}\text { Enhancer } \\
\text { for } R e\end{array}$} \\
\hline & & & & & & $\mathrm{K}_{2} \mathrm{O}$ & $\mathrm{Na}_{2} \mathrm{O}$ & & & & & Solids & Water & & & \\
\hline S1-2X12R1 & FS & $9 / 1 / 10$ & 11.79 & 30.41 & 2.00 & 5.81 & 2.39 & 8.28 & 19.00 & 1.00 & 0.00 & 2.17 & 17.15 & 100.00 & 0.278 & $\mathrm{Na}_{2} \mathrm{~S}$ \\
\hline S1-2X12R2 & FS & $9 / 1 / 10$ & 11.79 & 30.41 & 2.00 & 5.81 & 2.39 & 8.28 & 19.00 & 1.00 & 0.00 & 2.17 & 17.15 & 100.00 & 0.278 & $\mathrm{SnF}_{2}$ \\
\hline S1-2X13R1 & MK & $9 / 1 / 10$ & 20.57 & 14.07 & 2.00 & 10.11 & 1.16 & 11.54 & 19.00 & 1.00 & 0.00 & 2.20 & 18.35 & 100.00 & 0.304 & $\mathrm{Na}_{2} \mathrm{~S}$ \\
\hline S1-2X13R2 & MK & $9 / 1 / 10$ & 20.57 & 14.07 & 2.00 & 10.11 & 1.16 & 11.54 & 19.00 & 1.00 & 0.00 & 2.20 & 18.35 & 100.00 & 0.304 & $\mathrm{SnF}_{2}$ \\
\hline S1-4X1R2 & MK & $9 / 28 / 10$ & 21.17 & 14.49 & 1.02 & - & 1.08 & - & 19.33 & 1.02 & $20.60^{1)}$ & 3.23 & 18.06 & 100.00 & 0.304 & $\mathrm{SnF}_{2}$ \\
\hline S1-2X22 & FS & $9 / 14 / 10$ & 11.88 & 25.66 & 2.00 & 5.60 & 2.41 & 8.30 & 19.00 & 1.00 & $5.00^{2)}$ & 2.15 & 17.00 & 100.00 & 0.275 & $\mathrm{SnF}_{2}$ \\
\hline S1-2X23 & MK & $9 / 14 / 10$ & 20.35 & 13.92 & 2.00 & 9.60 & 1.53 & 11.71 & 14.00 & 1.00 & $5.00^{2)}$ & 2.24 & 18.65 & 100.00 & 0.286 & $\mathrm{SnF}_{2}$ \\
\hline S1-2X18 & FS & $9 / 21 / 10$ & 12.01 & 30.99 & 1.00 & 5.69 & 2.76 & 8.79 & 11.00 & 0.00 & $8.00^{3)}$ & 2.21 & 17.55 & 100.00 & 0.253 & $\mathrm{SnF}_{2}$ \\
\hline S1-2X19 & MK & $9 / 21 / 10$ & 21.02 & 14.38 & 1.00 & 9.95 & 1.51 & 12.15 & 11.00 & 0.00 & $8.00^{3)}$ & 2.24 & 18.75 & 100.00 & 0.276 & $\mathrm{SnF}_{2}$ \\
\hline
\end{tabular}

1) Kasolv 16, a soluble potassium silicate glassy powders from PQ Corporation

2) Fly ash Class $F$

3) Ground copper slag

* Ag-Z (IONEX Ag 900) 
Table 4.7. Properties of DuraLith Pastes and Products with Combinations of Enhancers and Other Additives (S1).

\begin{tabular}{|c|c|c|c|c|c|c|c|c|c|}
\hline Sample I.D. & $\begin{array}{c}\text { Formulation } \\
\text { Type }\end{array}$ & Date & $\mathbf{W} / \mathbf{C}$ & $\begin{array}{c}\text { Paste } \\
\text { characteristics }\end{array}$ & Bleeding & $\begin{array}{l}\text { Time to } \\
\text { harden }\end{array}$ & $\begin{array}{l}\text { Surface } \\
\text { cracking }\end{array}$ & $\begin{array}{l}28 \text { day Compressive } \\
\text { strength (psi) }\end{array}$ & Other Additives \\
\hline S1-2X12R1 & FS & $9 / 1 / 10$ & 0.278 & Pours slowly & No & $70 \mathrm{~min}$ & No & 14960 & Non \\
\hline S1-2X12R2 & FS & $9 / 1 / 10$ & 0.278 & Pours slowly & No & $>75 \min$ & No & 17036 & Non \\
\hline S1-2X13R1 & MK & $9 / 1 / 10$ & 0.304 & Pours slowly & No & $>67 \min$ & No & 11720 & Non \\
\hline S1-2X13R2 & MK & $9 / 1 / 10$ & 0.304 & Pours slowly & $<0.2$ vol.\% & $>55 \mathrm{~min}$ & No & 11341 & Non \\
\hline S1-4X1R2 & MK & $9 / 28 / 10$ & 0.304 & Easily pourable & No & $152 \min$ & No & 13210 & Kasolv 16 \\
\hline S1-2X22 & FS & $9 / 14 / 10$ & 0.275 & Easily pourable & No & $\sim 121$ min & No & 19085 & Fly ash Class F \\
\hline S1-2X23 & MK & 9/14/10 & 0.286 & Pours slowly & No & $>105 \min$ & No & 11008 & Fly ash Class F \\
\hline S1-2X18 & FS & $9 / 21 / 10$ & 0.253 & Easily pourable & No & $>130 \mathrm{~min}$ & No & 20024 & Copper slag \\
\hline S1-2X19 & $\mathrm{MK}$ & $9 / 21 / 10$ & 0.276 & Pours slowly & No & $\sim 155$ min & No & 12190 & Copper slag \\
\hline
\end{tabular}


Table 4.8. DuraLith Composition Variations (Robustness Tests) (wt\%).*

\begin{tabular}{|c|c|c|c|c|c|c|c|c|c|c|c|c|c|c|c|}
\hline \multirow{2}{*}{ Sample I.D. } & \multirow{2}{*}{ Variation } & \multirow{2}{*}{ Date } & \multirow{2}{*}{ MK } & \multirow{2}{*}{ BFS } & \multirow{2}{*}{$\begin{array}{c}\text { SF } \\
\text { filler }\end{array}$} & \multicolumn{3}{|c|}{ Activator } & \multirow{2}{*}{ Sand } & \multirow{2}{*}{\begin{tabular}{|c|} 
Enhancer for \\
I, Ag-Z
\end{tabular}} & \multirow{2}{*}{$\begin{array}{l}\text { Copper } \\
\text { Slag }\end{array}$} & \multicolumn{2}{|c|}{ HSW } & \multirow{2}{*}{ Sum } & \multirow{2}{*}{ W/C } \\
\hline & & & & & & $\mathbf{K}_{2} \mathbf{O}$ & $\mathrm{Na}_{2} \mathrm{O}$ & $\mathrm{SiO}_{2}$ & & & & Solids & Water & & \\
\hline S1-2XV0 & Baseline & $10 / 8 / 10$ & 12.03 & 31.04 & 1.00 & 5.74 & 2.46 & 8.45 & 17.00 & 1.00 & 2.00 & 2.13 & 17.15 & 100.00 & 0.278 \\
\hline S1-2XV1 & Baseline & $10 / 8 / 10$ & 12.03 & 31.04 & 1.00 & 5.74 & 2.46 & 8.45 & 17.00 & 1.00 & 2.00 & 2.13 & 17.15 & 100.00 & 0.278 \\
\hline S1-2XV1R & $-10 \% \mathrm{MK}$ & $10 / 22 / 10$ & 10.96 & 31.41 & 1.01 & 5.81 & 2.49 & 8.55 & 17.21 & 1.01 & 2.02 & 2.16 & 17.36 & 100.00 & 0.283 \\
\hline S1-2XV2 & $-10 \% \mathrm{FS}$ & $10 / 8 / 10$ & 12.41 & 28.83 & 1.03 & 5.93 & 2.54 & 8.72 & 17.54 & 1.03 & 2.06 & 2.20 & 17.70 & 100.00 & 0.293 \\
\hline S1-2XV3 & $-10 \% \mathrm{SF}$ & $10 / 8 / 10$ & 12.10 & 31.22 & 1.01 & 5.78 & 2.48 & 7.89 & 17.10 & 1.01 & 2.01 & 2.15 & 17.25 & 100.00 & 0.281 \\
\hline S1-2XV4 & $-10 \% \mathrm{KOH}$ & $10 / 8 / 10$ & 12.10 & 31.22 & 1.01 & 5.20 & 2.48 & 8.50 & 17.10 & 1.01 & 2.01 & 2.15 & 17.25 & 100.00 & 0.280 \\
\hline S1-2XV5 & $+10 \% \mathrm{MK}$ & $10 / 14 / 10$ & 13.07 & 30.67 & 0.99 & 5.67 & 2.43 & 8.35 & 16.80 & 0.99 & 1.98 & 2.11 & 16.95 & 100.00 & 0.273 \\
\hline S1-2XV6 & $+10 \% \mathrm{FS}$ & $10 / 14 / 10$ & 11.67 & 33.11 & 0.97 & 5.57 & 2.39 & 8.19 & 16.49 & 0.97 & 1.94 & 2.07 & 16.63 & 100.00 & 0.265 \\
\hline S1-2XV7 & $+10 \% \mathrm{SF}$ & $10 / 14 / 10$ & 11.96 & 30.85 & 0.99 & 5.71 & 2.45 & 9.00 & 16.90 & 0.99 & 1.99 & 2.12 & 17.05 & 100.00 & 0.275 \\
\hline S1-2XV8 & $+10 \% \mathrm{KOH}$ & $10 / 14 / 10$ & 11.96 & 30.86 & 0.99 & 6.28 & 2.45 & 8.40 & 16.90 & 0.99 & 1.99 & 2.12 & 17.05 & 100.00 & 0.275 \\
\hline
\end{tabular}

* $15 \mathrm{~g} \mathrm{SnF}_{2}$ was added to each batch as an enhancer to fix Tc during mixing dry ingredients with liquids. 
Table 4.9. Properties of DuraLith Pastes and Products (Robustness Tests).

\begin{tabular}{|c|c|c|c|c|c|c|c|c|}
\hline Sample I.D. & Variation & Date & $\mathrm{W} / \mathrm{C}$ & $\begin{array}{c}\text { Paste } \\
\text { characteristics }\end{array}$ & Bleeding & $\begin{array}{l}\text { Time to } \\
\text { harden }\end{array}$ & $\begin{array}{c}\text { Surface } \\
\text { cracking }\end{array}$ & $\begin{array}{c}28 \text { day Compressive } \\
\text { strength (psi) }\end{array}$ \\
\hline S1-2XV0 & Baseline & $10 / 8 / 10$ & 0.278 & Pours slowly & No & $145 \min$ & No & 20865 \\
\hline S1-2XV1 & Baseline & $10 / 8 / 10$ & 0.278 & Easily pourable & No & $90 \mathrm{~min}$ & No & 22667 \\
\hline S1-2XV1R & $-10 \% \mathrm{MK}$ & $10 / 22 / 10$ & 0.283 & Easily pourable & No & $>160 \min$ & No & 18983 \\
\hline S1-2XV2 & $-10 \% \mathrm{FS}$ & $10 / 8 / 10$ & 0.293 & Easily pourable & No & $>95 \min$ & No & 22439 \\
\hline S1-2XV3 & $-10 \% \mathrm{SF}$ & $10 / 8 / 10$ & 0.281 & Easily pourable & No & $140 \mathrm{~min}$ & No & 20608 \\
\hline S1-2XV4 & $-10 \% \mathrm{KOH}$ & $10 / 8 / 10$ & 0.280 & Pours slowly & No & $145 \mathrm{~min}$ & No & 19738 \\
\hline S1-2XV5 & $+10 \% \mathrm{MK}$ & $10 / 14 / 10$ & 0.273 & Pours slowly & No & $85 \mathrm{~min}$ & No & 20755 \\
\hline S1-2XV6 & $+10 \% \mathrm{FS}$ & $10 / 14 / 10$ & 0.265 & Pours slowly & No & $133 \mathrm{~min}$ & No & 21380 \\
\hline S1-2XV7 & $+10 \% \mathrm{SF}$ & $10 / 14 / 10$ & 0.275 & Pours slowly & No & 125 min & No & 16757 \\
\hline S1-2XV8 & $+10 \% \mathrm{KOH}$ & $10 / 14 / 10$ & 0.275 & Pours slowly & No & 98 min & No & 19420 \\
\hline
\end{tabular}


Table 4.10. Compositions of DuraLith Products with Higher Waste Loading (S1) (wt\%).

\begin{tabular}{|c|c|c|c|c|c|c|c|c|c|c|c|c|c|c|c|c|}
\hline \multirow{2}{*}{ Sample I.D. } & \multirow{2}{*}{\begin{tabular}{|c|}
$\begin{array}{c}\text { Formul. } \\
\text { type }\end{array}$ \\
\end{tabular}} & \multirow{2}{*}{ Waste } & \multirow{2}{*}{ Date } & \multirow{2}{*}{ MK } & \multirow{2}{*}{ BFS } & \multirow{2}{*}{$\begin{array}{c}\text { SF } \\
\text { filler }\end{array}$} & \multicolumn{3}{|c|}{ Activator } & \multirow{2}{*}{ Sand } & \multirow{2}{*}{$\begin{array}{c}\text { Enhancer } \\
\text { for I (Ag-Z) }\end{array}$} & \multirow{2}{*}{$\begin{array}{c}\text { Copper } \\
\text { slag }\end{array}$} & \multicolumn{2}{|c|}{ HSW } & \multirow{2}{*}{ Sum } & \multirow{2}{*}{$\mathbf{W} / \mathbf{C}$} \\
\hline & & & & & & & $\mathbf{K}_{2} \mathbf{O}$ & $\mathrm{Na}_{2} \mathrm{O}$ & $\mathrm{SiO}_{2}$ & & & & Solids & Water & & \\
\hline S1-8X1 & MK & $8 \mathrm{M} \mathrm{Na}$ & $9 / 21 / 10$ & 18.87 & 12.91 & 1.02 & 7.48 & 0.84 & 10.53 & 19.33 & 1.02 & 0.00 & 10.70 & 17.30 & 100.00 & 0.328 \\
\hline S1-8X2 & FS & $8 \mathrm{M} \mathrm{Na}$ & $9 / 21 / 10$ & 10.76 & 27.75 & 1.01 & 4.25 & 1.96 & 7.51 & 19.19 & 1.01 & 0.00 & 10.41 & 16.16 & 100.00 & 0.298 \\
\hline S1-8X1R ${ }^{1)}$ & MK & $8 \mathrm{M} \mathrm{Na}$ & $9 / 29 / 10$ & 19.84 & 13.58 & 1.02 & 7.67 & 0.90 & 10.43 & 19.34 & 1.02 & 0.00 & 9.90 & 16.29 & 100.00 & 0.299 \\
\hline S1-8X2R ${ }^{1)}$ & FS & $8 \mathrm{M} \mathrm{Na}$ & 9/29/10 & 11.28 & 29.12 & 1.01 & 4.36 & 2.08 & 7.54 & 19.19 & 1.01 & 0.00 & 9.45 & 14.95 & 100.00 & 0.265 \\
\hline $\mathrm{S} 1-5 \mathrm{X} 1^{1)}$ & FS & $5 \mathrm{M} \mathrm{Na}$ & $10 / 1 / 10$ & 11.87 & 30.63 & 1.03 & 4.59 & 2.23 & 7.94 & 19.57 & 1.03 & 0.00 & 5.42 & 15.71 & 100.00 & 0.265 \\
\hline $\mathrm{S} 1-5 \mathrm{X} 2^{1)}$ & MK & $5 \mathrm{M} \mathrm{Na}$ & $10 / 1 / 10$ & 21.08 & 14.42 & 1.04 & 8.14 & 1.01 & 11.07 & 19.74 & 1.04 & 0.00 & 5.58 & 16.88 & 100.00 & 0.292 \\
\hline S1-6X1R ${ }^{1)}$ & FS & $6 \mathrm{M} \mathrm{Na}$ & $10 / 6 / 10$ & 11.47 & 29.60 & 1.01 & 4.44 & 2.15 & 7.97 & 19.20 & 1.01 & 0.00 & 7.39 & 15.76 & 100.00 & 0.273 \\
\hline S1-6X2R ${ }^{1)}$ & MK & $6 \mathrm{M} \mathrm{Na}$ & $10 / 6 / 10$ & 20.25 & 13.86 & 1.02 & 7.83 & 0.97 & 11.20 & 19.35 & 1.02 & 0.00 & 7.60 & 16.90 & 100.00 & 0.301 \\
\hline S1-4X1R3 & MK & $4 \mathrm{M} \mathrm{Na}$ & $10 / 6 / 10$ & 20.82 & 14.25 & 1.02 & 8.05 & 1.05 & 11.52 & 19.36 & 1.02 & 0.00 & 4.82 & 18.09 & 100.00 & 0.313 \\
\hline S1-4X2R1 & FS & $4 \mathrm{M} \mathrm{Na}$ & $10 / 6 / 10$ & 11.70 & 30.20 & 1.01 & 4.53 & 2.25 & 8.14 & 19.20 & 1.01 & 0.00 & 4.78 & 17.18 & 100.00 & 0.292 \\
\hline S1-6X1R1 ${ }^{1,2)}$ & FS & $6 \mathrm{M} \mathrm{Na}$ & $11 / 3 / 10$ & 11.24 & 29.01 & 0.99 & 4.35 & 2.11 & 7.82 & 18.82 & 0.99 & 1.98 & 7.25 & 15.45 & 100.00 & 0.273 \\
\hline $\mathrm{S} 1-6 \mathrm{X} 2 \mathrm{R} 1^{1,2)}$ & MK & $6 \mathrm{M} \mathrm{Na}$ & $11 / 3 / 10$ & 19.85 & 13.58 & 1.00 & 7.67 & 0.95 & 10.98 & 18.96 & 1.00 & 2.00 & 7.45 & 16.57 & 100.00 & 0.301 \\
\hline S1-6X4 & MK & $6 \mathrm{M} \mathrm{Na}$ & $11 / 09 / 10$ & 21.33 & 14.59 & 1.02 & 7.90 & 0.00 & 10.06 & 17.32 & 1.02 & 2.04 & 7.77 & 16.96 & 100.00 & 0.303 \\
\hline $\mathrm{S} 1-12 \mathrm{X} 2^{1,2)}$ & FS & $12 \mathrm{M} \mathrm{Na}$ & $11 / 10 / 10$ & 11.21 & 28.94 & 1.01 & 3.86 & 0.00 & 6.88 & 17.15 & 1.01 & 2.02 & 13.79 & 14.13 & 100.00 & 0.267 \\
\hline S1-4X3 & $\mathrm{MK}$ & $4 \mathrm{M} \mathrm{Na}$ & $11 / 16 / 10$ & 21.82 & 14.93 & 1.02 & 8.43 & 0.45 & 10.88 & 17.34 & 1.02 & 2.04 & 4.58 & 17.49 & 100.00 & 0.299 \\
\hline $\mathrm{S} 1-4 \mathrm{X} 4$ & FS & $4 \mathrm{M} \mathrm{Na}$ & $11 / 16 / 10$ & 12.23 & 31.56 & 1.01 & 4.73 & 1.72 & 7.85 & 17.19 & 1.01 & 2.02 & 4.44 & 16.23 & 100.00 & 0.270 \\
\hline $\mathrm{S} 1-6 \mathrm{X} 3 \mathrm{R}^{1,2)}$ & FS & $6 \mathrm{M} \mathrm{Na}$ & $11 / 16 / 10$ & 11.78 & 30.39 & 1.01 & 4.56 & 0.92 & 7.40 & 17.18 & 1.01 & 2.02 & 7.71 & 16.02 & 100.00 & 0.281 \\
\hline $\mathrm{S} 1-12 \mathrm{X} 1 \mathrm{R}^{1,2)}$ & MK & $12 \mathrm{M} \mathrm{Na}$ & $11 / 16 / 10$ & 18.83 & 12.88 & 1.01 & 4.69 & 0.00 & 9.14 & 17.19 & 1.01 & 2.02 & 16.40 & 16.83 & 100.00 & 0.354 \\
\hline $\mathrm{S} 1-12 \mathrm{X} 2 \mathrm{R}^{1,2)}$ & FS & $12 \mathrm{M} \mathrm{Na}$ & $11 / 16 / 10$ & 10.49 & 27.07 & 1.01 & 2.88 & 0.00 & 6.58 & 17.11 & 1.01 & 2.01 & 15.99 & 15.86 & 100.00 & 0.323 \\
\hline
\end{tabular}

1) 8 -12 ml high range water reducer (ADVA $140 \mathrm{M}$ ) per $1 \mathrm{~kg}$ geopolymer material was added to the paste, ${ }^{2)} 13-14 \mathrm{~g}$ of Ag-zeolite were replaced by the same amount of $\mathrm{AgNO}_{3}$ in a $4 \mathrm{~kg}$ batch 
Table 4.11. Properties of DuraLith Pastes and Products with Higher Waste Loading (S1).

\begin{tabular}{|c|c|c|c|c|c|c|c|c|c|c|}
\hline Sample I.D. & \begin{tabular}{|c|}
$\begin{array}{c}\text { Formulation } \\
\text { type }\end{array}$ \\
\end{tabular} & Waste & Date & $\mathbf{W} / \mathbf{C}$ & $\begin{array}{c}\text { Paste } \\
\text { characteristics }\end{array}$ & Bleeding & $\begin{array}{l}\text { Salt deposition } \\
\text { (after } 28 \text { days) }\end{array}$ & $\begin{array}{l}\text { Time to } \\
\text { harden }\end{array}$ & $\begin{array}{c}\text { Surface } \\
\text { cracking }\end{array}$ & $\begin{array}{c}28 \text { day Compressive } \\
\text { strength (psi) }\end{array}$ \\
\hline S1-8X1 & MK & $8 \mathrm{M} \mathrm{Na}$ & $9 / 21 / 10$ & 0.328 & Pours slowly & $<0.5 \mathrm{vol} . \%$ & Yes & $>157$ min & Yes & 11553 \\
\hline S1-8X2 & FS & $8 \mathrm{M} \mathrm{Na}$ & $9 / 21 / 10$ & 0.298 & Pours slowly & No & Yes & $\sim 170$ min & Yes & 17210 \\
\hline S1-8X1R ${ }^{1)}$ & MK & $8 \mathrm{M} \mathrm{Na}$ & $9 / 29 / 10$ & 0.299 & Spatula required & No & Little & $102 \min$ & No & 11703 \\
\hline S1-8X2R ${ }^{1)}$ & FS & $8 \mathrm{M} \mathrm{Na}$ & $9 / 29 / 10$ & 0.265 & Pours slowly & No & Little & $>134 \min$ & No & 16724 \\
\hline S1-5X1 ${ }^{1)}$ & FS & $5 \mathrm{M} \mathrm{Na}$ & $10 / 1 / 10$ & 0.265 & Easily pourable & No & No & $>145 \min$ & No & 15013 \\
\hline S1-5X2 ${ }^{1)}$ & MK & $5 \mathrm{M} \mathrm{Na}$ & $10 / 1 / 10$ & 0.292 & Easily pourable & No & No & $>129 \min$ & No & 12308 \\
\hline S1-6X1R1 ${ }^{1)}$ & FS & $6 \mathrm{M} \mathrm{Na}$ & $11 / 3 / 10$ & 0.273 & Spatula required & No & Little & $60 \mathrm{~min}$ & Little & 12117 \\
\hline S1-6X2R1 1) & MK & $6 \mathrm{M} \mathrm{Na}$ & $11 / 3 / 10$ & 0.301 & Pours slowly & No & Yes & $78 \mathrm{~min}$ & No & 11805* \\
\hline S1-6X1R ${ }^{1)}$ & FS & $6 \mathrm{M} \mathrm{Na}$ & $10 / 6 / 10$ & 0.273 & Pours slowly & No & No & $\sim 115$ min & No & 18890 \\
\hline S1-6X2R ${ }^{1)}$ & MK & $6 \mathrm{M} \mathrm{Na}$ & $10 / 6 / 10$ & 0.301 & Pours slowly & No & No & $\sim 110$ min & No & 11000 \\
\hline S1-4X1R3 & MK & $4 \mathrm{M} \mathrm{Na}$ & $10 / 6 / 10$ & 0.313 & Easily pourable & No & No & $>80 \min$ & No & 10044 \\
\hline S1-4X2R1 & FS & $4 \mathrm{M} \mathrm{Na}$ & $10 / 6 / 10$ & 0.292 & Easily pourable & No & No & $>95 \min$ & No & 18639 \\
\hline S1-6X4 & MK & $6 \mathrm{M} \mathrm{Na}$ & $11 / 09 / 10$ & 0.303 & Spatula required & No & No & $65 \min$ & No & 14389 \\
\hline $\mathrm{S} 1-12 \mathrm{X} 2^{1)}$ & FS & $12 \mathrm{M} \mathrm{Na}$ & $11 / 10 / 10$ & 0.267 & Easily pourable & No & No & $140 \mathrm{~min}$ & No & 11490 \\
\hline S1-4X3 & MK & $4 \mathrm{M} \mathrm{Na}$ & $11 / 16 / 10$ & 0.299 & Pours slowly & No & No & $80 \min$ & No & 12612 \\
\hline $\mathrm{S} 1-4 \mathrm{X} 4$ & FS & $4 \mathrm{M} \mathrm{Na}$ & $11 / 16 / 10$ & 0.270 & Pours slowly & No & No & $90 \min$ & No & 19500 \\
\hline S1-6X3R ${ }^{1)}$ & FS & $6 \mathrm{M} \mathrm{Na}$ & $11 / 16 / 10$ & 0.281 & Spatula required & No & No & $77 \mathrm{~min}$ & No & 19180 \\
\hline S1-12X1R ${ }^{1)}$ & MK & $12 \mathrm{M} \mathrm{Na}$ & $11 / 16 / 10$ & 0.354 & Pours slowly & No & No & $90 \mathrm{~min}$ & No & $>11860$ \\
\hline S1-12X2R ${ }^{1)}$ & FS & $12 \mathrm{M} \mathrm{Na}$ & $11 / 16 / 10$ & 0.323 & Pours slowly & No & No & $70 \mathrm{~min}$ & No & $7956 * *$ \\
\hline
\end{tabular}

1) $8-12 \mathrm{ml}$ high range water reducer (ADVA $140 \mathrm{M}$ ) per $1 \mathrm{~kg}$ geopolymer material was added to the paste

* Domed surface

** $100 \mathrm{ml}$ additional water was added during mixing 
Table 4.12. Compositions of DuraLith Product with Higher Waste Loading (S4) (wt\%)*.

\begin{tabular}{|c|c|c|c|c|c|c|c|c|c|c|c|c|c|c|c|c|}
\hline \multirow{2}{*}{$\begin{array}{c}\text { Sample } \\
\text { I.D. }\end{array}$} & \multirow{2}{*}{$\begin{array}{c}\text { Formulation } \\
\text { type }\end{array}$} & \multirow{2}{*}{ Waste } & \multirow{2}{*}{ Date } & \multirow{2}{*}{ MK } & \multirow{2}{*}{ BFS } & \multirow{2}{*}{$\begin{array}{c}\text { SF } \\
\text { filler }\end{array}$} & \multicolumn{3}{|c|}{ Activator } & \multirow{2}{*}{ Sand } & \multirow{2}{*}{$\begin{array}{l}\text { Enhancer } \\
\text { for I, Ag-Z }\end{array}$} & \multirow{2}{*}{$\begin{array}{c}\text { Copper } \\
\text { Slag }\end{array}$} & \multicolumn{2}{|c|}{ HSW } & \multirow{2}{*}{ Sum } & \multirow{2}{*}{$\mathbf{W} / \mathbf{C}$} \\
\hline & & & & & & & $\mathbf{K}_{2} \mathbf{O}$ & $\mathrm{Na}_{2} \mathrm{O}$ & $\mathrm{SiO}_{2}$ & & & & Solids & Water & & \\
\hline S4-4X1 & FS & $4 \mathrm{M} \mathrm{Na}$ & $11 / 23 / 10$ & 10.92 & 28.18 & 1.00 & 5.17 & 2.15 & 7.01 & 19.00 & 1.00 & 2.00 & 8.01 & 15.55 & 100.00 & 0.271 \\
\hline S4-4X2 & MK & $4 \mathrm{M} \mathrm{Na}$ & $11 / 23 / 10$ & 19.08 & 13.05 & 1.00 & 9.02 & 1.01 & 9.58 & 19.00 & 1.00 & 2.00 & 8.50 & 16.75 & 100.00 & 0.300 \\
\hline S4-6X1 & MK & $6 \mathrm{M} \mathrm{Na}$ & $11 / 22 / 10$ & 9.80 & 25.28 & 1.00 & 4.63 & 1.90 & 6.28 & 19.00 & 1.00 & 2.00 & 14.16 & 14.95 & 100.00 & 0.288 \\
\hline S4-6X2 & FS & $6 \mathrm{M} \mathrm{Na}$ & $11 / 22 / 10$ & 16.99 & 11.62 & 1.00 & 8.04 & 0.87 & 8.47 & 19.00 & 1.00 & 2.00 & 15.26 & 15.75 & 100.00 & 0.315 \\
\hline
\end{tabular}

* About $10 \mathrm{~g}$ of the added Ag zeolite was replaced by $10 \mathrm{~g} \mathrm{AgNO}_{3}$ in a $4 \mathrm{~kg}$ batch. ADVA 140M was added to S4-6X1 and S4-6X2.

Table 4.13. Properties of DuraLith Product Compositions with Higher Waste Loading (S4).

\begin{tabular}{|c|c|c|c|c|c|c|c|c|c|c|c|c|}
\hline \multirow[t]{2}{*}{ Sample I.D. } & \multirow[t]{2}{*}{ Type } & \multirow[t]{2}{*}{ Waste } & \multirow[t]{2}{*}{ Date } & \multirow[t]{2}{*}{$\mathrm{W} / \mathrm{C}$} & \multirow{2}{*}{$\begin{array}{c}\text { Paste } \\
\text { characteristics }\end{array}$} & \multirow[t]{2}{*}{ Bleeding } & \multicolumn{2}{|c|}{$\begin{array}{c}\text { Salt deposition } \\
\text { Time (days) }\end{array}$} & \multirow{2}{*}{$\begin{array}{l}\text { Time to } \\
\text { harden }\end{array}$} & \multirow{2}{*}{$\begin{array}{l}\text { Surface } \\
\text { cracking }\end{array}$} & \multicolumn{2}{|c|}{$\begin{array}{c}\text { Compressive strength (psi) } \\
\text { Time (days) } \\
\end{array}$} \\
\hline & & & & & & & 7 & 45 & & & 7 & 45 \\
\hline S4-4X1 & FS & $4 \mathrm{M} \mathrm{Na}$ & $12 / 6 / 10$ & 0.271 & Pours slowly & $<0.3$ vol.\% & No & No & 166 min & No & 7103 & 10379 \\
\hline $\mathrm{S} 4-4 \mathrm{X} 2$ & MK & $4 \mathrm{M} \mathrm{Na}$ & $12 / 6 / 10$ & 0.300 & Pours slowly & $<0.1$ vol. $\%$ & No & No & 146 min & No & 10636 & 10988 \\
\hline S4-6X1 & MK & $6 \mathrm{M} \mathrm{Na}$ & $12 / 6 / 10$ & 0.288 & Pours slowly & No & No & No & $180 \mathrm{~min}$ & No & 3870 & 5350 \\
\hline S4-6X2 & FS & $6 \mathrm{M} \mathrm{Na}$ & $12 / 6 / 10$ & 0.315 & Pours slowly & No & No & No & 131 min & No & 6601 & 7003 \\
\hline
\end{tabular}


Table 4.14. TCLP Results (Hazardous Elements, Cu, and Sn, mg/L) in DuraLith Products for Water Optimization (Waste S1, 2M Na).

\begin{tabular}{|c|c|c|c|c|c|c|c|c|c|c|}
\hline \multirow[t]{2}{*}{ Sample I.D. } & $\begin{array}{c}\begin{array}{c}\text { Formulation } \\
\text { type }\end{array} \\
\end{array}$ & Date & $\mathbf{W} / \mathbf{C}$ & \multirow{2}{*}{$\begin{array}{r}\text { Ag } \\
0.14 \\
\end{array}$} & \multirow{2}{*}{$\begin{array}{c}\text { As } \\
5.0\end{array}$} & \multirow{2}{*}{$\begin{array}{c}\text { Cd } \\
0.11\end{array}$} & \multirow{2}{*}{$\begin{array}{c}\text { Cr } \\
0.60\end{array}$} & \multirow{2}{*}{$\frac{\mathbf{C u}}{\mathrm{N} / \mathrm{A}}$} & \multirow{2}{*}{$\begin{array}{c}\mathbf{P b} \\
0.75\end{array}$} & \multirow{2}{*}{$\begin{array}{c}\text { Sn } \\
\text { N/A }\end{array}$} \\
\hline & EP & imit [20] & & & & & & & & \\
\hline S1-2X2A & MK & $7 / 30 / 10$ & 0.365 & $<0.07$ & $<0.20$ & $<0.03$ & 0.01 & $<0.02$ & 0.12 & $<0.25$ \\
\hline S1-2X2B & MK & $7 / 30 / 10$ & 0.365 & $<0.07$ & $<0.20$ & $<0.03$ & 0.02 & $<0.02$ & 0.12 & $<0.25$ \\
\hline S1-2X3 & MK & $8 / 3 / 10$ & 0.352 & $<0.07$ & $<0.20$ & $<0.03$ & 0.02 & $<0.02$ & 0.13 & $<0.25$ \\
\hline S1-2X5 & FS & $8 / 5 / 10$ & 0.288 & $<0.07$ & $<0.20$ & $<0.03$ & $<0.01$ & $<0.02$ & 0.15 & $<0.25$ \\
\hline S1-2X8 & FS & $8 / 11 / 10$ & 0.296 & $<0.07$ & $<0.20$ & $<0.03$ & $<0.01$ & $<0.02$ & 0.19 & $<0.25$ \\
\hline S1-2X10R & FS & $8 / 20 / 10$ & 0.288 & $<0.07$ & $<0.20$ & $<0.03$ & $<0.01$ & $<0.02$ & 0.30 & $<0.25$ \\
\hline S1-2X12 & FS & $8 / 25 / 10$ & 0.278 & $<0.07$ & $<0.20$ & $<0.03$ & 0.02 & $<0.02$ & 0.18 & $<0.25$ \\
\hline $\mathrm{S} 1-2 \mathrm{X} 13$ & MK & $8 / 25 / 10$ & 0.304 & $<0.07$ & $<0.20$ & $<0.03$ & 0.01 & $<0.02$ & $<0.10$ & $<0.25$ \\
\hline S1-2X14* & FS & $8 / 31 / 10$ & 0.285 & $<0.07$ & $<0.20$ & $<0.03$ & 0.02 & $<0.02$ & 0.23 & $<0.25$ \\
\hline S1-2X15 & MK & $8 / 31 / 10$ & 0.303 & $<0.07$ & $<0.20$ & $<0.03$ & 0.01 & $<0.02$ & $<0.10$ & $<0.25$ \\
\hline
\end{tabular}

N/A - Not Applicable

* Sample selected for ANS 16.1 testing 
Table 4.15. TCLP Results (Hazardous Elements, Cu, and Sn, mg/L) in DuraLith Products (Wastes S2-, S3-, S4, 2 M Na).

\begin{tabular}{|c|c|c|c|c|c|c|c|c|c|c|}
\hline \multirow{2}{*}{ Sample I.D. } & $\begin{array}{c}\begin{array}{c}\text { Formulation } \\
\text { type }\end{array} \\
\end{array}$ & Date & $\mathrm{W} / \mathrm{C}$ & \multirow{2}{*}{$\begin{array}{c}\text { Ag } \\
0.14\end{array}$} & \multirow{2}{*}{$\begin{array}{c}\text { As } \\
5.0\end{array}$} & \multirow{2}{*}{$\begin{array}{c}\text { Cd } \\
0.11\end{array}$} & \multirow{2}{*}{$\begin{array}{c}\text { Cr } \\
0.60 \\
\end{array}$} & \multirow{2}{*}{$\begin{array}{c}\mathbf{C u} \\
\text { N/A }\end{array}$} & \multirow{2}{*}{$\begin{array}{c}\mathbf{P b} \\
0.75\end{array}$} & \multirow{2}{*}{$\begin{array}{c}\text { Sn } \\
\text { N/A }\end{array}$} \\
\hline & $\mathrm{EP}$ & mits [20] & & & & & & & & \\
\hline $\mathrm{S} 2-2 \mathrm{X} 1$ & MK & $8 / 19 / 10$ & 0.303 & $<0.07$ & $<0.20$ & $<0.03$ & 0.01 & $<0.02$ & 0.11 & $<0.25$ \\
\hline S2-2X4 & FS & $8 / 19 / 10$ & 0.282 & $<0.07$ & $<0.20$ & $<0.03$ & 0.02 & $<0.02$ & 0.21 & $<0.25$ \\
\hline S2-2X4R & FS & $9 / 17 / 10$ & 0.273 & $<0.07$ & $<0.20$ & $<0.03$ & 0.02 & $<0.02$ & 0.16 & $<0.25$ \\
\hline S3-2X1R & MK & $8 / 20 / 10$ & 0.307 & $<0.07$ & $<0.20$ & $<0.03$ & 0.01 & $<0.02$ & 0.11 & $<0.25$ \\
\hline S3-2X2R & $\mathrm{FS}$ & $8 / 20 / 10$ & 0.283 & $<0.07$ & $<0.20$ & $<0.03$ & 0.02 & $<0.02$ & 0.26 & $<0.25$ \\
\hline S4-2X1 & MK & $8 / 19 / 10$ & 0.310 & $<0.07$ & $<0.20$ & $<0.03$ & 0.02 & $<0.02$ & 0.19 & $<0.25$ \\
\hline S4-2X4 & FS & $8 / 19 / 10$ & 0.286 & $<0.07$ & $<0.20$ & $<0.03$ & 0.03 & $<0.02$ & 0.32 & $<0.25$ \\
\hline
\end{tabular}

NA - Not Applicable 
Table 4.16. TCLP Results (Hazardous Elements, $\mathrm{Cu}$, and Sn, $\mathrm{mg} / \mathrm{L}$ ) in DuraLith Products with Combinations of Enhancers and Other Additives (Waste S1, 2 M Na).

\begin{tabular}{|c|c|c|c|c|c|c|c|c|c|c|}
\hline \multirow{2}{*}{ Sample I.D. } & $\begin{array}{c}\begin{array}{c}\text { Formulation } \\
\text { type }\end{array} \\
\end{array}$ & Date & $\mathbf{W} / \mathbf{C}$ & Ag & As & Cd & Cr & $\mathbf{C u}$ & $\mathbf{P b}$ & Sn \\
\hline & \multicolumn{3}{|c|}{ EPA Limits [20] } & 0.14 & 5.0 & 0.11 & 0.60 & N/A & 0.75 & N/A \\
\hline S1-2X12R1 & FS & $9 / 1 / 10$ & 0.278 & $<0.07$ & $<0.20$ & $<0.03$ & 0.01 & $<0.02$ & 0.25 & $<0.25$ \\
\hline S1-2X12R2 & FS & $9 / 1 / 10$ & 0.278 & $<0.07$ & $<0.20$ & $<0.03$ & 0.01 & $<0.02$ & 0.23 & $<0.25$ \\
\hline S1-2X13R1 & MK & $9 / 1 / 10$ & 0.304 & $<0.07$ & $<0.20$ & $<0.03$ & $<0.01$ & $<0.02$ & 0.14 & $<0.25$ \\
\hline S1-2X13R2* & MK & $9 / 1 / 10$ & 0.304 & $<0.07$ & $<0.20$ & $<0.03$ & $<0.01$ & $<0.02$ & 0.11 & $<0.25$ \\
\hline S1-2X18 & FS, Copper slag & $9 / 21 / 10$ & 0.253 & $<0.07$ & $<0.20$ & $<0.03$ & 0.01 & $<0.02$ & 0.16 & $<0.25$ \\
\hline S1-2X19 & MK, Copper slag & $9 / 21 / 10$ & 0.276 & $<0.07$ & $<0.20$ & $<0.03$ & 0.02 & $<0.02$ & 0.12 & $<0.25$ \\
\hline
\end{tabular}

NA - Not Applicable

* Sample selected for ANS 16.1 testing 
Table 4.17. TCLP Results (Hazardous Elements, $\mathrm{Cu}$, and Sn, mg/L) in DuraLith Products (Robustness Tests).

\begin{tabular}{|c|c|c|c|c|c|c|c|c|c|c|}
\hline \multirow{2}{*}{ Sample I.D. } & Variation & Date & $\mathbf{W} / \mathbf{C}$ & \multirow{2}{*}{$\begin{array}{c}\text { Ag } \\
0.14 \\
\end{array}$} & \multirow{2}{*}{$\begin{array}{c}\text { As } \\
5.0 \\
\end{array}$} & \multirow{2}{*}{$\begin{array}{c}\text { Cd } \\
0.11 \\
\end{array}$} & \multirow{2}{*}{$\begin{array}{c}\mathbf{C r} \\
0.60\end{array}$} & \multirow{2}{*}{$\begin{array}{c}\mathbf{C u} \\
\text { N/A } \\
\end{array}$} & \multirow{2}{*}{$\begin{array}{c}\mathbf{P b} \\
0.75 \\
\end{array}$} & \multirow{2}{*}{$\begin{array}{c}\text { Sn } \\
\text { N/A } \\
\end{array}$} \\
\hline & EPA & nits [20] & & & & & & & & \\
\hline S1-2XV1 & Baseline & $10 / 8 / 10$ & 0.278 & $<0.07$ & $<0.20$ & $<0.03$ & 0.02 & 0.03 & 0.21 & $<0.25$ \\
\hline S1-2XV2 & $-10 \% \mathrm{FS}$ & $10 / 8 / 10$ & 0.293 & $<0.07$ & $<0.20$ & $<0.03$ & 0.02 & 0.03 & 0.22 & $<0.25$ \\
\hline S1-2XV4 & $-10 \% \mathrm{KOH}$ & $10 / 8 / 10$ & 0.280 & $<0.07$ & $<0.20$ & $<0.03$ & 0.02 & $<0.02$ & 0.19 & $<0.25$ \\
\hline S1-2XV5 & $+10 \% \mathrm{MK}$ & $10 / 14 / 10$ & 0.273 & $<0.07$ & $<0.20$ & $<0.03$ & 0.02 & $<0.02$ & 0.19 & $<0.25$ \\
\hline S1-2XV6 & $+10 \% \mathrm{FS}$ & $10 / 14 / 10$ & 0.265 & $<0.07$ & $<0.20$ & $<0.03$ & 0.01 & $<0.02$ & 0.16 & $<0.25$ \\
\hline S1-2XV7 & $+10 \% \mathrm{SF}$ & $10 / 14 / 10$ & 0.275 & $<0.07$ & $<0.20$ & $<0.03$ & 0.01 & $<0.02$ & 0.14 & $<0.25$ \\
\hline S1-2XV8 & $+10 \% \mathrm{KOH}$ & $10 / 14 / 10$ & 0.275 & $<0.07$ & $<0.20$ & $<0.03$ & 0.01 & $<0.02$ & 0.16 & $<0.25$ \\
\hline
\end{tabular}

NA - Not Applicable 
Table 4.18. TCLP Results (Hazardous Elements, Cu, and Sn, mg/L) in DuraLith Products with Higher Waste Loading (Waste S1).

\begin{tabular}{|c|c|c|c|c|c|c|c|c|c|c|c|}
\hline \multirow[t]{2}{*}{ Sample I.D. } & $\begin{array}{c}\text { Formulation } \\
\text { type }\end{array}$ & Waste & Date & W/C & \multirow{2}{*}{$\begin{array}{c}\text { Ag } \\
0.14\end{array}$} & \multirow{2}{*}{$\begin{array}{c}\text { As } \\
5.0\end{array}$} & \multirow{2}{*}{$\begin{array}{c}\text { Cd } \\
0.11\end{array}$} & \multirow{2}{*}{$\begin{array}{c}\mathbf{C r} \\
0.60\end{array}$} & \multirow{2}{*}{$\begin{array}{c}\mathbf{C u} \\
\text { N/A }\end{array}$} & \multirow{2}{*}{$\begin{array}{c}\mathbf{P b} \\
0.75\end{array}$} & \multirow{2}{*}{$\begin{array}{c}\text { Sn } \\
\text { N/A }\end{array}$} \\
\hline & & PA Limi & & & & & & & & & \\
\hline S1-8X1 & MK & $8 \mathrm{M} \mathrm{Na}$ & $9 / 21 / 10$ & 0.328 & $<0.07$ & $<0.20$ & $<0.03$ & $<0.01$ & $<0.02$ & $<0.10$ & $<0.25$ \\
\hline S1-8X2 & FS & $8 \mathrm{M} \mathrm{Na}$ & $9 / 21 / 10$ & 0.298 & $<0.07$ & $<0.20$ & $<0.03$ & $<0.01$ & $<0.02$ & $<0.10$ & $<0.25$ \\
\hline S1-8X1R ${ }^{1)}$ & MK & $8 \mathrm{M} \mathrm{Na}$ & 9/29/10 & 0.299 & $<0.07$ & $<0.20$ & $<0.03$ & $<0.01$ & $<0.02$ & $<0.10$ & $<0.25$ \\
\hline S1-8X2R ${ }^{1)}$ & FS & $8 \mathrm{M} \mathrm{Na}$ & 9/29/10 & 0.265 & $<0.07$ & $<0.20$ & $<0.03$ & $<0.01$ & $<0.02$ & $<0.10$ & $<0.25$ \\
\hline $\mathrm{S} 1-5 \mathrm{X} 2^{1)}$ & MK & $5 \mathrm{M} \mathrm{Na}$ & $10 / 1 / 10$ & 0.292 & $<0.07$ & $<0.20$ & $<0.03$ & $<0.01$ & $<0.02$ & 0.14 & $<0.25$ \\
\hline S1-6X1R ${ }^{1)}$ & FS & $6 \mathrm{M} \mathrm{Na}$ & $10 / 6 / 10$ & 0.273 & $<0.07$ & $<0.20$ & $<0.03$ & $<0.01$ & $<0.02$ & 0.13 & $<0.25$ \\
\hline S1-6X2R ${ }^{1)}$ & MK & $6 \mathrm{M} \mathrm{Na}$ & $10 / 6 / 10$ & 0.301 & $<0.07$ & $<0.20$ & $<0.03$ & $<0.01$ & $<0.02$ & 0.12 & $<0.25$ \\
\hline S1-4X1R3 & MK & $4 \mathrm{M} \mathrm{Na}$ & $10 / 6 / 10$ & 0.313 & $<0.07$ & $<0.20$ & $<0.03$ & $<0.01$ & $<0.02$ & 0.16 & $<0.25$ \\
\hline S1-4X2R1 & FS & $4 \mathrm{M} \mathrm{Na}$ & $10 / 6 / 10$ & 0.292 & $<0.07$ & $<0.20$ & $<0.03$ & 0.01 & $<0.02$ & 0.15 & $<0.25$ \\
\hline
\end{tabular}

NA - Not Applicable

1) Doped with high range water reducer at 800-1200 ml/100 kg dry product 
Table 4.19. TCLP Results for Re.

\begin{tabular}{|c|c|c|c|c|c|c|c|}
\hline \multirow[b]{2}{*}{ Test } & \multirow[b]{2}{*}{ Sample I.D. } & \multirow{2}{*}{$\begin{array}{c}\text { Formulation } \\
\text { type }\end{array}$} & \multirow[b]{2}{*}{ Enhancer } & \multirow[b]{2}{*}{ Date } & \multicolumn{3}{|c|}{ Rhenium } \\
\hline & & & & & $\begin{array}{l}\text { Inventory } \\
\text { (mg/100g) }\end{array}$ & $\begin{array}{l}\text { in TCLP } \\
\text { (mg/L)* }\end{array}$ & \%Leached \\
\hline \multirow{10}{*}{ 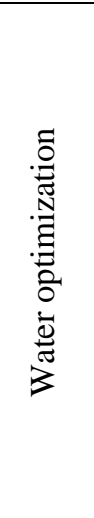 } & S1-2X2A & MK & $\mathrm{Ag}-\mathrm{Z}+\mathrm{Na}_{2} \mathrm{~S}$ & 7/30/10 & 3.21 & 1.02 & 63.6 \\
\hline & S1-2X2B & MK & $\mathrm{Ag}-\mathrm{Z}+\mathrm{Na}_{2} \mathrm{~S}$ & $7 / 30 / 10$ & 3.21 & 0.89 & 55.5 \\
\hline & S1-2X3 & MK & $\mathrm{Ag}-\mathrm{Z}+\mathrm{Na}_{2} \mathrm{~S}$ & $8 / 3 / 10$ & 3.10 & 0.23 & 14.8 \\
\hline & S1-2X5 & FS & Ag-Z+SnF 2 & $8 / 5 / 10$ & 3.34 & 0.16 & 61.0 \\
\hline & $\mathrm{S} 1-2 \mathrm{X} 8$ & FS & Ag-Z+SnF 2 & $8 / 11 / 10$ & 2.64 & 0.19 & 18.9 \\
\hline & S1-2X10R & FS & Ag-Z+SnF 2 & $8 / 20 / 10$ & 2.60 & 0.36 & 27.7 \\
\hline & S1-2X12 & FS & $\mathrm{Ag}-\mathrm{Z}+\mathrm{Na}_{2} \mathrm{~S}$ & $8 / 25 / 10$ & 2.44 & 0.25 & 20.2 \\
\hline & $\mathrm{S} 1-2 \mathrm{X} 13$ & MK & $\mathrm{Ag}-\mathrm{Z}+\mathrm{Na}_{2} \mathrm{~S}$ & $8 / 25 / 10$ & 2.58 & 0.24 & 18.3 \\
\hline & $\mathrm{S} 1-2 \mathrm{X} 14^{* *}$ & FS & Ag-Z+SnF 2 & $8 / 31 / 10$ & 1.90 & 0.21 & 22.1 \\
\hline & S1-2X15 & MK & Ag-Z+SnF 2 & $8 / 31 / 10$ & 1.89 & 0.15 & 15.7 \\
\hline \multirow{4}{*}{ 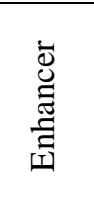 } & S1-2X12R1 & FS & $\mathrm{Ag}-\mathrm{Z}+\mathrm{Na}_{2} \mathrm{~S}$ & $9 / 1 / 10$ & 2.51 & 0.19 & 15.1 \\
\hline & S1-2X13R1 & MK & $\mathrm{Ag}-\mathrm{Z}+\mathrm{Na}_{2} \mathrm{~S}$ & $9 / 1 / 10$ & 2.58 & 0.34 & 26.0 \\
\hline & S1-2X12R2 & FS & $\mathrm{Ag}-\mathrm{Z}+\mathrm{SnF}_{2}$ & $9 / 1 / 10$ & 2.51 & 0.18 & 14.4 \\
\hline & S1-2X13R2** & MK & $\mathrm{Ag}-\mathrm{Z}+\mathrm{SnF}_{2}$ & $9 / 1 / 10$ & 2.58 & 0.22 & 17.2 \\
\hline \multirow{2}{*}{ 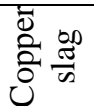 } & S1-2X18 & FS & Ag-Z+SnF ${ }_{2}+$ Copper Slag & $9 / 21 / 10$ & 2.56 & 0.20 & 15.8 \\
\hline & S1-2X19 & MK & Ag-Z+SnF ${ }_{2}+$ Copper Slag & $9 / 21 / 10$ & 2.63 & 0.07 & 5.4 \\
\hline \multirow{7}{*}{ 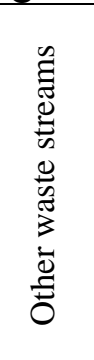 } & $\mathrm{S} 2-2 \mathrm{X} 1$ & MK & $\mathrm{Ag}-\mathrm{Z}+\mathrm{SnF}_{2}$ & $8 / 19 / 10$ & 2.56 & 0.13 & 10.4 \\
\hline & $\mathrm{S} 2-2 \mathrm{X} 4$ & $\mathrm{FS}$ & $\mathrm{Ag}-\mathrm{Z}+\mathrm{SnF}_{2}$ & $8 / 19 / 10$ & 2.53 & 0.20 & 15.5 \\
\hline & S2-2X4R & FS & Ag-Z+SnF 2 & $9 / 17 / 10$ & 2.43 & 0.20 & 16.2 \\
\hline & S3-2X1R & MK & $\mathrm{Ag}-\mathrm{Z}+\mathrm{SnF}_{2}$ & $8 / 20 / 10$ & 2.63 & 0.23 & 17.4 \\
\hline & S3-2X2R & FS & $\mathrm{Ag}-\mathrm{Z}+\mathrm{SnF}_{2}$ & $8 / 20 / 10$ & 2.58 & 0.39 & 30.2 \\
\hline & S4-2X1 & MK & Ag-Z+SnF 2 & $8 / 19 / 10$ & 1.90 & 0.27 & 28.4 \\
\hline & $\mathrm{S} 4-2 \mathrm{X} 4$ & FS & $\mathrm{Ag}-\mathrm{Z}+\mathrm{SnF}_{2}$ & $8 / 19 / 10$ & 1.86 & 0.26 & 27.9 \\
\hline
\end{tabular}

*The reporting limit for Re is $0.25 \mathrm{mg} / \mathrm{L}$. Errors in the values below $0.25 \mathrm{mg} / \mathrm{L}$ may be larger than $10 \%$ ** Samples selected for ANS 16.1 
Table 4.19. TCLP Results for Re (continued).

\begin{tabular}{|c|c|c|c|c|c|c|c|}
\hline \multirow[b]{2}{*}{ Test } & \multirow[b]{2}{*}{ Sample I.D. } & \multirow{2}{*}{$\begin{array}{c}\text { Formulation } \\
\text { type }\end{array}$} & \multirow[b]{2}{*}{ Enhancer } & \multirow[b]{2}{*}{ Date } & \multicolumn{3}{|c|}{ Rhenium } \\
\hline & & & & & $\begin{array}{l}\text { Inventory } \\
(\mathrm{mg} / 100 \mathrm{~g})\end{array}$ & $\begin{array}{c}\text { in TCLP } \\
(\mathrm{mg} / \mathrm{L})\end{array}$ & \%Leached \\
\hline \multirow{8}{*}{ 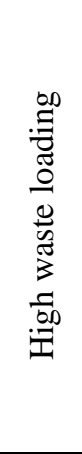 } & S1-8X1 & MK & $\mathrm{Ag}-\mathrm{Z}+\mathrm{SnF}_{2}$ & $9 / 21 / 10$ & 1.10 & 0.08 & 14.1 \\
\hline & $\mathrm{S} 1-8 \mathrm{X} 2$ & FS & Ag-Z+SnF 2 & $9 / 21 / 10$ & 1.06 & 0.29 & 54.4 \\
\hline & S1-8X1R & MK & $\mathrm{Ag}-\mathrm{Z}+\mathrm{SnF}_{2}$ & $9 / 29 / 10$ & 1.00 & 0.11 & 22.7 \\
\hline & S1-8X2R & FS & Ag-Z+SnF 2 & $9 / 29 / 10$ & 0.95 & 0.15 & 31.9 \\
\hline & S1-5X1 & FS & $\mathrm{Ag}-\mathrm{Z}+\mathrm{SnF}_{2}$ & $10 / 1 / 10$ & 0.61 & 0.15 & 49.0 \\
\hline & $\mathrm{S} 1-5 \mathrm{X} 2$ & MK & Ag-Z+SnF 2 & $10 / 1 / 10$ & 0.63 & 0.12 & 37.4 \\
\hline & S1-6X1R & FS & $\mathrm{Ag}-\mathrm{Z}+\mathrm{SnF}_{2}$ & $10 / 6 / 10$ & 0.78 & 0.11 & 27.6 \\
\hline & S1-6X2R & MK & Ag-Z+SnF 2 & $10 / 6 / 10$ & 0.80 & 0.11 & 21.5 \\
\hline \multirow{7}{*}{ 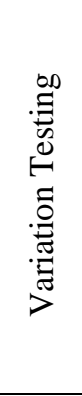 } & S1-2XV1 & Baseline & $\mathrm{Ag}-\mathrm{Z}+\mathrm{SnF}_{2}$ & $10 / 8 / 10$ & 0.23 & $<0.01$ & $<9.0$ \\
\hline & S1-2XV2 & $-10 \% \mathrm{FS}$ & $\mathrm{Ag}-\mathrm{Z}+\mathrm{SnF}_{2}$ & $10 / 8 / 10$ & 0.23 & $<0.01$ & $<9.0$ \\
\hline & S1-2XV4 & $-10 \% \mathrm{KOH}$ & $\mathrm{Ag}-\mathrm{Z}+\mathrm{SnF}_{2}$ & $10 / 8 / 10$ & 0.23 & 0.03 & 26.7 \\
\hline & S1-2XV5 & $+10 \% \mathrm{MK}$ & Ag-Z+SnF 2 & $10 / 14 / 10$ & 0.23 & 0.05 & 42.3 \\
\hline & S1-2XV6 & $+10 \% \mathrm{FS}$ & $\mathrm{Ag}-\mathrm{Z}+\mathrm{SnF}_{2}$ & $10 / 14 / 10$ & 0.23 & $<0.01$ & $<9.0$ \\
\hline & S1-2XV7 & $+10 \% \mathrm{SF}$ & $\mathrm{Ag}-\mathrm{Z}+\mathrm{SnF}_{2}$ & $10 / 14 / 10$ & 0.23 & $<0.01$ & $<9.0$ \\
\hline & S1-2XV8 & $+10 \% \mathrm{KOH}$ & $\mathrm{Ag}-\mathrm{Z}+\mathrm{SnF}_{2}$ & $10 / 14 / 10$ & 0.23 & $<0.01$ & $<9.0$ \\
\hline
\end{tabular}

The reporting lmit for Re is $0.25 \mathrm{mg} / \mathrm{L}$. Errors in the values below $0.25 \mathrm{mg} / \mathrm{L}$ may be larger than $10 \%$. 
Table 4.20. ANSI/ANS-16.1 Leaching Test Results.

\begin{tabular}{|c|c|c|c|c|}
\hline \multirow[t]{2}{*}{ Product (sample name) } & \multicolumn{2}{|c|}{ Concentration in $\mathrm{mg} / \mathrm{L}$} & \multicolumn{2}{|c|}{ Leachability Index } \\
\hline & $\mathrm{Na}$ & $\mathrm{Re}^{* * *}$ & $\mathrm{Na}$ & $\operatorname{Re}$ \\
\hline S1-2X13R2-7-L01 ${ }^{1)}$ & 4.559 & 0.0069 & 9.59 & 10.13 \\
\hline S1-2X13R2-7-L02 & 5.302 & 0.0034 & 9.33 & 10.63 \\
\hline S1-2X13R2-7-L03 & 9.907 & 0.0093 & 9.32 & 10.81 \\
\hline S1-2X13R2-7-L04 & 10.242 & 0.0178 & 9.20 & 9.26 \\
\hline S1-2X13R2-7-L05 & 7.864 & 0.0494 & 9.20 & 8.22 \\
\hline S1-2X13R2-7-L06 & 14.604 & 0.0492 & 8.51 & 8.06 \\
\hline S1-2X13R2-7-L07 & ND & ND & - & - \\
\hline S1-2X13R2-7-L08 & 90.86 & 0.0787 & 8.72 & 9.30 \\
\hline S1-2X13R2-7-L09 & 114.15 & 0.0830 & 8.61 & 9.45 \\
\hline S1-2X13R2-7-L10 & 127.11 & 0.0795 & 8.66 & 9.55 \\
\hline $\mathrm{S} 1-2 \mathrm{X} 14-\mathrm{L}^{2} 1^{2)}$ & 9.460 & 0.0073 & 9.49 & 9.84 \\
\hline S1-2X14-L02 & 12.035 & 0.0092 & 9.16 & 9.24 \\
\hline S1-2X14-L03 & 24.362 & 0.0026 & 9.07 & $*)$ \\
\hline S1-2X14-L04 & 22.675 & 0.0085 & 9.04 & 9.79 \\
\hline S1-2X14-L05 & 16.484 & 0.0050 & 9.09 & $*)$ \\
\hline S1-2X14-L06 & 7.112 & 0.0043 & 9.67 & *) \\
\hline S1-2X14-L07 & ND & ND & - & - \\
\hline S1-2X14-L08 & 69.34 & 0.0522 & 9.49 & 9.45 \\
\hline S1-2X14-L09 & 101.86 & 0.0804 & 9.30 & 9.27 \\
\hline S1-2X14-L10 & 92.384 & 0.0768 & 9.43 & 9.37 \\
\hline Blank ANS-L01 & 0.0022 & 0.0028 & N/A & N/A \\
\hline Blank ANS-L02 & -0.004 & 0.0014 & N/A & N/A \\
\hline Blank ANS-L03 & 0.0007 & 0.0063 & N/A & N/A \\
\hline Blank ANS-L04 & 0.0059 & 0.0017 & N/A & N/A \\
\hline Blank ANS-L05 & -0.001 & 0.0085 & N/A & N/A \\
\hline Blank ANS-L06 & 0.0035 & 0.0079 & N/A & N/A \\
\hline Blank ANS-L07 & ND & ND & N/A & N/A \\
\hline Blank ANS-L08 & 0.0358 & 0.006 & N/A & N/A \\
\hline Blank ANS-L09 & 0.0011 & 0.0057 & N/A & N/A \\
\hline Blank ANS-L10 & 0.0103 & 0.0063 & N/A & N/A \\
\hline
\end{tabular}

*) Concentration is negative after subtraction of blank; N/A not applicable. ${ }^{* * *}$ ) Concentrations below reporting limit of $0.25 \mathrm{mg} / \mathrm{L}$.

The analytical errors are $\pm 10 \%$ for values above the reporting limit and assumed to be $>10 \%$ below.

1) MK-based, 2) FS-based. ND = not determined. ${ }^{\$}$-Lxx suffix indicates sampling sequence per ANSI/ANS 16.1 
Table 4.21. Results of 'Free Water' Measurements in Cured DuraLith Products.

\begin{tabular}{|c|c|c|c|}
\hline Sample I.D. & Sample Age at Measurement & Mass of samples tested (g) & Free Water \\
\hline S1-4X5 & 7 days & 100.25 & No \\
\hline S1-4X5 Duplicate & 7 days & 100.58 & No \\
\hline S1-6X5 & 7 days & 100.00 & No \\
\hline S1-6X5 Duplicate & 7 days & 100.00 & No \\
\hline S1-6X6 & 7 days & 100.00 & No \\
\hline S1-6X6 Duplicate & 7 days & 100.00 & No \\
\hline
\end{tabular}


Table 4.22. Loss of Water During Curing (grams).

\begin{tabular}{|c|c|c|c|c|c|c|c|c|c|c|}
\hline \multirow{3}{*}{$\begin{array}{l}\text { Sample ID } \\
\text { S1-2X26-1 }\end{array}$} & \multirow{3}{*}{$\begin{array}{c}\begin{array}{c}\text { Mass after } \\
\text { demoulding }\end{array} \\
418.53\end{array}$} & \multirow{3}{*}{$\begin{array}{l}\text { Mass loss during } \\
\text { curing in mould } \\
-0.56\end{array}$} & \multicolumn{7}{|c|}{ Mass loss after demoulding for } & \multirow{2}{*}{$\begin{array}{l}\% \text { mass loss } \\
\text { lays }\end{array}$} \\
\hline & & & 1 days & 2 days & 3 days & 4 days & 7 days & 15 days & 63 days & \\
\hline & & & -0.95 & -1.07 & -1.31 & -1.54 & -1.88 & -2.75 & -8.20 & -1.96 \\
\hline S1-2X26-2 & 415.41 & -0.59 & -0.87 & -1.10 & -1.43 & -1.69 & -2.08 & -2.75 & - & - \\
\hline S1-2X26-4 & 421.76 & -0.44 & -0.97 & -1.21 & -1.48 & -1.79 & -2.13 & -2.78 & -8.85 & -2.10 \\
\hline S1-2X26-5 & 414.47 & -0.49 & -0.77 & -0.99 & -1.30 & -1.63 & -1.95 & -2.50 & -7.53 & -1.82 \\
\hline S1-2X26-7 & 417.50 & -0.78 & -1.08 & -1.26 & -1.72 & -2.00 & -2.27 & -2.86 & -8.86 & -2.12 \\
\hline S1-2X26-8 & 416.64 & -0.76 & -0.88 & -1.04 & -1.43 & -1.69 & -2.00 & -2.66 & -11.59 & -2.78 \\
\hline S1-2X26-9 & 413.93 & -0.74 & -0.74 & -0.96 & -1.23 & -1.66 & -1.96 & -2.61 & -8.83 & -2.13 \\
\hline \multicolumn{3}{|c|}{ Average } & -0.90 & -1.10 & -1.41 & -1.70 & -2.03 & -2.70 & -8.92 & -2.14 \\
\hline S1-2X27-1 & 398.98 & -0.83 & -9.98 & -13.05 & -17.11 & -20.31 & -25.57 & -31.96 & -39.63 & -9.93 \\
\hline S1-2X27-2 & 402.64 & -0.51 & -9.43 & -13.45 & -17.74 & -20.52 & -25.92 & -31.65 & -39.74 & -9.87 \\
\hline S1-2X27-4 & 399.68 & -0.99 & -6.60 & -10.18 & -15.18 & -19.16 & -25.26 & -31.12 & -38.65 & -9.67 \\
\hline S1-2X27-5 & 401.65 & -0.77 & -6.54 & -9.30 & -15.01 & -18.11 & -24.20 & -29.98 & -40.91 & -10.19 \\
\hline S1-2X27-6 & 399.12 & -0.83 & -8.59 & -11.75 & -16.42 & -19.86 & -26.63 & -31.64 & -39.08 & -9.79 \\
\hline S1-2X27-7 & 399.86 & -0.86 & -7.31 & -11.17 & -16.26 & $\begin{array}{l}-19.69 \\
\end{array}$ & -25.11 & -31.41 & - & - \\
\hline S1-2X27-9 & 395.02 & -1.15 & -8.72 & -12.65 & -16.32 & -19.27 & -26.10 & -32.57 & -39.06 & -9.89 \\
\hline S1-2X27-10 & 395.33 & -0.42 & -7.53 & -11.87 & -15.00 & -18.63 & -24.57 & -31.71 & -38.97 & -9.86 \\
\hline \multicolumn{3}{|c|}{ Average } & -7.63 & -11.38 & -15.92 & -19.29 & -25.51 & -31.48 & -39.33 & -9.86 \\
\hline S1-4X3-1 & 402.29 & -0.1 & -2.57 & -4.40 & -6.11 & -7.79 & -10.19 & -15.92 & -24.82 & -6.17 \\
\hline S1-4X3-4 & 394.45 & -0.2 & -3.25 & -5.24 & -7.03 & -8.74 & -11.67 & $\begin{array}{l}-16.92 \\
\end{array}$ & -25.45 & -6.45 \\
\hline S1-4X3-7 & 396.61 & -0.2 & -2.77 & -4.64 & -6.65 & -8.25 & -10.57 & -15.97 & -24.98 & -6.30 \\
\hline \multicolumn{3}{|c|}{ Average } & -2.86 & -4.76 & -6.60 & -8.26 & -10.81 & -16.27 & -25.08 & -6.31 \\
\hline S1-4X4-1 & 422.10 & 0.03 & -1.57 & -2.21 & -4.26 & -5.79 & -8.15 & -12.00 & -18.35 & -4.35 \\
\hline S1-4X4-4 & 422.24 & -0.14 & -1.31 & -2.66 & -4.56 & -5.92 & -7.88 & -12.02 & -19.18 & -4.54 \\
\hline S1-4X4-7 & 425.12 & -0.35 & -1.51 & -2.94 & -4.38 & -5.75 & -7.41 & -11.79 & -17.97 & -4.23 \\
\hline \multicolumn{3}{|c|}{ Average } & -1.46 & -2.60 & -4.40 & -5.82 & -7.81 & -11.94 & -18.50 & -4.37 \\
\hline S1-6X3R-1 & 411.91 & -0.44 & -2.32 & -3.65 & -4.54 & -6.47 & -9.81 & -13.77 & -19.31 & -4.69 \\
\hline S1-6X3R-4 & 412.30 & 0.03 & -1.28 & -2.78 & -4.51 & -6.44 & -8.83 & -13.31 & -19.62 & -4.76 \\
\hline S1-6X3R-7 & 417.76 & -0.41 & -2.66 & -4.00 & -5.61 & -6.77 & -9.89 & -13.95 & -20.04 & -4.80 \\
\hline \multicolumn{3}{|c|}{ Average } & -2.09 & -3.48 & -4.89 & -6.56 & -9.51 & -13.68 & -19.66 & -4.75 \\
\hline
\end{tabular}


Table 4.23a. Compositions of DuraLith Products for High Waste Loading Tests (S3) in wt\%*.

\begin{tabular}{|c|c|c|c|c|c|c|c|c|c|c|c|c|c|c|c|}
\hline \multirow{2}{*}{ Sample I.D. } & \multirow{2}{*}{$\begin{array}{c}\text { Formulation } \\
\text { Type }\end{array}$} & \multirow{2}{*}{ Date } & \multirow{2}{*}{ MK } & \multirow{2}{*}{ BFS } & \multirow{2}{*}{$\begin{array}{c}\text { SF } \\
\text { filler }\end{array}$} & \multicolumn{3}{|c|}{ Activator } & \multirow{2}{*}{ Sand } & \multirow{2}{*}{ Zeolite } & \multirow{2}{*}{\begin{tabular}{|c|} 
Copper \\
Slag
\end{tabular}} & \multicolumn{2}{|c|}{ HSW } & \multirow{2}{*}{ Sum } & \multirow{2}{*}{ W/C } \\
\hline & & & & & & $\mathbf{K}_{2} \mathbf{O}$ & $\mathrm{Na}_{2} \mathrm{O}$ & $\mathrm{SiO}_{2}$ & & & & \begin{tabular}{l|} 
Solids \\
\end{tabular} & Water & & \\
\hline $\begin{array}{c}\text { HSW- } \\
\text { 2XLG2 }\end{array}$ & FS & $11 / 23 / 10$ & 11.68 & 30.14 & 1.00 & 5.57 & 1.97 & 8.12 & 19.00 & 1.00 & 2.00 & 2.52 & 17.00 & 100.00 & 0.277 \\
\hline $\begin{array}{c}\text { HSW- } \\
2 X L G 3\end{array}$ & MK & $11 / 23 / 10$ & 20.62 & 14.11 & 1.00 & 9.75 & 0.65 & 11.41 & 19.00 & 1.00 & 2.00 & 2.61 & 17.85 & 100.00 & 0.295 \\
\hline
\end{tabular}

* 50 g sodium sulfide hydrate was added as enhancer for Re; ground zeolite type 5A to simulate Ag-Z

Table 4.23b. Ingredients and Target Masses for 2.5-gal DuraLith Samples for Heat Generation Tests (g).

\begin{tabular}{|c|c|c|c|c|}
\hline Order of Addition & Ingredients & Assay & $\begin{array}{c}\text { HSW-2XLG3 } \\
\text { Metakaolin Based }\end{array}$ & $\begin{array}{c}\text { HSW-2XLG2 } \\
\text { Furnace Slag Based }\end{array}$ \\
\hline $\mathbf{1}$ & S3 simulant (2M Na) & 1.000 & 3752.9 & 50.0 \\
\hline $\mathbf{2}$ & Sodium sulfide & 0.999 & 2179.4 & 1333.3 \\
\hline $\mathbf{3}$ & KOH & $0.999^{*}$ & 171.6 & 515.1 \\
\hline $\mathbf{3}$ & NaOH & 0.990 & 2405.9 & 1696.8 \\
\hline $\mathbf{4}$ & Fumed silica, activator & 1.000 & 4348.0 & 2440.4 \\
\hline $\mathbf{5}$ & Metakaolin & 0.960 & 2855.9 & 6045.4 \\
\hline $\mathbf{5}$ & Furnace slag & 0.960 & 3846.7 & 3811.4 \\
\hline $\mathbf{5}$ & Fine River sand & 1.000 & 202.5 & 200.6 \\
\hline $\mathbf{5}$ & Ground zeolite Type 5A & 1.000 & 404.9 & 201.2 \\
\hline $\mathbf{5}$ & Ground copper slag & 1.000 & 20217.8 & 200.6 \\
\hline $\mathbf{6}$ & SF filler & 1.000 & & 280.3 \\
\hline
\end{tabular}

* Assay is on a metals basis; may vary depending on water content. 
Table 4.24. Properties of Two 2.5 gal Batches of DuraLith Pastes (Heat Release).

\begin{tabular}{|c|c|c|c|c|c|c|c|}
\hline \multirow{2}{*}{ Paste } & \multirow{2}{*}{ Waste Type } & \multicolumn{2}{|c|}{ Hardening } & \multicolumn{3}{|c|}{ Max. Temp. } & \multirow{2}{*}{$\begin{array}{l}\text { Temp. after } \\
20 \text { hrs }\left({ }^{\circ} \mathrm{C}\right)\end{array}$} \\
\hline & & min & ${ }^{\circ} \mathrm{C}$ & $\left({ }^{\circ} \mathrm{C}\right)$ & After (hrs) & Duration (hrs) & \\
\hline FS-based & $\mathrm{S} 3,2 \mathrm{M} \mathrm{Na}$ & 80 & 35 & 102 & 3 & 1 & 40 \\
\hline MK-based & $\mathrm{S} 3,2 \mathrm{M} \mathrm{Na}$ & 40 & 46 & 107 & 2 & 2.5 & 43 \\
\hline FS-based & $\mathrm{S} 1,6 \mathrm{M} \mathrm{Na}$ & 148 & 32 & 95 & 6.5 & 1.25 & 40 \\
\hline
\end{tabular}


Table 5.1. Compositions of Candidate Formulations for Testing on a Larger Scale.

\begin{tabular}{|c|c|c|c|c|c|c|c|c|c|c|c|c|c|c|c|c|}
\hline \multirow{2}{*}{ Sample I.D. } & \multirow{2}{*}{$\begin{array}{c}\text { Formulation } \\
\text { Type }\end{array}$} & \multirow{2}{*}{ Waste } & \multirow{2}{*}{ Date } & \multirow{2}{*}{ MK } & \multirow{2}{*}{ BFS } & \multirow{2}{*}{$\begin{array}{l}\mathrm{SiO}_{2} \\
\text { filler }\end{array}$} & \multicolumn{3}{|c|}{ Activator } & \multirow{2}{*}{ Sand } & \multirow{2}{*}{$\begin{array}{c}\text { En- } \\
\text { hancer* }\end{array}$} & \multirow{2}{*}{\begin{tabular}{|c|} 
Copper \\
Slag
\end{tabular}} & \multicolumn{2}{|c|}{ HSW } & \multirow{2}{*}{ Sum } & \multirow{2}{*}{$\mathrm{W} / \mathrm{C}$} \\
\hline & & & & & & & $\mathbf{K}_{2} \mathbf{O}$ & $\mathrm{Na}_{2} \mathrm{O}$ & $\mathrm{SiO}_{2}$ & & & & Solids & Water & & \\
\hline S1-2X26 & FS & $2 \mathrm{M} \mathrm{Na}$ & $11 / 23 / 10$ & 11.77 & 30.38 & 1.00 & 5.62 & 2.02 & 8.25 & 19.00 & 1.00 & 2.00 & 2.21 & 16.75 & 100.00 & 0.270 \\
\hline S1-2X27 & MK & $2 \mathrm{M} \mathrm{Na}$ & $11 / 23 / 10$ & 21.27 & 14.55 & 1.00 & 10.15 & 0.82 & 12.04 & 17.00 & 1.00 & 2.00 & 2.32 & 17.85 & 100.00 & 0.284 \\
\hline S1-4X5 & MK & $4 \mathrm{M} \mathrm{Na}$ & $11 / 22 / 10$ & 20.33 & 13.91 & 1.00 & 9.62 & 0.21 & 10.15 & 19.00 & 1.00 & 2.00 & 5.03 & 17.75 & 100.00 & 0.305 \\
\hline S1-4X6 & FS & $4 \mathrm{M} \mathrm{Na}$ & $11 / 22 / 10$ & 11.43 & 29.50 & 1.00 & 5.41 & 1.39 & 7.33 & 19.00 & 1.00 & 2.00 & 4.94 & 17.00 & 100.00 & 0.288 \\
\hline S1-6X5 & FS & $6 \mathrm{M} \mathrm{Na}$ & $11 / 22 / 10$ & 11.15 & 28.77 & 1.00 & 5.28 & 0.75 & 7.16 & 19.00 & 1.00 & 2.00 & 7.94 & 15.95 & 100.00 & 0.279 \\
\hline S1-6X6 & MK & $6 \mathrm{M} \mathrm{Na}$ & $11 / 22 / 10$ & 19.86 & 13.59 & 1.00 & 8.74 & 0.00 & 9.92 & 19.00 & 1.00 & 2.00 & 8.14 & 16.75 & 100.00 & 0.298 \\
\hline S1-8X1R1 & MK & $8 \mathrm{M} \mathrm{Na}$ & $11 / 29 / 10$ & 19.99 & 13.68 & 1.00 & 7.81 & 0.00 & 9.97 & 19.00 & 1.00 & 0.00 & 10.90 & 16.65 & 100.00 & 0.312 \\
\hline S1-8X2R1 & FS & $8 \mathrm{M} \mathrm{Na}$ & $11 / 29 / 10$ & 11.16 & 28.80 & 1.00 & 5.28 & 0.10 & 7.16 & 19.00 & 1.00 & 0.00 & 10.65 & 15.85 & 100.00 & 0.291 \\
\hline
\end{tabular}

* Enhancer for I, Ag-Z (13 -15 g of Ag-Z was replaced by $13-15$ g AgNO $_{3}$ in a $4 \mathrm{~kg}$ batch)

Table 5.2. Properties of Pastes and DuraLith Products (Candidate Formulations).

\begin{tabular}{|c|c|c|c|c|c|c|c|c|c|c|c|}
\hline \multirow{2}{*}{ Sample I.D. } & \multirow{2}{*}{ Type } & \multirow{2}{*}{ Waste } & \multirow{2}{*}{ Date } & \multirow{2}{*}{ W/C } & \multirow{2}{*}{$\begin{array}{c}\text { Paste } \\
\text { Characteristics }\end{array}$} & \multirow{2}{*}{ Bleeding } & \multirow{2}{*}{$\begin{array}{r}\text { Salt deposition } \\
\text { (after } 28 \text { days) }\end{array}$} & \multirow{2}{*}{$\begin{array}{l}\text { Time to } \\
\text { Harden }\end{array}$} & \multirow{2}{*}{$\begin{array}{c}\text { Surface } \\
\text { Cracking }\end{array}$} & \multicolumn{2}{|c|}{$\begin{array}{c}\text { Compressive strength (psi) } \\
\text { Time (days) }\end{array}$} \\
\hline & & & & & & & & & & & $\begin{array}{l}\text { ys) } \\
45\end{array}$ \\
\hline $\mathrm{S} 1-2 \mathrm{X} 26$ & FS & $2 \mathrm{M} \mathrm{Na}$ & $11 / 23 / 10$ & 0.279 & Easily pourable & No & No & $65 \mathrm{~min}$ & No & 13770 & 20934 \\
\hline S1-2X27 & MK & $2 \mathrm{M} \mathrm{Na}$ & $11 / 23 / 10$ & 0.293 & Easily pourable & No & No & $90 \mathrm{~min}$ & No & 11910 & 15187 \\
\hline $\mathrm{S} 1-4 \mathrm{X} 5$ & MK & $4 \mathrm{M} \mathrm{Na}$ & $11 / 22 / 10$ & 0.305 & Easily pourable & No & No & $107 \mathrm{~min}$ & No & 13821 & 15847 \\
\hline S1-4X6 & FS & $4 \mathrm{M} \mathrm{Na}$ & $11 / 22 / 10$ & 0.288 & Easily pourable & No & No & $132 \mathrm{~min}$ & No & 14073 & 21074 \\
\hline S1-6X5 * & FS & $6 \mathrm{M} \mathrm{Na}$ & $11 / 22 / 10$ & 0.279 & Pours slowly & No & No & $90 \mathrm{~min}$ & No & $14726 * *$ & 19173 \\
\hline S1-6X6 * & MK & $6 \mathrm{M} \mathrm{Na}$ & $11 / 22 / 10$ & 0.298 & Spatula required & No & No & $115 \mathrm{~min}$ & No & 10561 & 12832 \\
\hline S1-8X1R2 & MK & $8 \mathrm{M} \mathrm{Na}$ & $11 / 29 / 10$ & 0.312 & Spatula required & No & No & $75 \mathrm{~min}$ & No & 11082 & 12485 \\
\hline S1-8X2R1 & FS & $8 \mathrm{M} \mathrm{Na}$ & $11 / 29 / 10$ & 0.291 & Pours slowly & No & No & $120 \mathrm{~min}$ & No & 10213 & 15131 \\
\hline
\end{tabular}

* 8-12 ml high range water reducer (ADVA 140M) per $1 \mathrm{~kg}$ geopolymer material was added to the paste

** Measured on 21 day sample 
Table 5.3. Recipe for the Preparation of 55 gallons of the Recommended DuraLith Formulation (in g).

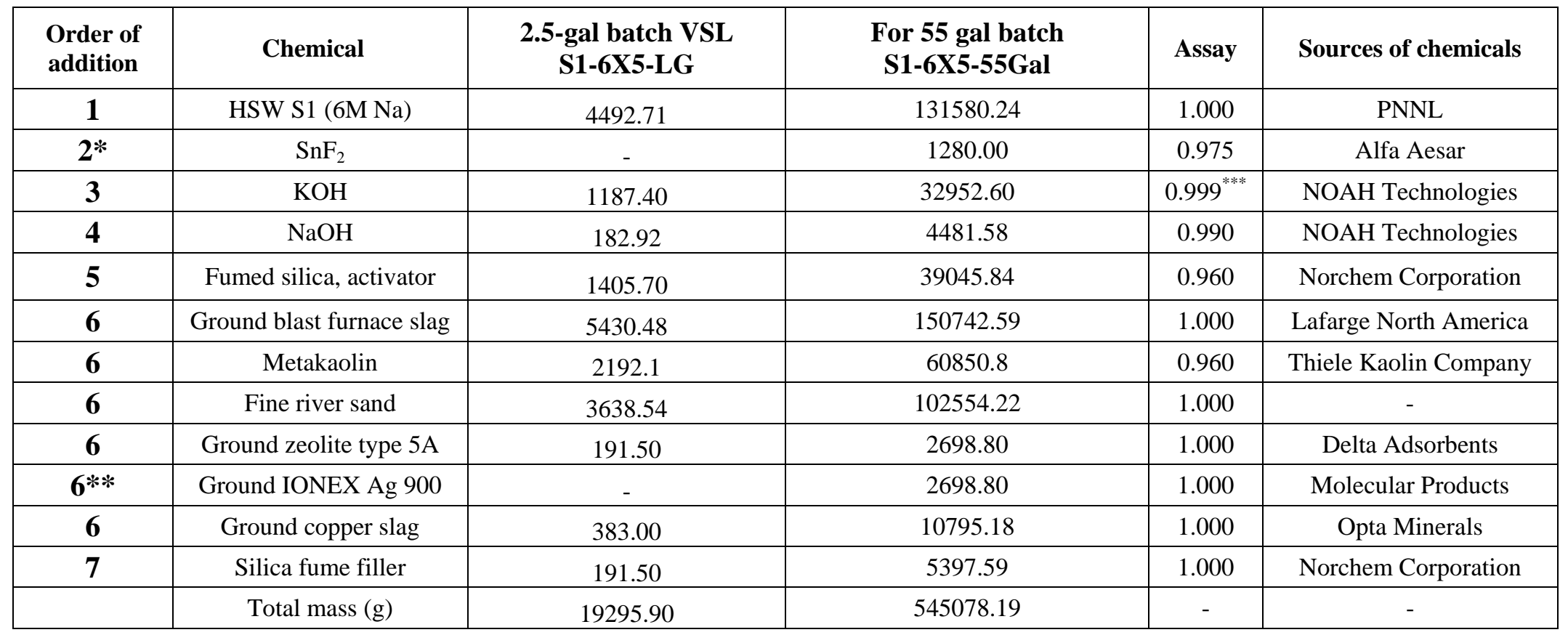

*Can be deleted in a technical-scale feasibility test, if cost is a concern

** Can be replaced by the same amount of ground zeolite type $5 \mathrm{~A}$ in the technical-scale feasibility test, if cost is a concern

*** Assay is on a metals basis; may vary depending on water content. 


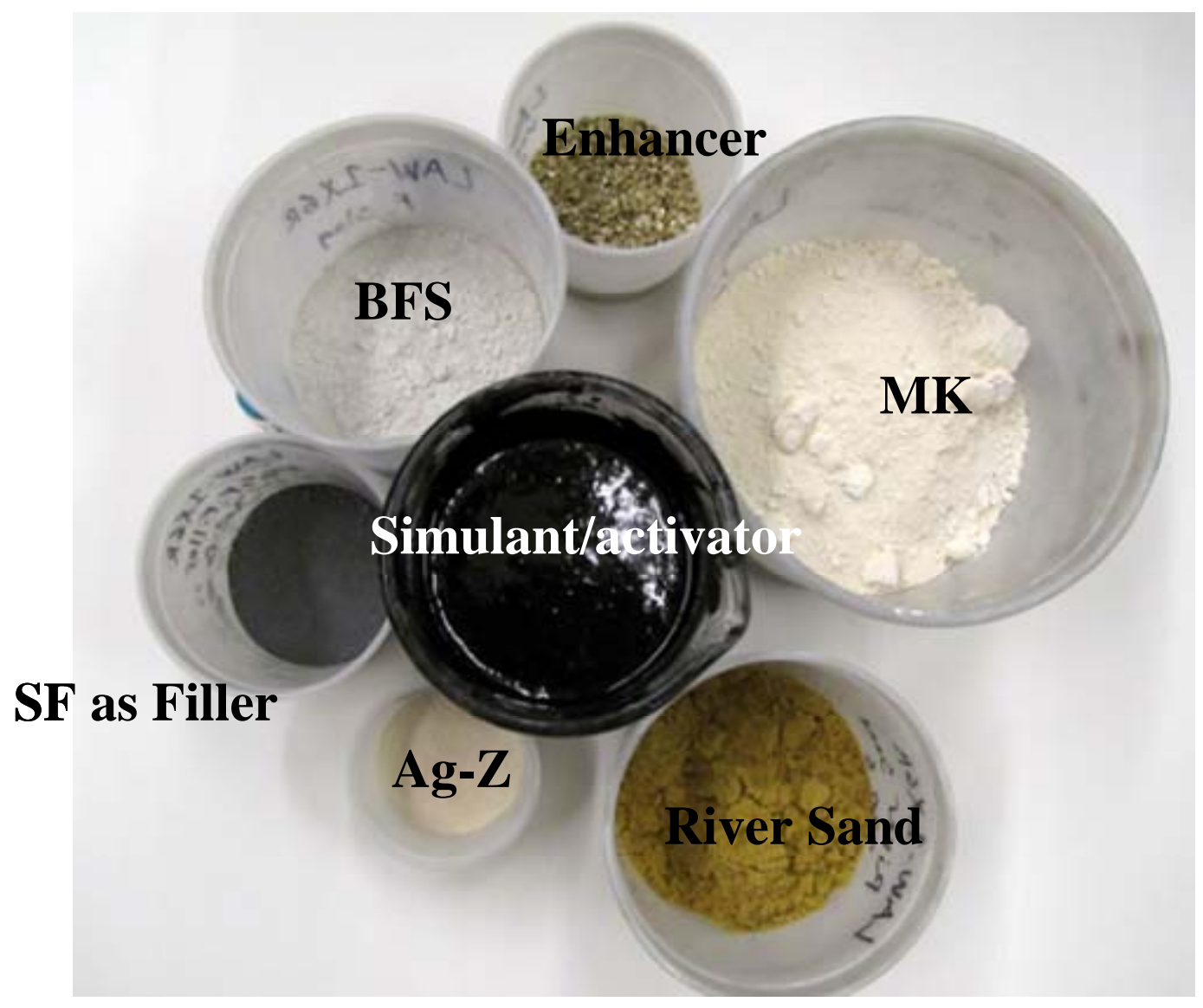

Figure 4.1. Ingredients for the preparation of a DuraLith product. 


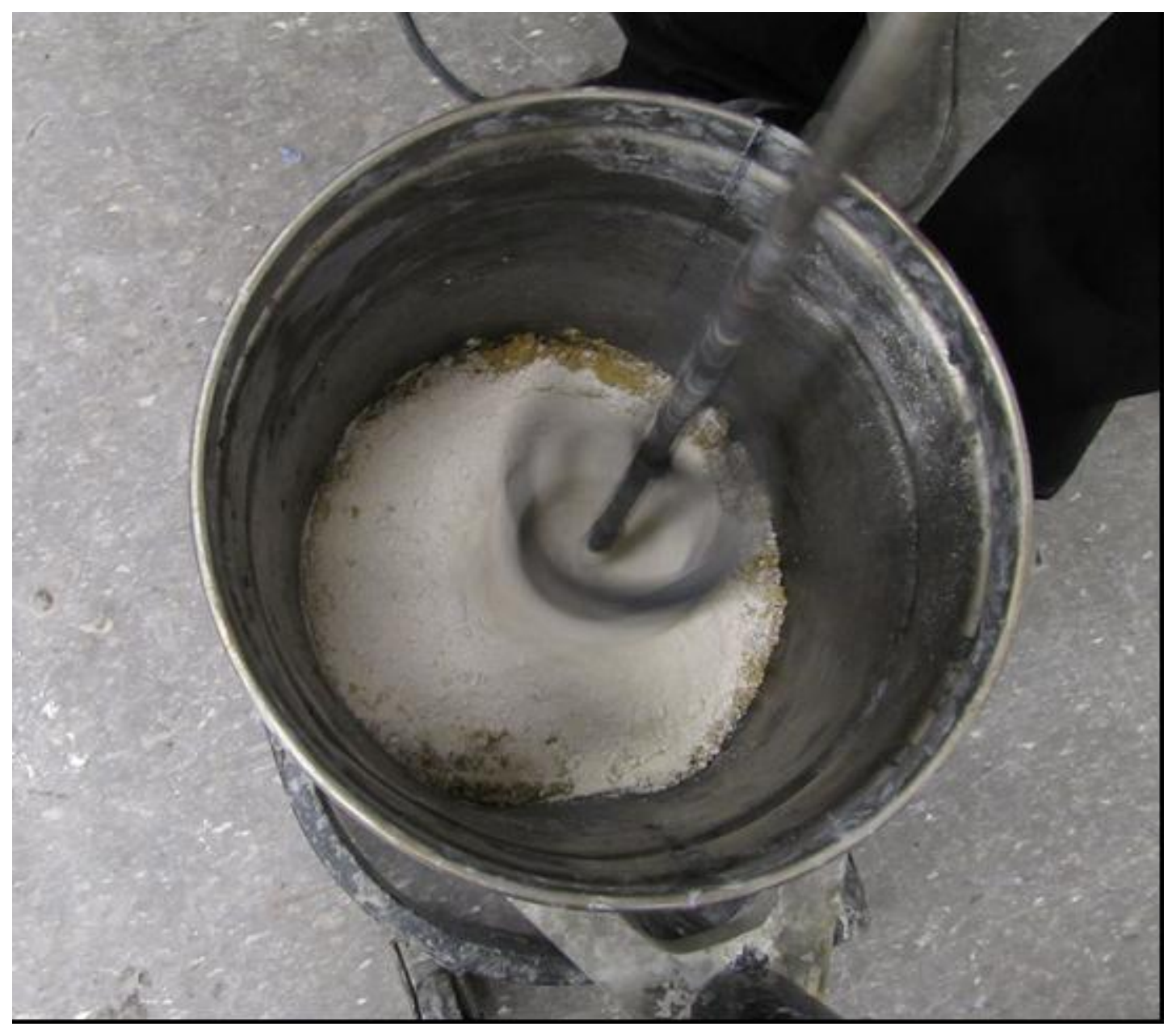

Figure 4.2. Mixing the dry ingredients with a hand-held mixer (EHR23). 


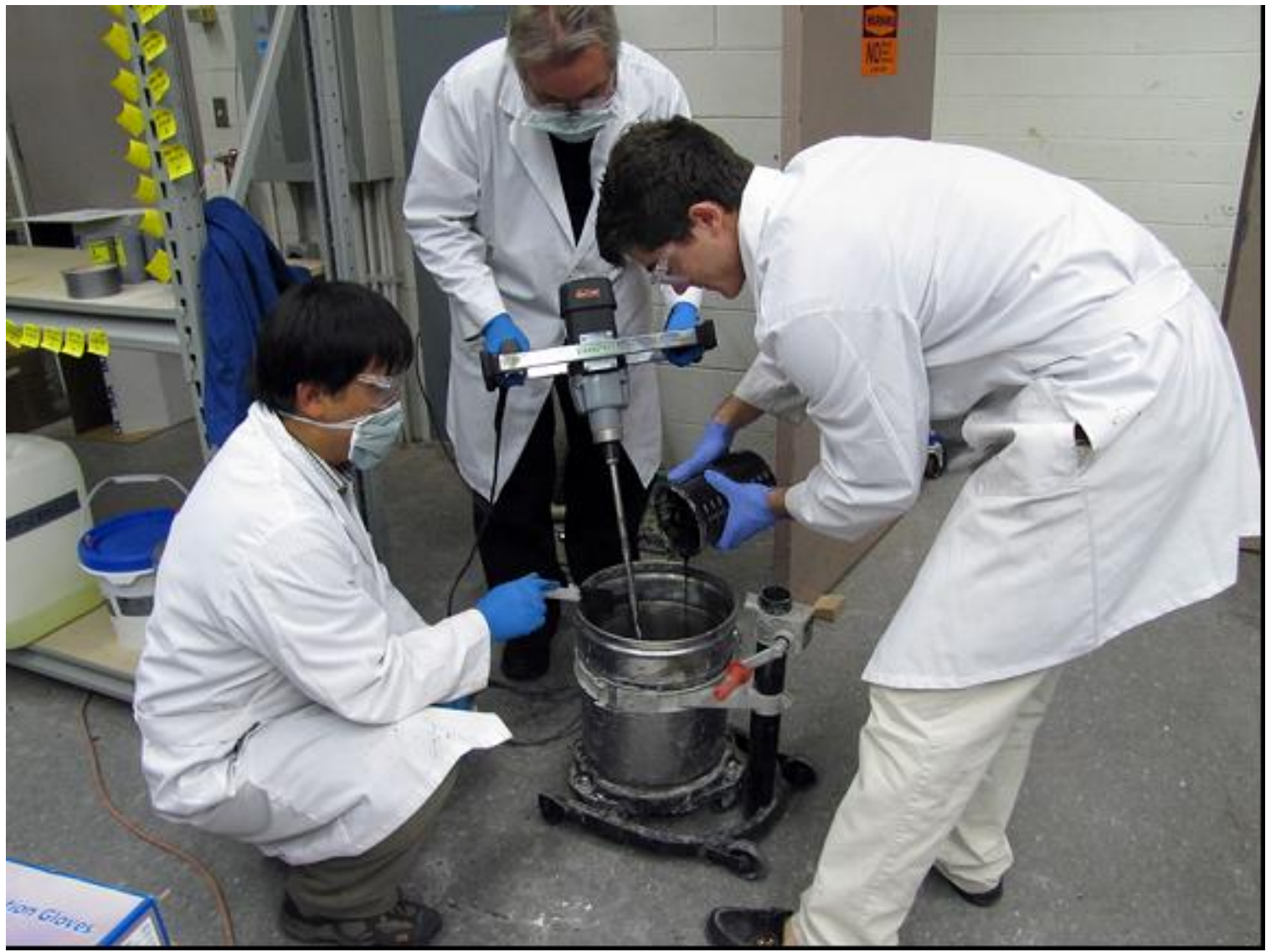

Figure 4.3. Pouring the activator solution into the dry binder mix. 


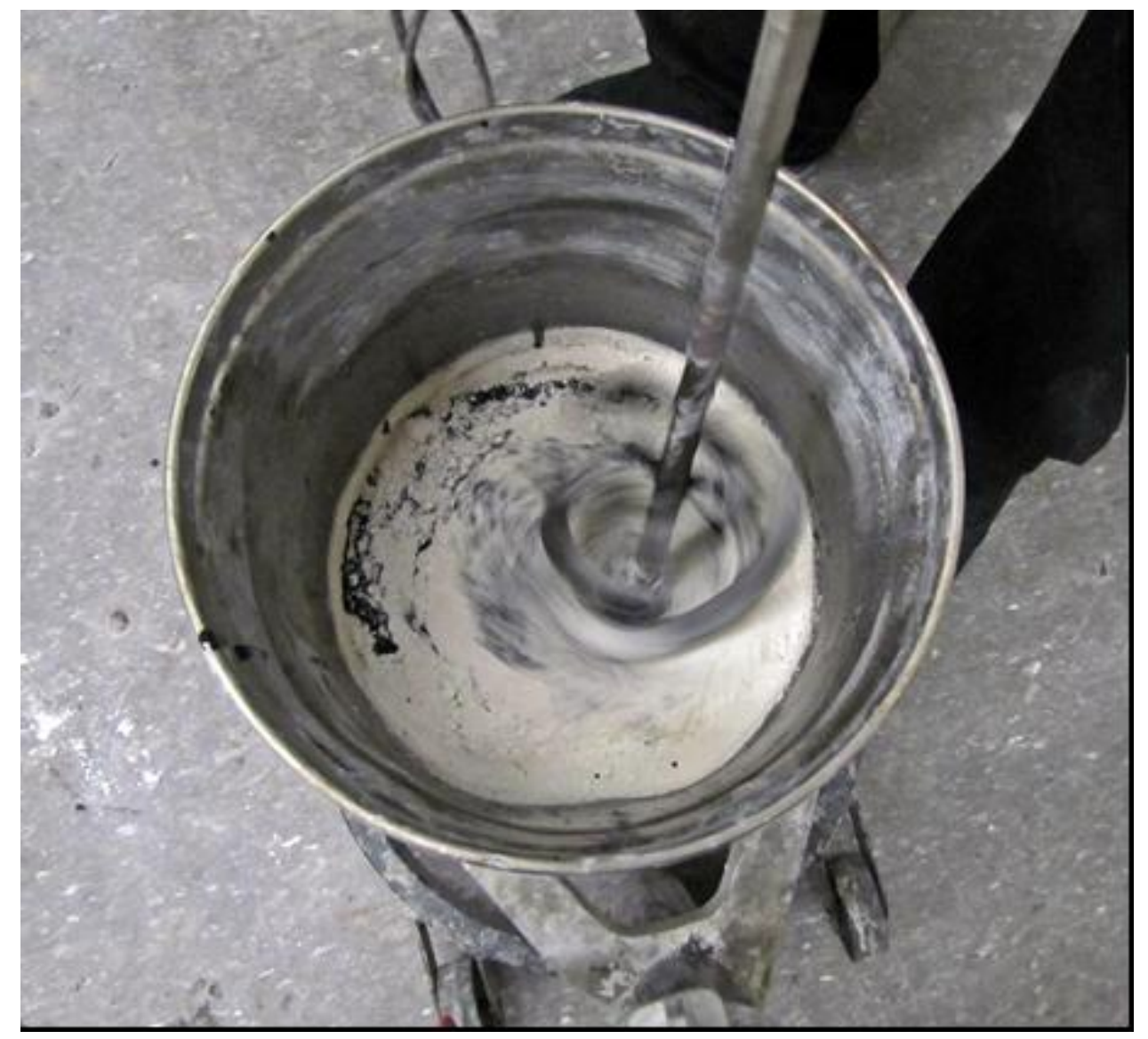

Figure 4.4. Early stage of mixing binder and activator. 


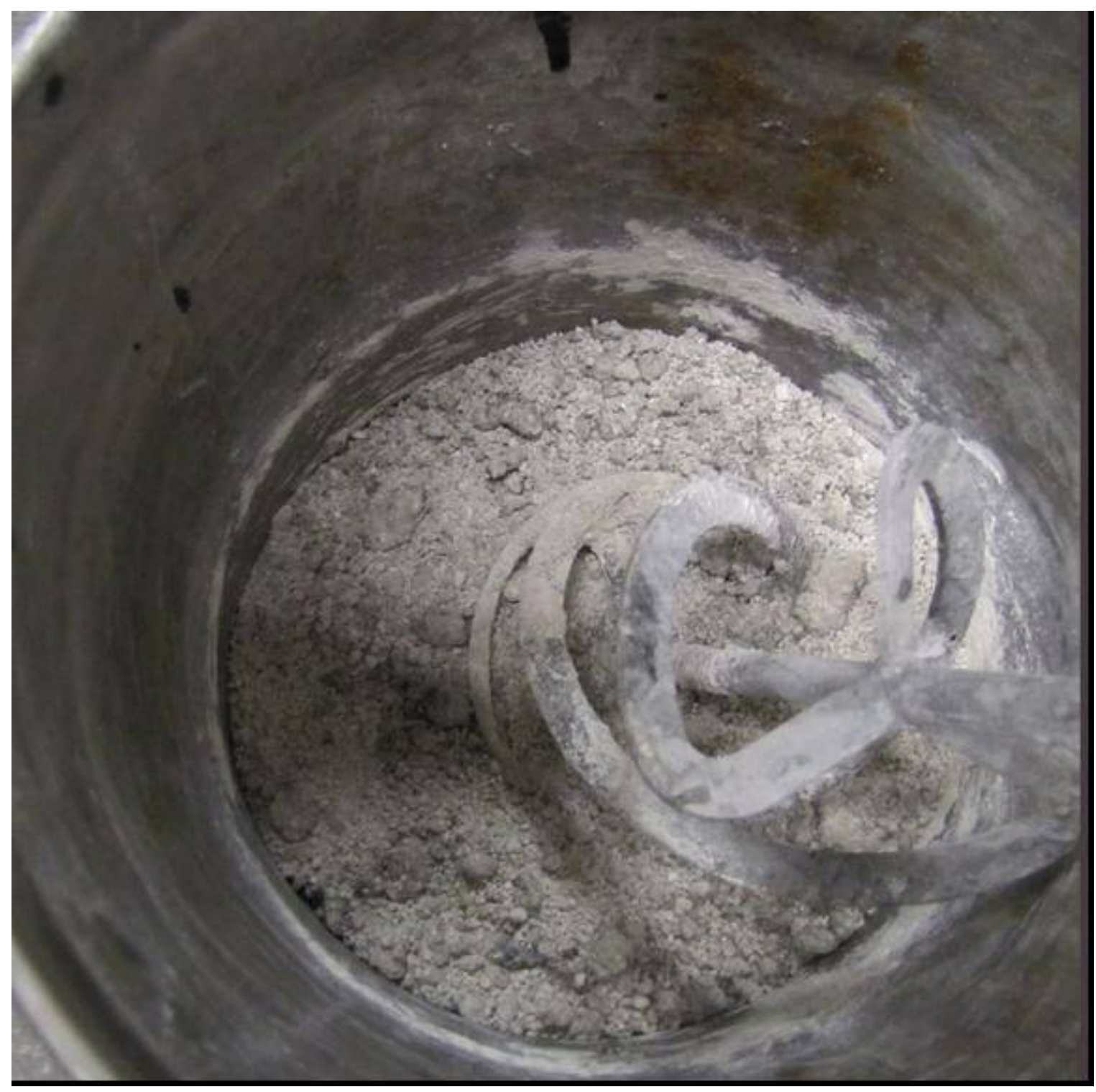

Figure 4.5. After a few minutes the mix becomes fairly dry. 


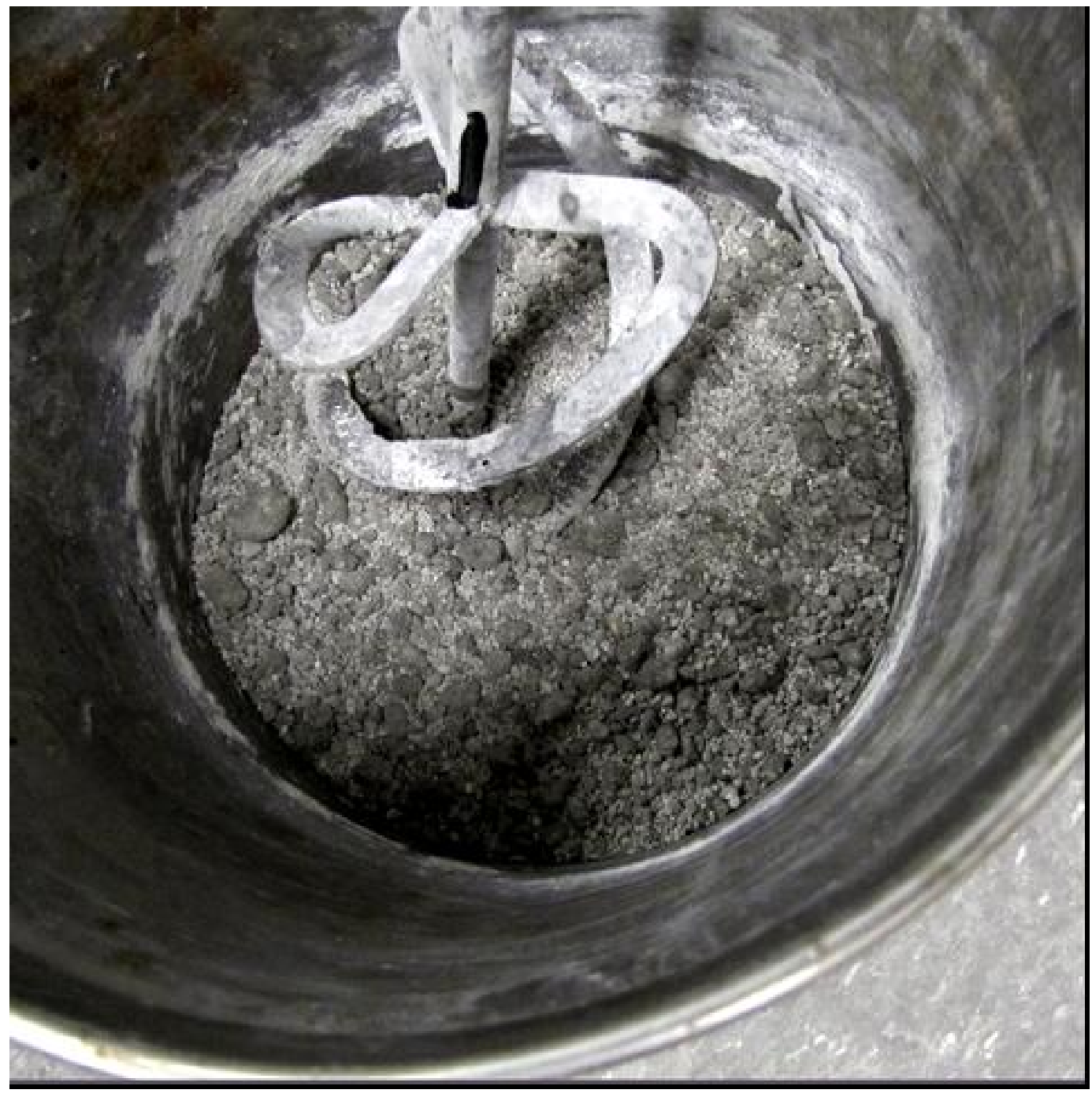

Figure 4.6. The dryness of the mix begins to disappear after two minutes. 


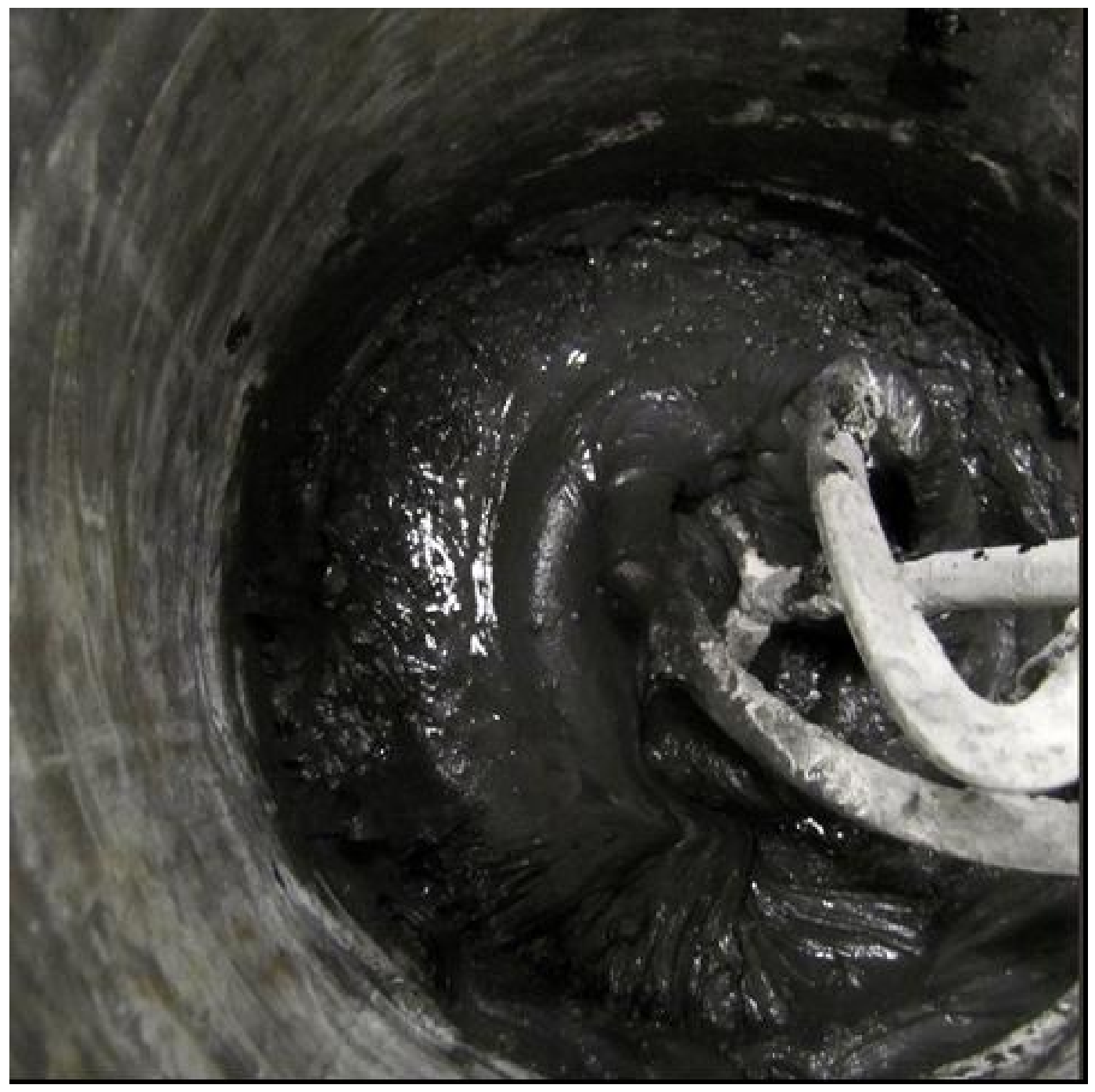

Figure 4.7. Within about three minutes the paste becomes homogeneous. 


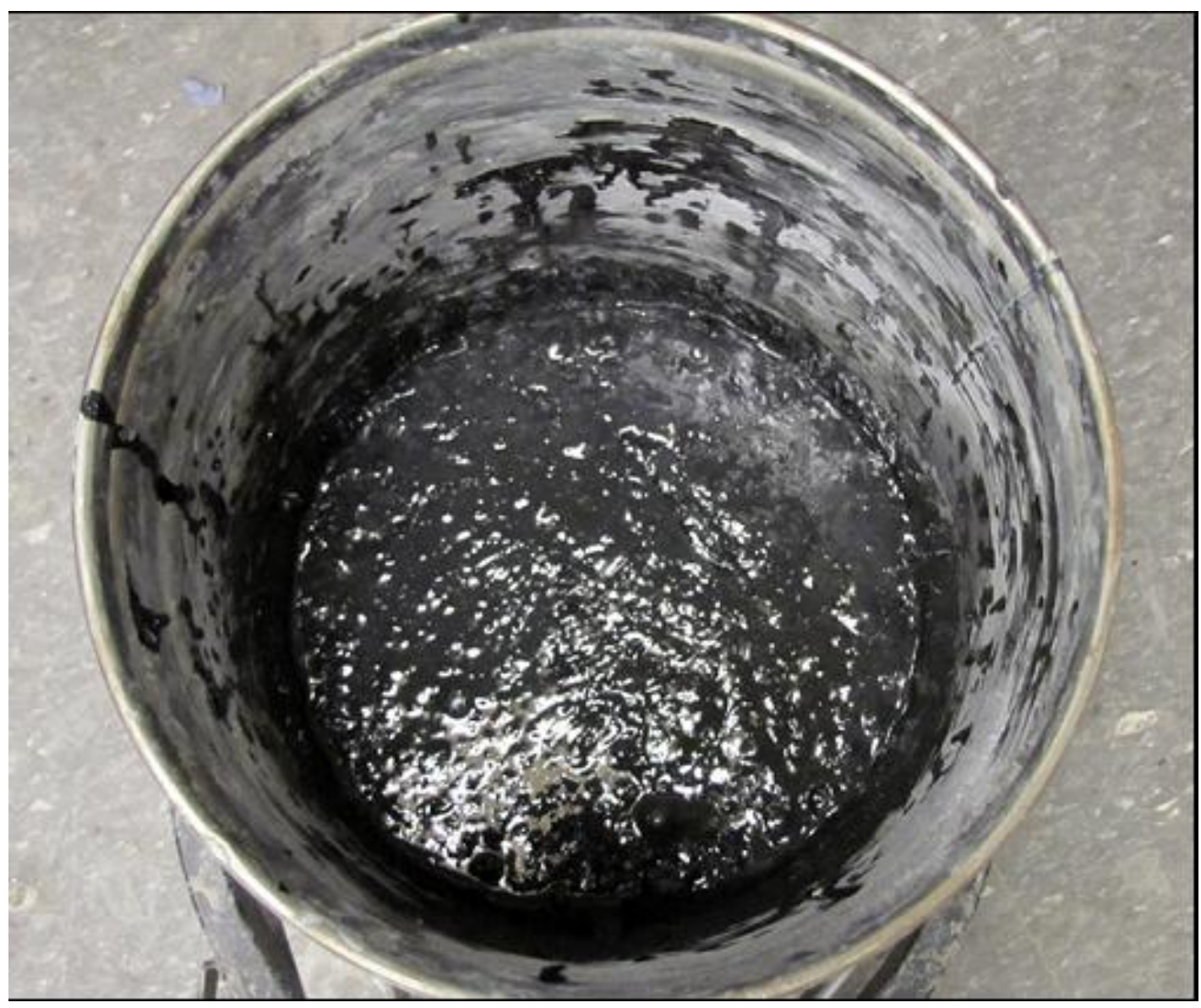

Figure 4.8. The paste is free of lumps and ready to pour. 


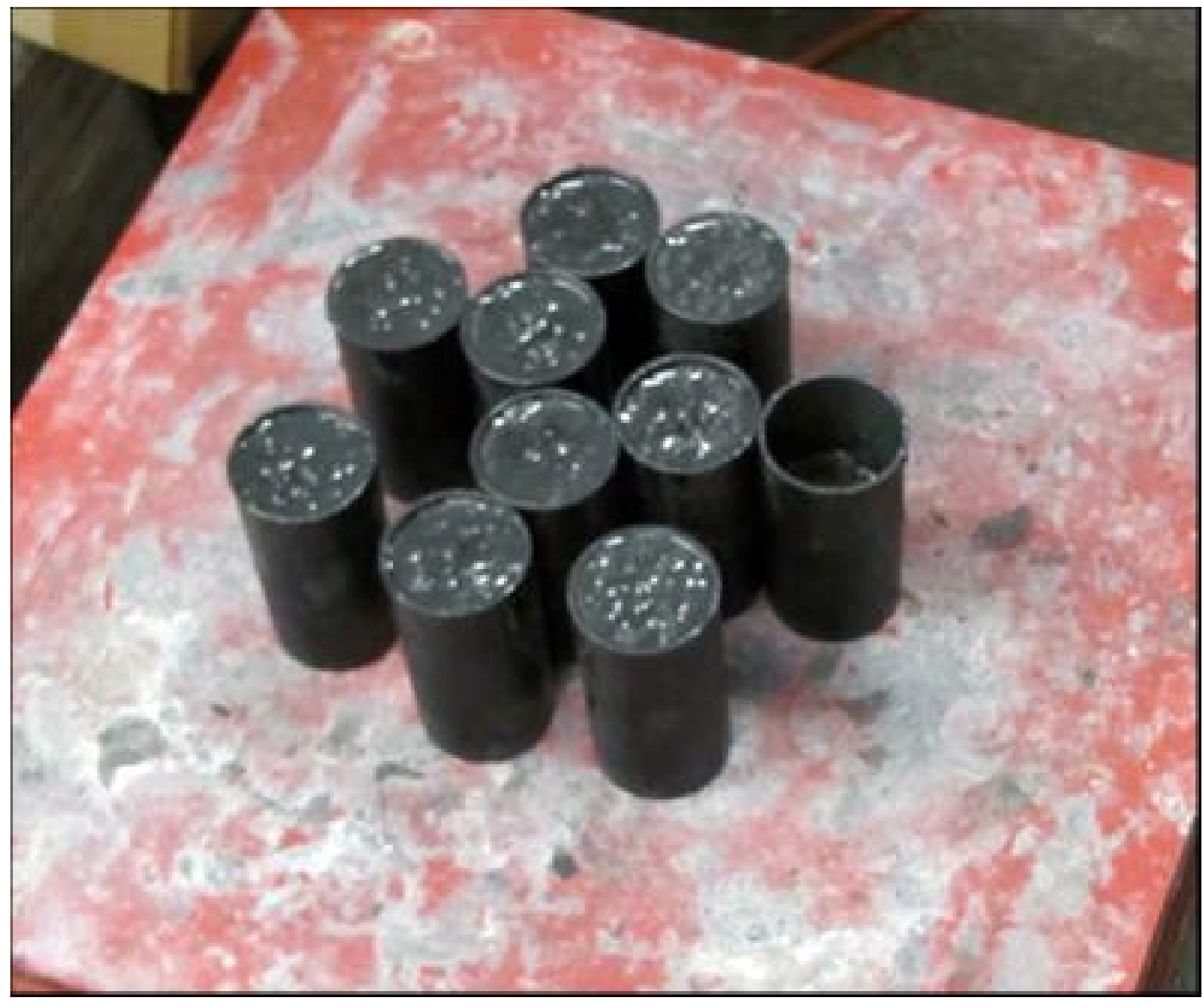

Figure 4.9. Fresh paste in 2" by 4 " plastic moulds on a vibrating table. 


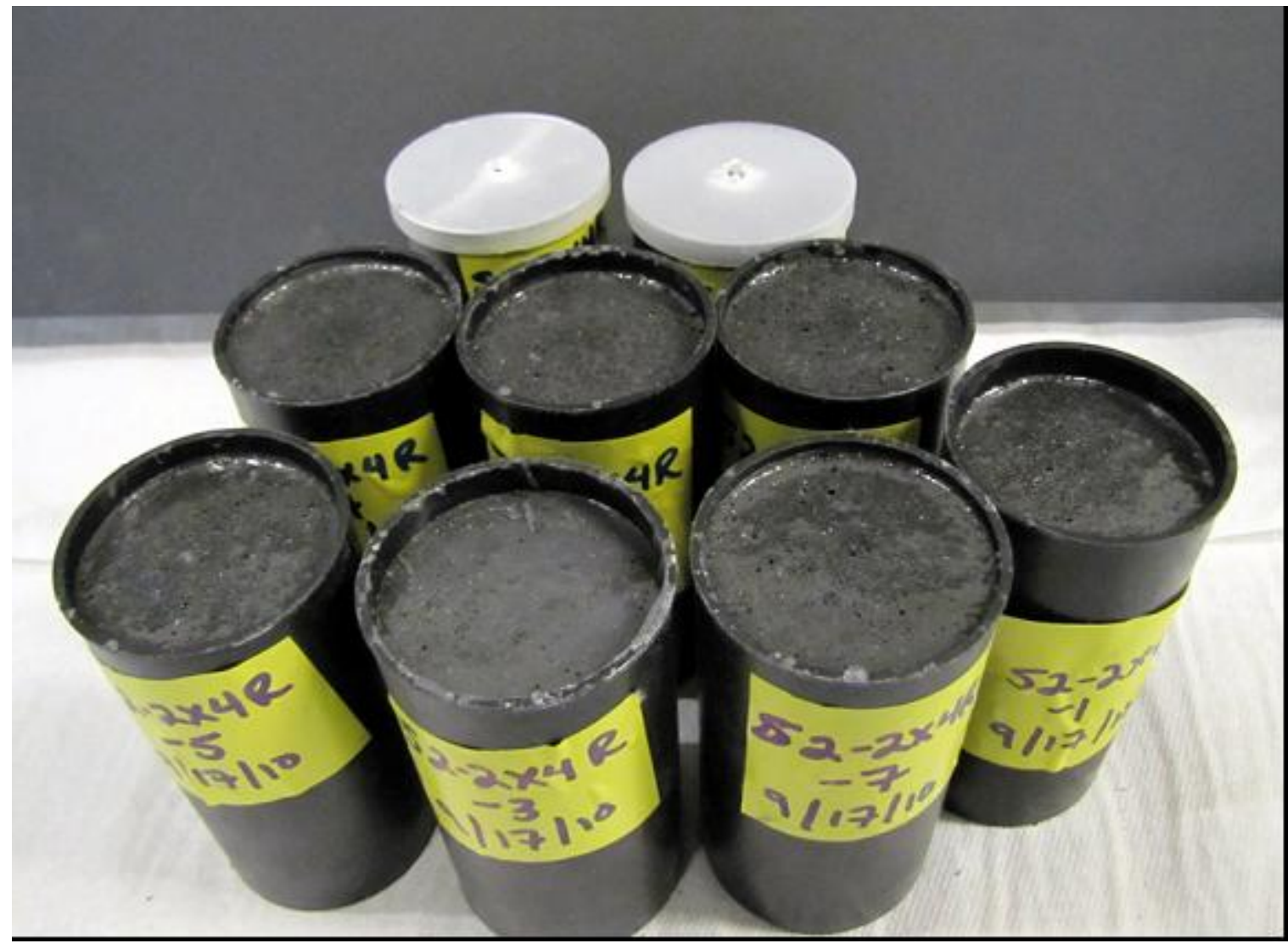

Figure 4.10. Hardened DuraLith samples after 24 hours at room temperature. 


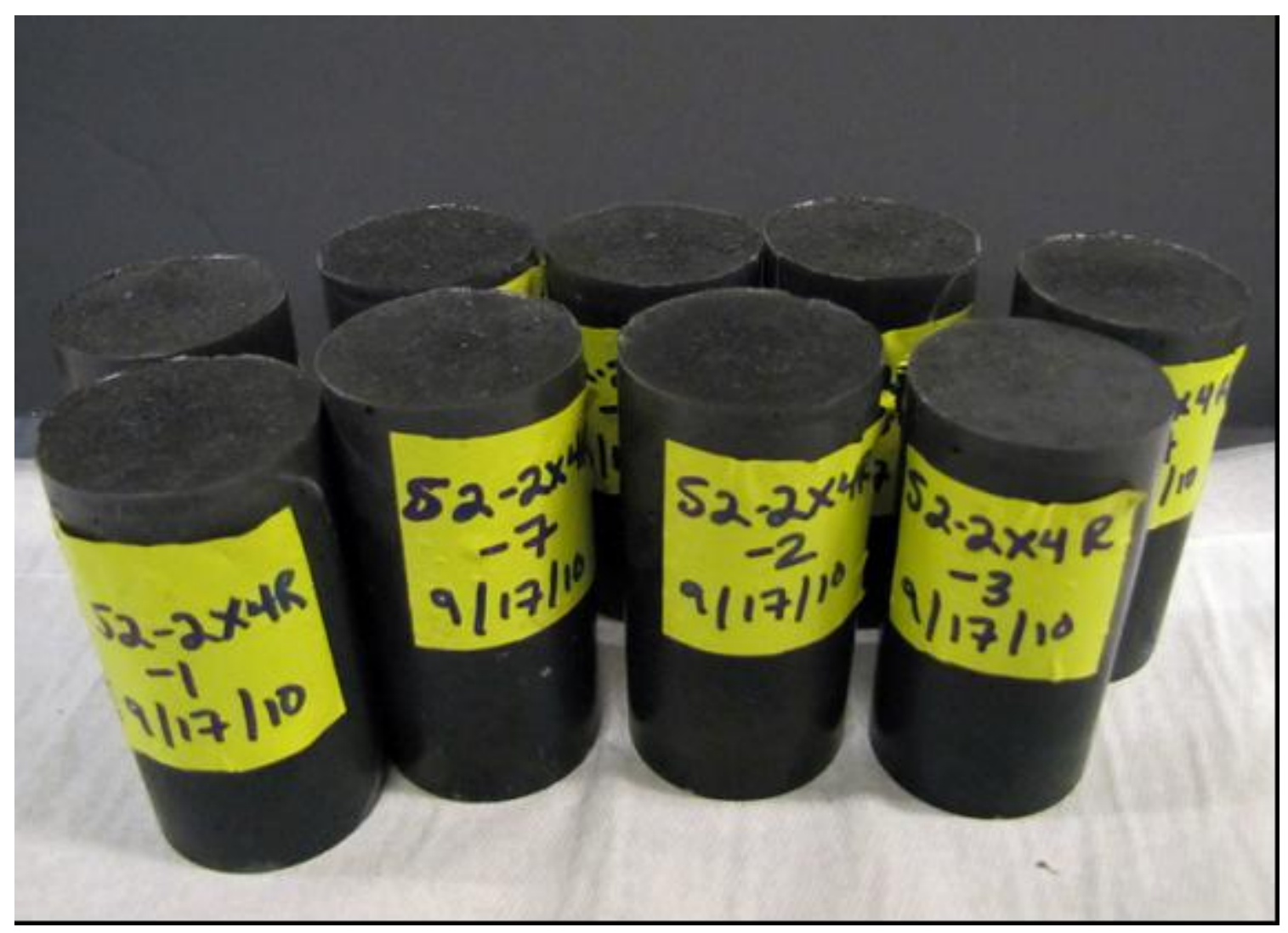

Figure 4.11. DuraLith samples after demoulding. 


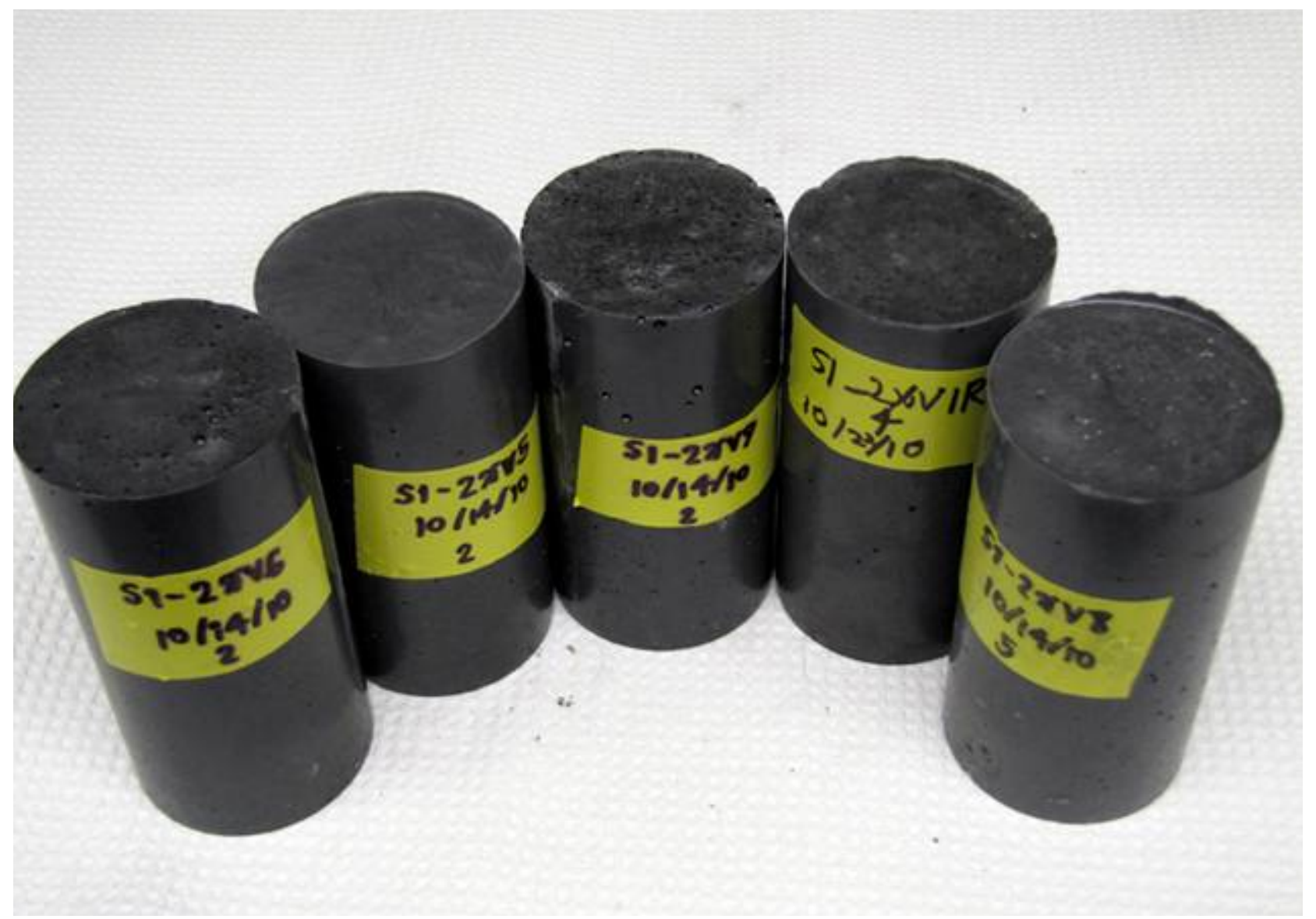

Figure 4.12. Air bubbles shown in sample surfaces. 


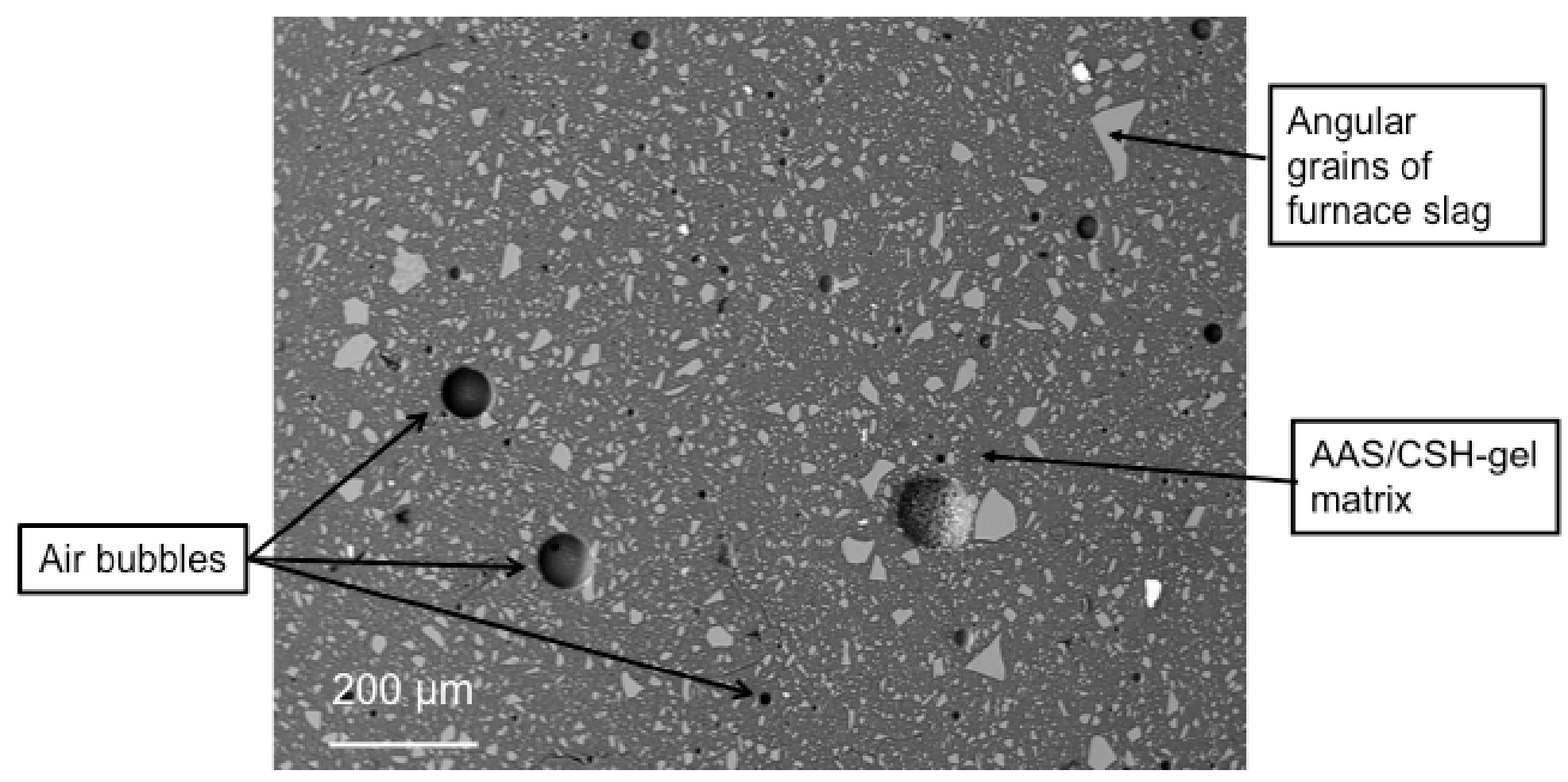

Figure 4.13. Air bubbles in a DuraLith sample (SEM micrograph).

(AAS = Alkali Alumino-Silicate, CHS = Calcium Silicat Hydrate) 


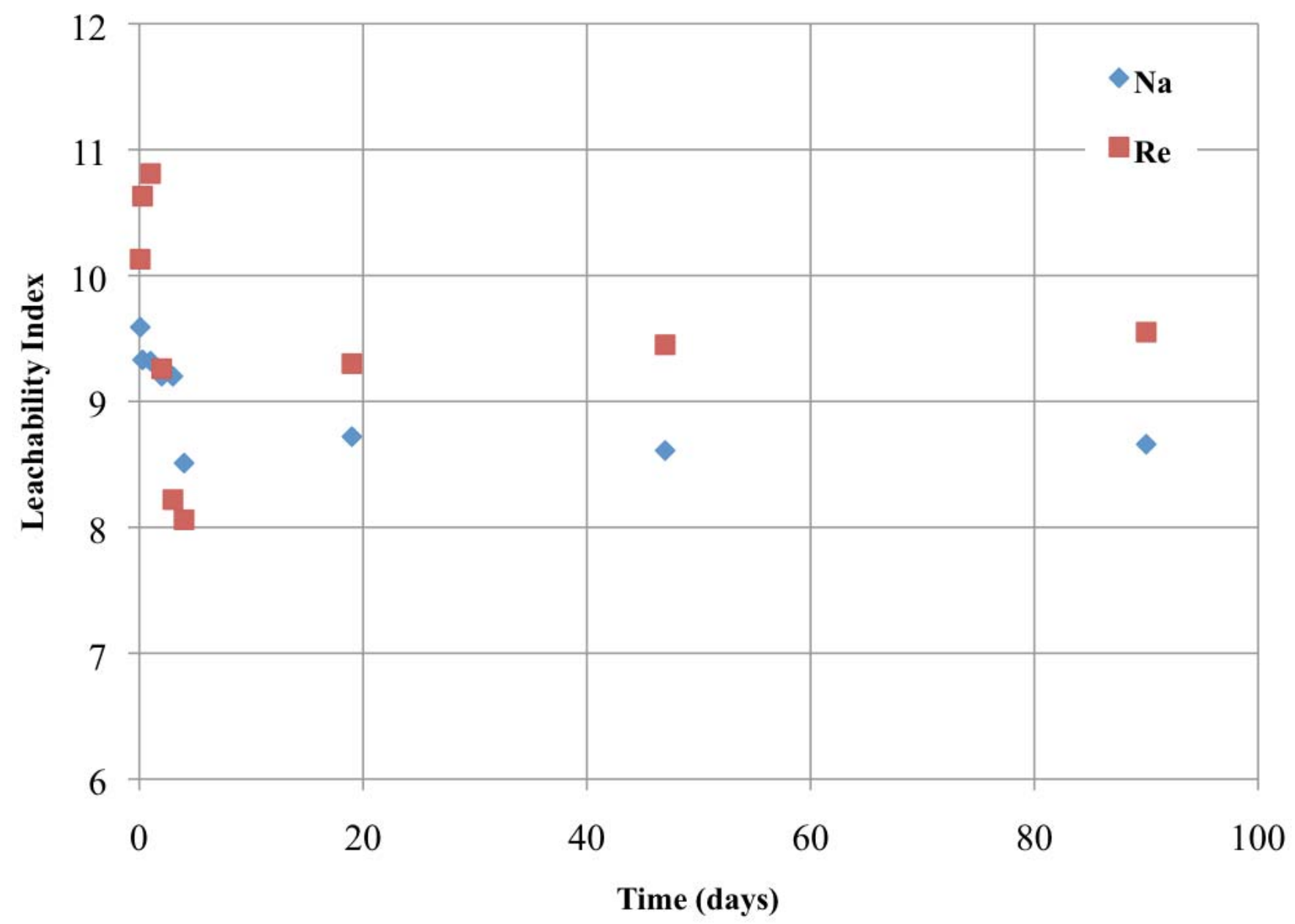

Figure 14a. Results of ANS 16.1 Leach Test for DuraLith Sample S1-2X13R2. 


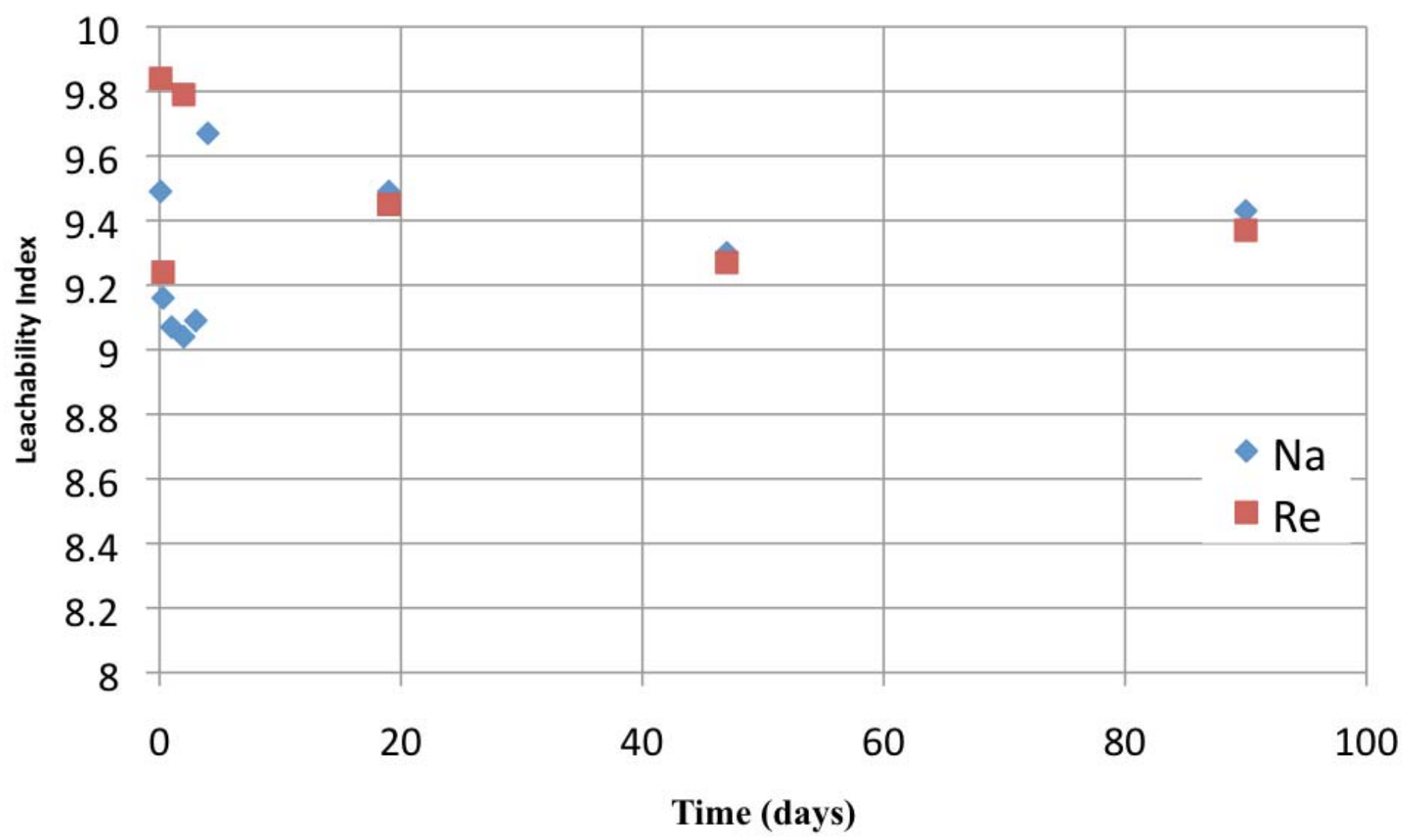

Figure 14b. Results of ANS 16.1 Leach Test DuraLith Sample S1-2X14. 


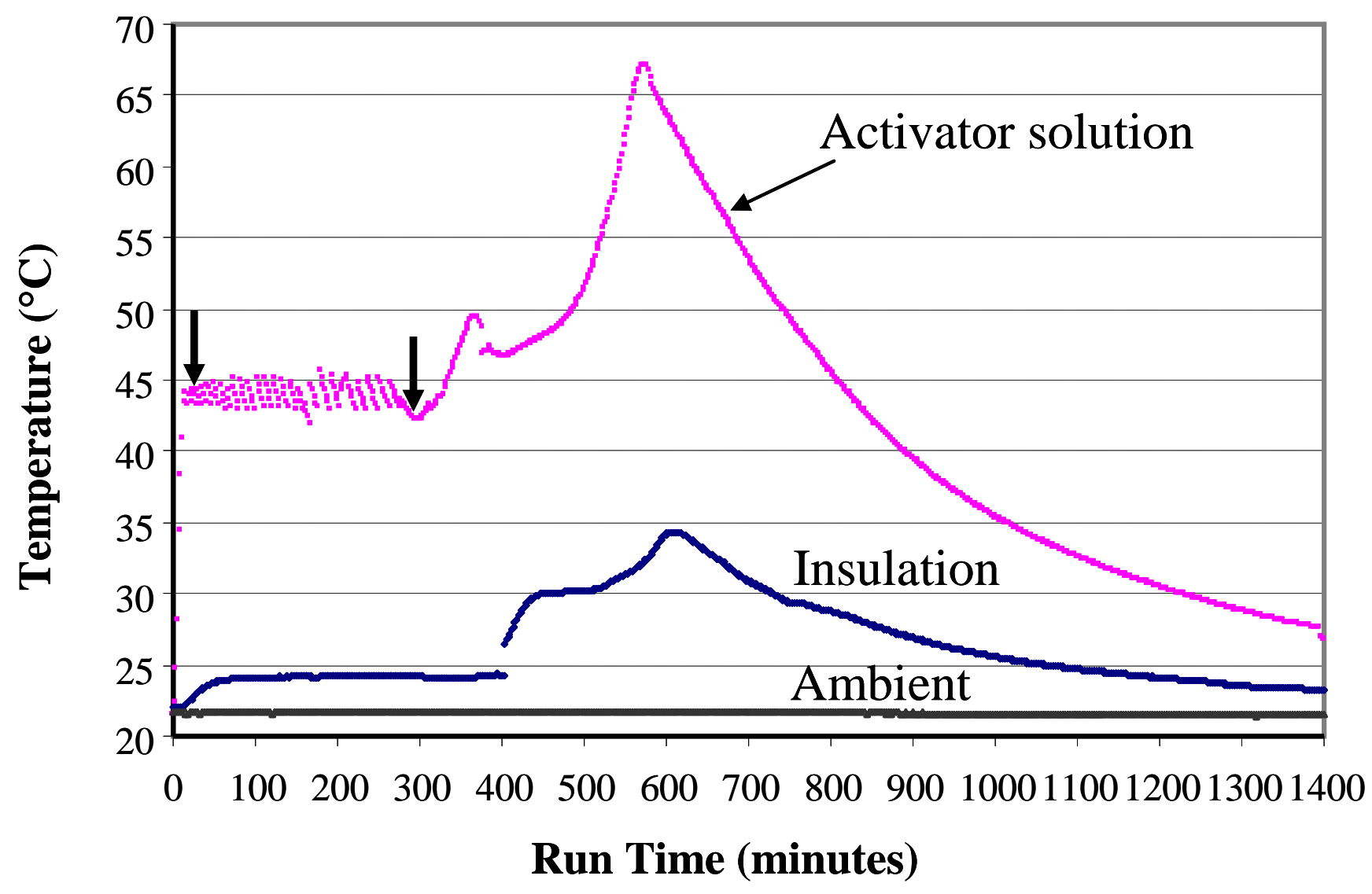

Figure 4.15. Heat generation in an activator solution (temperature curve). 


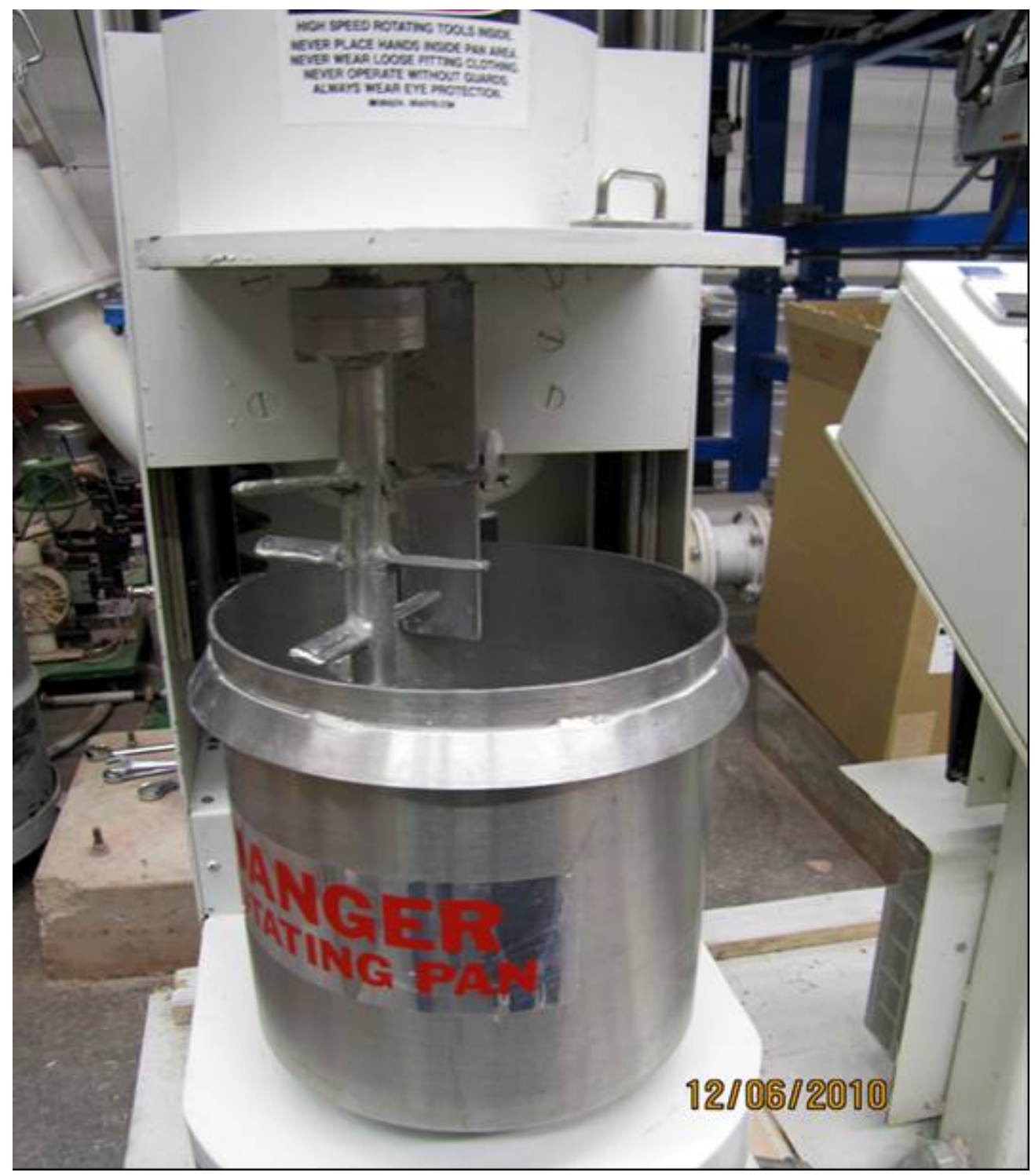

Figure 4.16. K-Lab intensive mixer from Lancaster Engineering (5-gal pan). 


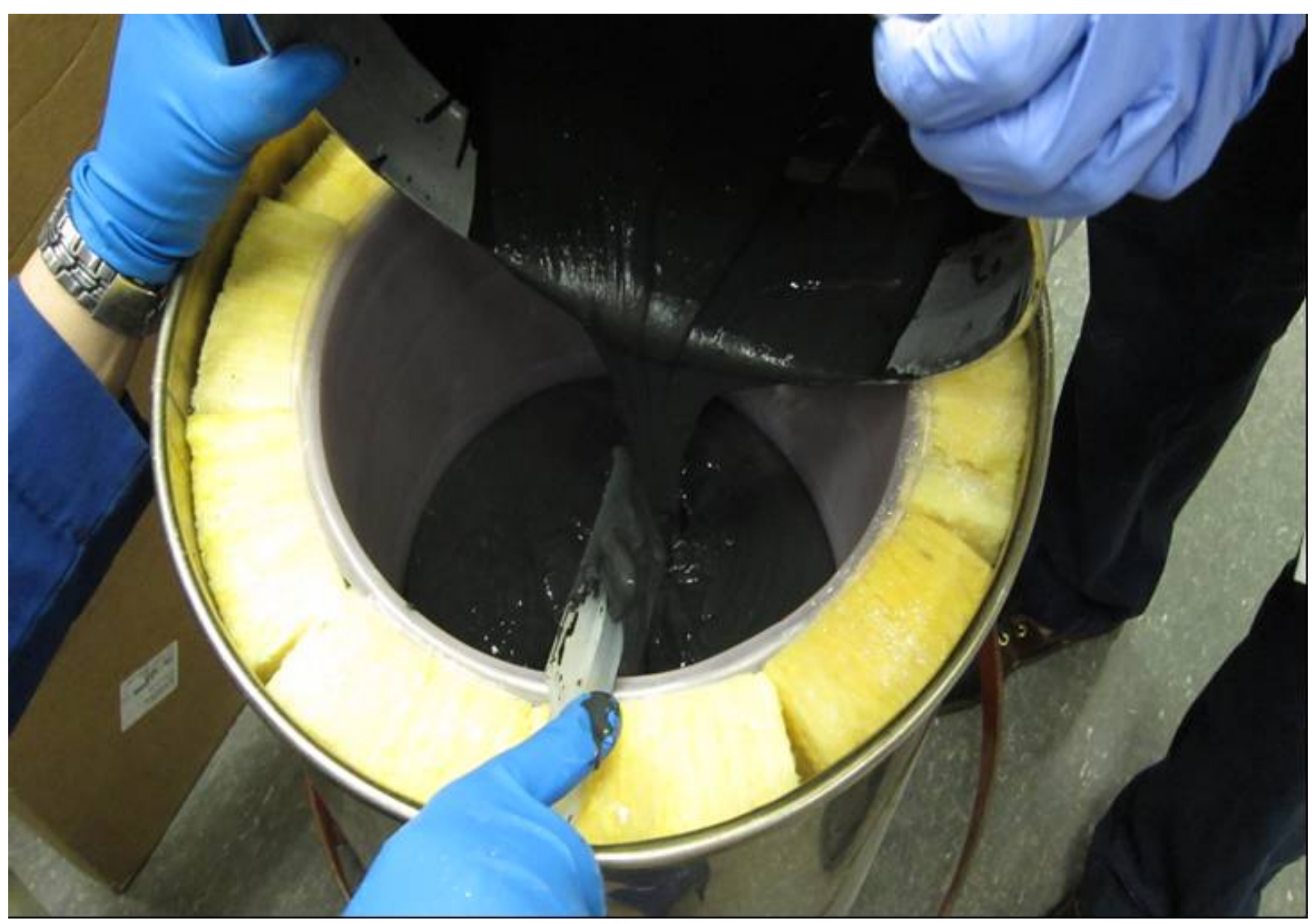

Figure 4.17. Pouring 2.5 gal Duralith paste. 


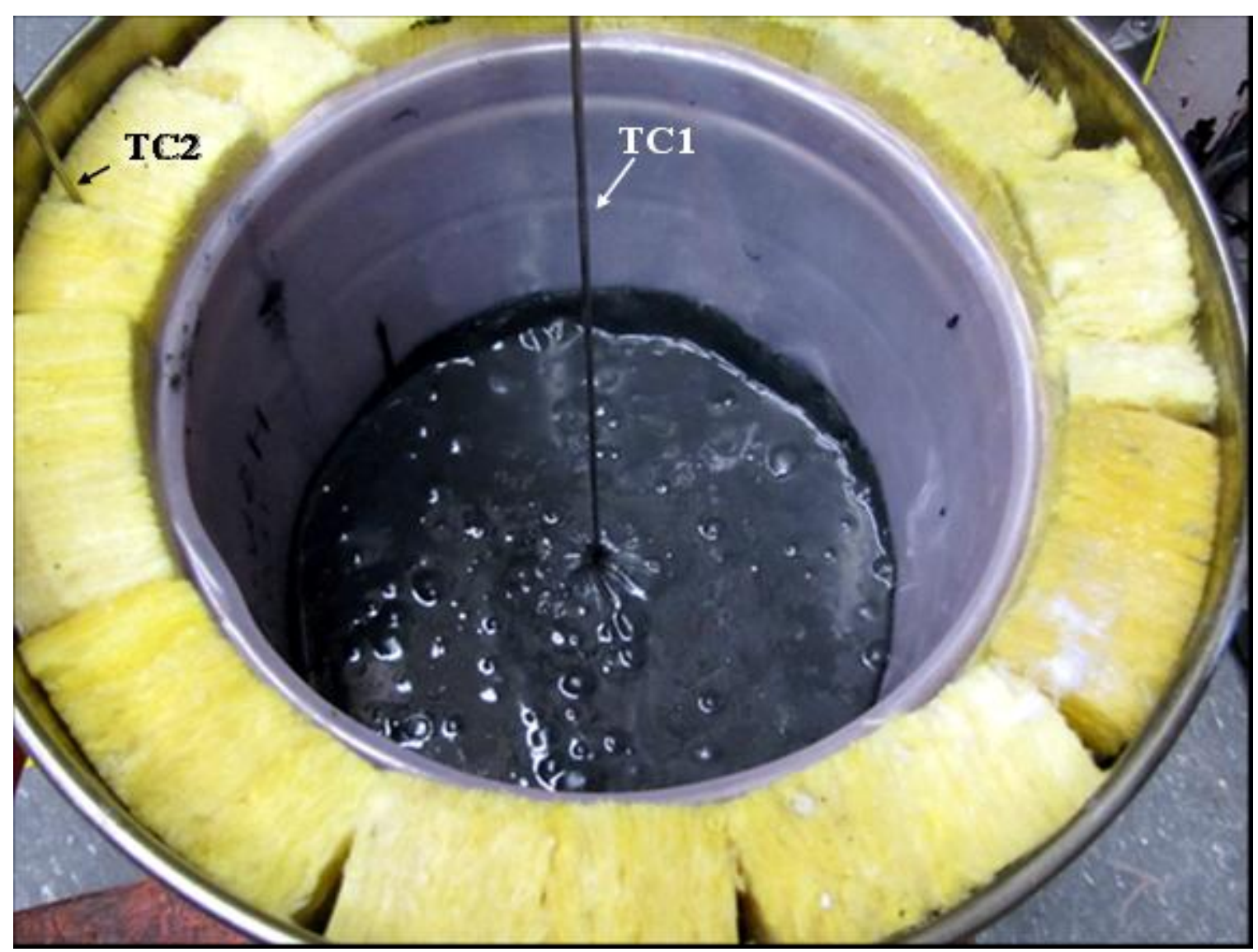

Figure 4.18. Container holds 2.5 gal fresh paste and thermocouples (middle and left) for temperature measurement during curing. 


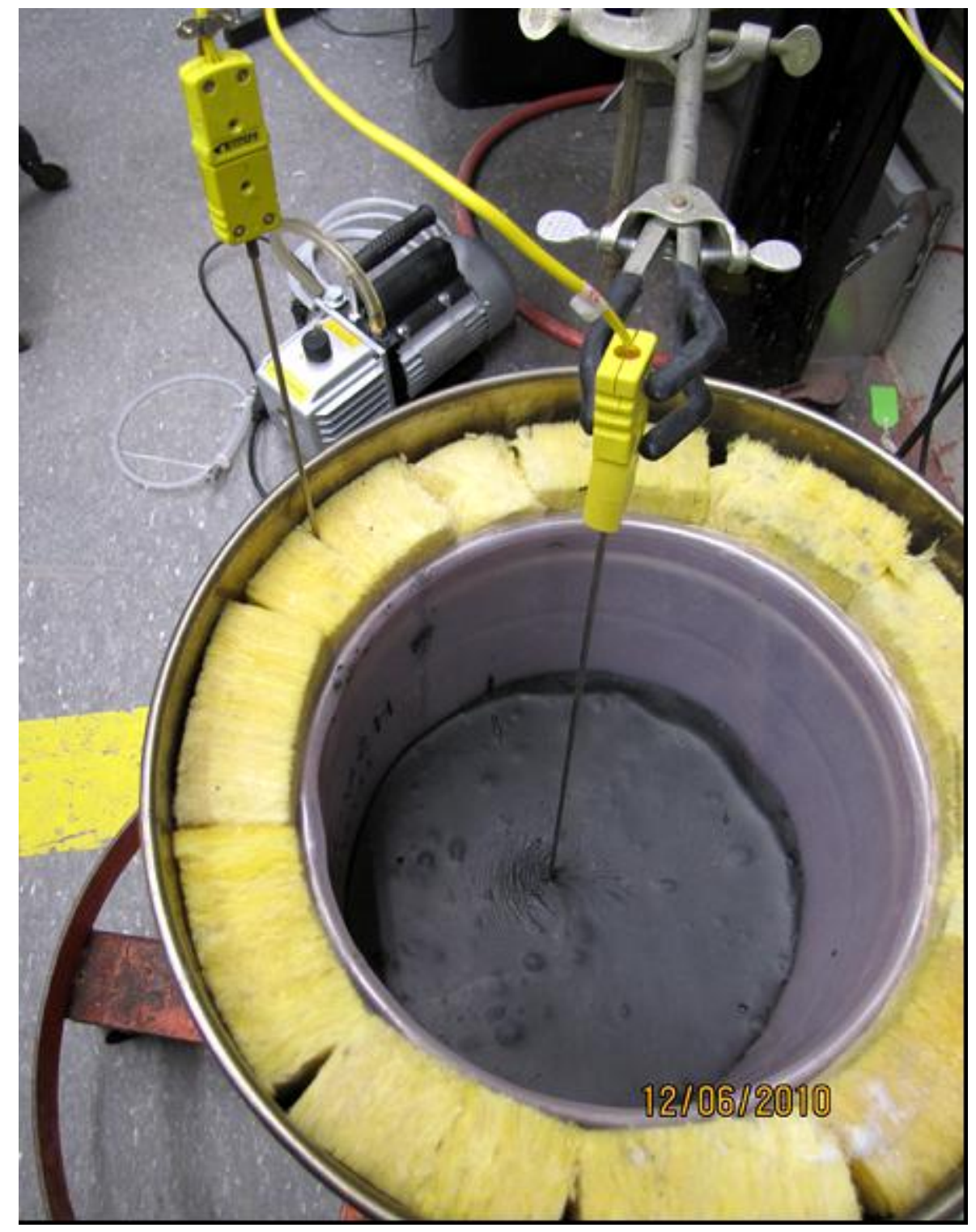

Figure 4.19. Container with 2.5 gal of hardened crack-free paste. 


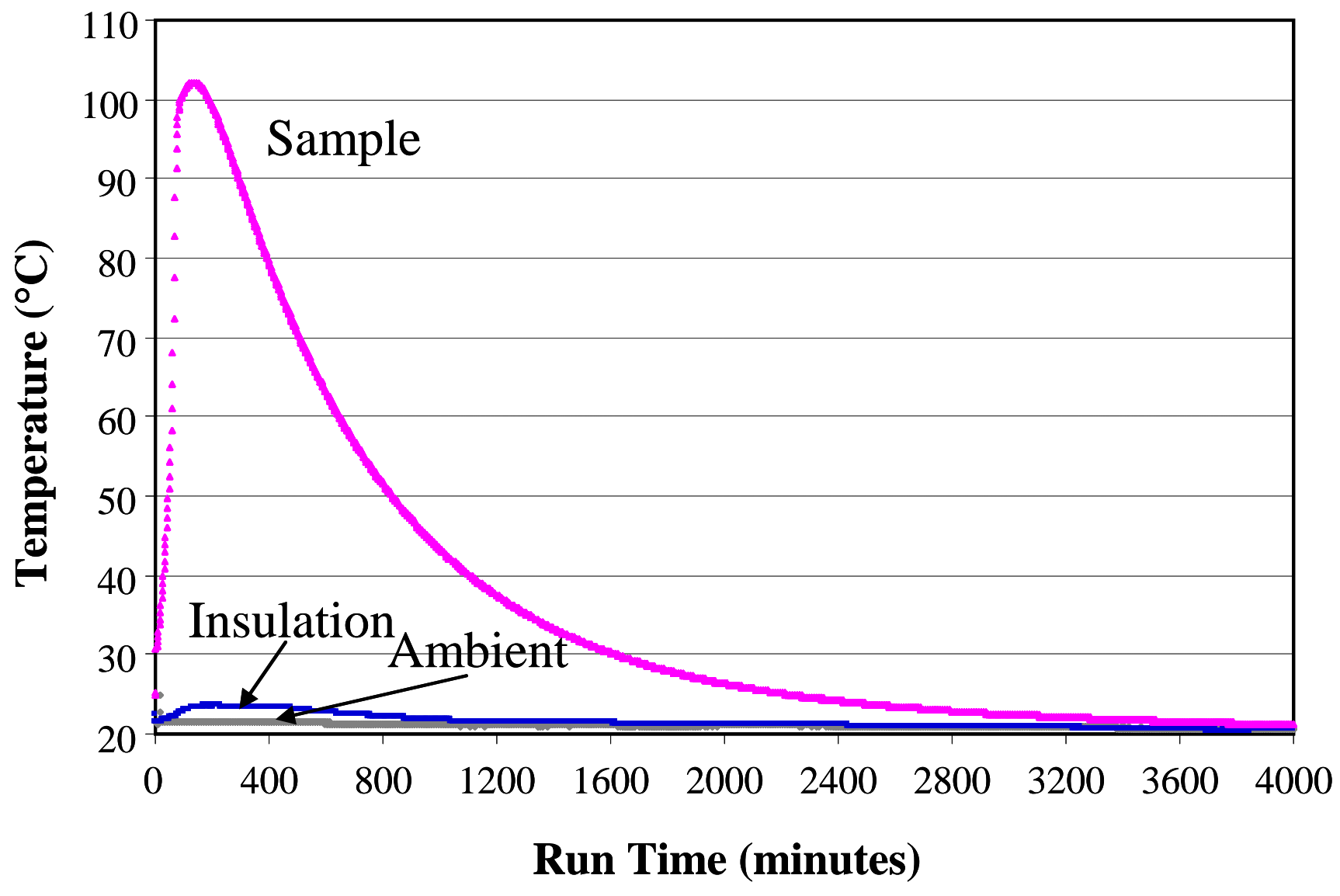

Figure 4.20a. Heat generation in a furnace slag-based paste (temperature curve). 


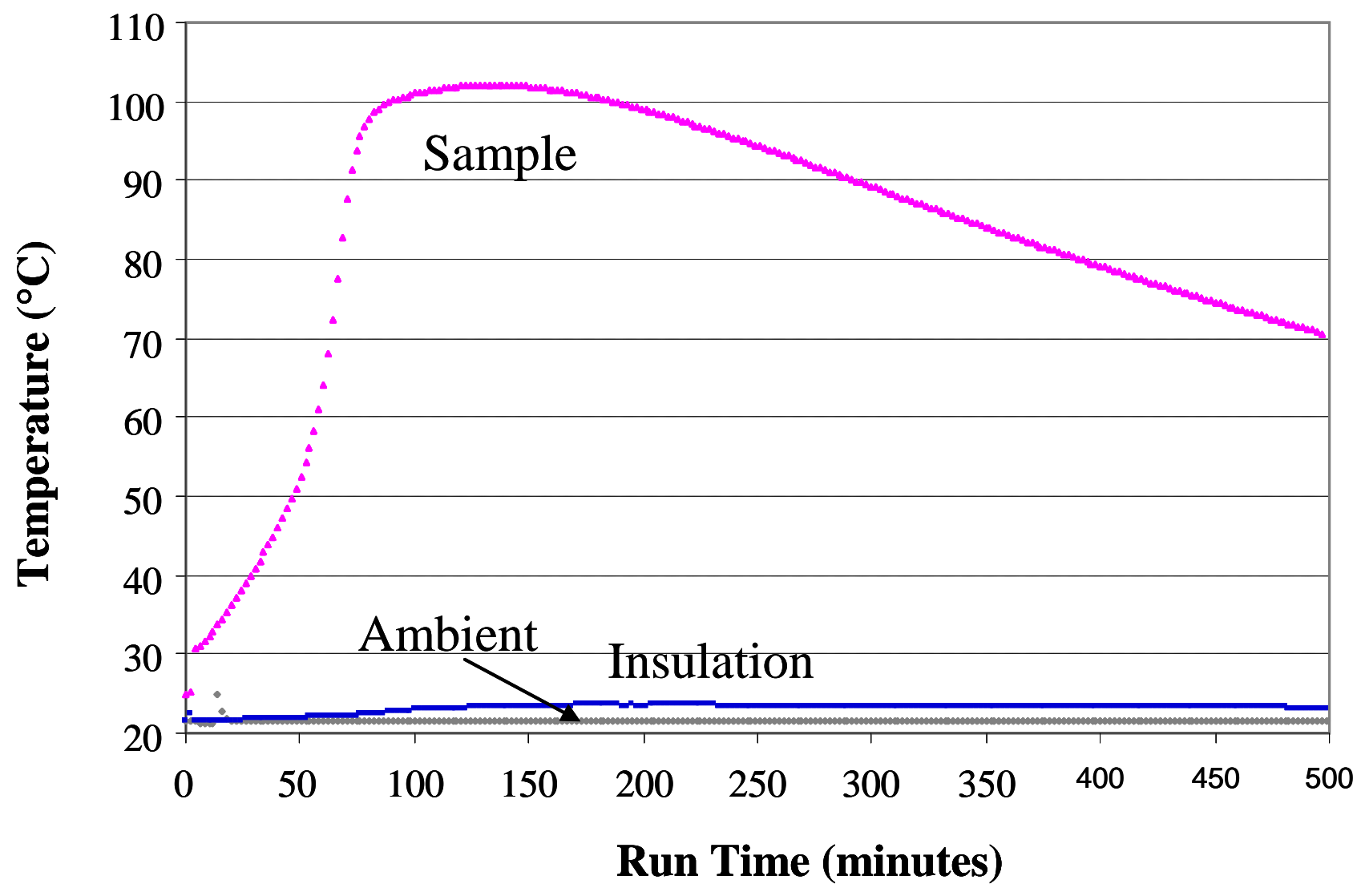

Figure 4.20b. Heat generation in a furnace slag-based paste; first 500 minutes (temperature curve). 


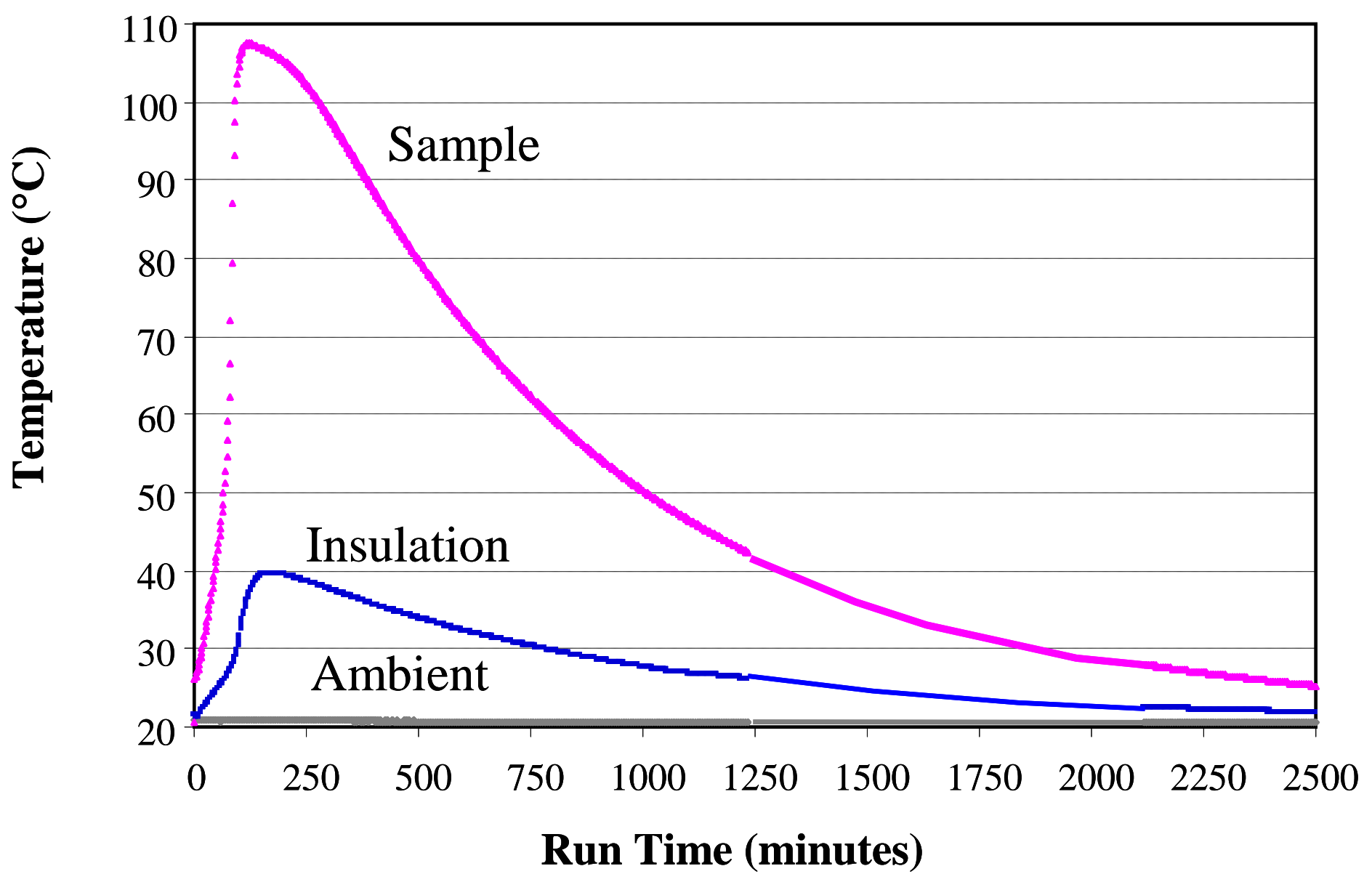

Figure 4.21a. Heat generation in a metakaolin-based paste (temperature curve). 


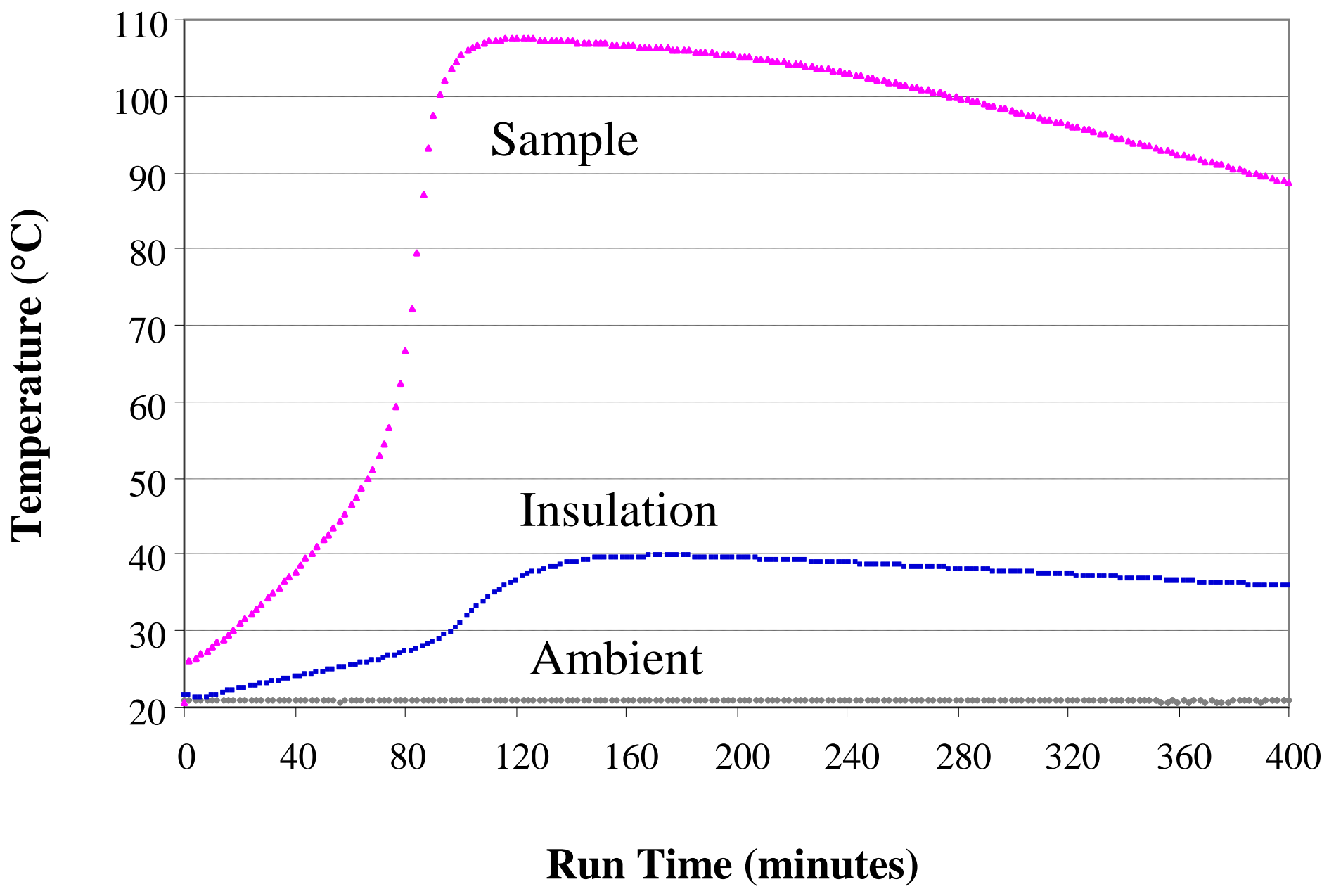

Figure 4.21b. Heat generation in a metakaolin-based paste; first 400 minutes (temperature curve). 


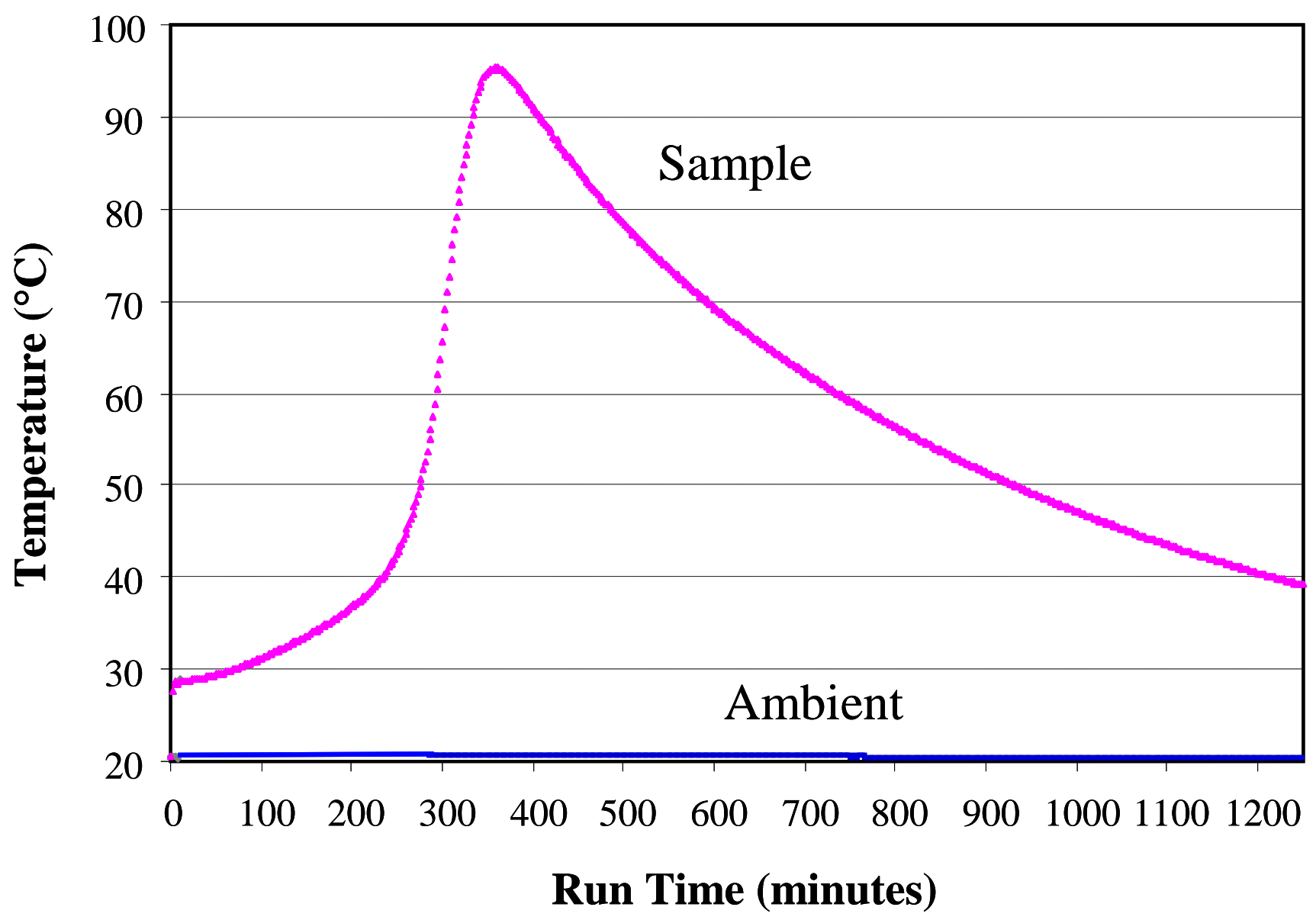

Figure 4.22. Heat generation in a furnace slag based paste with 6M Na S1 simulant (temperature curve). 